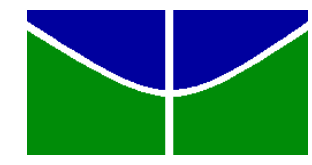

UNIVERSIDADE DE BRASÍLIA

INSTITUTO DE LETRAS

DEPARTAMENTO DE LÍNGUAS ESTRANGEIRAS E TRADUÇÃO

PROGRAMA DE PÓS-GRADUAÇÃO EM LINGUÍSTICA APLICADA

O TRABALHO COM A ORALIDADE EM UM CURSO DE LICENCIATURA EM

LÍNGUA ESPANHOLA (EAD): REALIDADES E NECESSIDADES

LUCIANA BRANDÃO DOURADO

Brasília - DF

2016 
UNIVERSIDADE DE BRASÍLIA

INSTITUTO DE LETRAS

DEPARTAMENTO DE LÍNGUAS ESTRANGEIRAS E TRADUÇÃO

PROGRAMA DE PÓS-GRADUAÇÃO EM LINGUÍSTICA APLICADA

Área de Concentração:

PRÁTICAS E TEORIAS NO ENSINO-APRENDIZAGEM DE LÍNGUAS

Linha de Pesquisa:

PROCESSOS FORMATIVOS DE PROFESSORES E APRENDIZES DE LÍNGUAS

O TRABALHO COM A ORALIDADE EM UM CURSO DE LICENCIATURA EM LÍNGUA ESPANHOLA (EAD): REALIDADES E NECESSIDADES

LUCIANA BRANDÃO DOURADO

Dissertação apresentada ao Programa de Pós-graduação em Linguística Aplicada do Departamento de Línguas Estrangeiras e Tradução - Instituto de Letras da Universidade de Brasília, como requisito parcial à obtenção do título de Mestre em Linguística Aplicada.

Orientador: Prof. Dr. Hélvio Frank de Oliveira

Brasília - DF

2016 


\title{
O TRABALHO COM A ORALIDADE EM UM CURSO DE LICENCIATURA EM LÍNGUA ESPANHOLA (EAD): REALIDADES E NECESSIDADES
}

Dissertação de Mestrado apresentada ao Programa de PósGraduação em Linguística Aplicada da Universidade de Brasília, como requisito parcial à obtenção do título de Mestre em Linguística Aplicada.

\section{Banca Avaliadora:}

\author{
Prof. Dr. Hélvio Frank de Oliveira - UEG/UnB \\ Presidente da Banca
}
Profa. Dra. Barbra do Rosário Sabota Silva - UEG
Examinador Externo
Prof. Dr. José Carlos Paes de Almeida Filho - UnB
Examinador Interno

\section{Prof. Dr. Yûki Mukai - UnB \\ Suplente}

Brasília - DF, 31 de março de 2016 
Aos meus pais,

fonte de amor e inspiração,

$$
\text { por tudo. }
$$




\section{Obrigada...}

Aos meus pais, Getúlio e Valdira, pelo amor incondicional, apoio e incentivo;

Aos meus irmãos, Elisabeth, Luiz Carlos e Susie, pela felicidade de saber que sempre posso contar com vocês;

Ao meu orientador, Hélvio Frank, pela orientação, pelos conhecimentos e pela paciência durante essa nossa caminhada;

Ao Instituto Federal de Educação, Ciência e Tecnologia de Brasília pelo incentivo, liberação de horas de pesquisa e de viagens para coleta de dados;

Aos professores Yûki Mukai e José Carlos Almeida Filho por todo conhecimento compartilhado e por serem minha referência na profissão;

À querida amiga Raquel Sena por estar presente nos melhores e nos piores momentos;

Aos amigos, de sempre e para todo o sempre, Eder de Souza, Marcella Fernandes, Patrícia Santana e Verônica Tanara pela amizade desde os tempos da graduação;

Aos queridos amigos Blenda Oliveira, Cândida Alves, Jefferson Sampaio e Jennifer Medeiros pelos momentos de diversão e pelas conversas que direcionam;

Aos amigos do trabalho e da vida, além de todos os que, de alguma forma, contribuíram para a conclusão dessa etapa. 
"Lecionar não é apenas ter conhecimento da língua e da didática de ensino, mas também estar a par das realidades de seus alunos e suprir suas necessidades".

(POLESEL FILHO 2001, p. 02. Grifo meu) 


\section{RESUMO}

Esta pesquisa, caracterizada como um estudo de caso quali-quantitativo, interpretativista, tem como objetivo analisar o trabalho com a oralidade em um curso de licenciatura em língua espanhola à distância. Levando em consideração que, na modalidade de licenciatura, os estudantes passam por um processo de aprender para ensinar a língua, o foco da análise são as atividades propostas por disciplinas do curso e também as percepções dos estudantes sobre o ensino de língua estrangeira, mais especificamente a prática da oralidade em um contexto de educação à distância. A pesquisa foi realizada no primeiro semestre do ano de 2015 em uma instituição pública de ensino da cidade de Natal, Rio Grande do Norte. Para a condução da pesquisa em duas turmas distintas - sendo uma turma de iniciantes e outra de concluintes -, foram utilizados os seguintes instrumentos de pesquisa: observação do ambiente de navegação virtual com registro de notas de campo das atividades realizadas, especialmente as endereçadas à oralidade, e também questionários e entrevistas semiestruturadas aplicados aos estudantes, visando a rastrear a percepção deles com relação ao trabalho com a oralidade. Ao total, quinze estudantes responderam à pesquisa. Os resultados demonstram que os estudantes estão se formando com grandes dificuldades em usar a língua de forma oral e questionam a pouca disponibilidade de recursos no ambiente virtual que lhes possam ser úteis no desenvolvimento da habilidade oral. Por fim, a pesquisa apresenta possibilidades, sugeridas pelos estudantes, para se avançar na formação de professores no que se refere à prática da oralidade em um contexto de aprendizagem à distância.

Palavras-chave: EaD. Oralidade. Língua Espanhola. Formação de professores de LE. 


\section{RESUMEN}

Este trabajo de investigación, que se caracteriza como un estudio de caso cualitativo y cuantitativo, interpretativo, busca analizar el trabajo con la oralidad en un curso de licenciatura en lengua española a distancia. Teniendo en cuenta que en ese tipo formación los estudiantes pasan por un proceso de aprendizaje para enseñar el idioma, el foco de análisis son las actividades propuestas durante el curso y también las percepciones de los estudiantes sobre la enseñanza de lenguas extranjeras, más concretamente, la práctica de la oralidad en un contexto de educación a distancia. La pesquisa se realizó en el primer semestre de 2015, en una institución pública de educación de la ciudad de Natal, Rio Grande do Norte. Para la realización del investigación en dos grupos distintos - un de principiantes y otro de concluyentes - se utilizaron los siguientes instrumentos de investigación: observación del ambiente de navegación virtual con notas de campo y registro de actividades, especialmente las dirigidas a la oralidad, así como entrevistas semiestructuradas y cuestionarios aplicados a los estudiantes con el fin de analizar su percepción con respecto a la práctica de la oralidad. Un total de quince alumnos respondió a la pesquisa. Los resultados muestran que los estudiantes se gradúan con gran dificultad para usar el lenguaje oral y cuestionan la limitada disponibilidad de recursos en el ambiente virtual que puedan trabajar la oralidad. Por último, la investigación presenta posibilidades sugeridas por los estudiantes para avanzar en la formación del profesorado en relación a la práctica de la oralidad en un contexto de aprendizaje a distancia.

Palabras-llave: EaD. Oralidad. Lengua española. Formación de profesores de LE 


\begin{abstract}
This research is characterized as a qualitative, quantitative and interpretative case study and it aims to discuss the work with orality in a Spanish Language Teacher Education in distance learning course. Taking into account that, in this type of degree, students go through a process of learning to teach the language, the focus of analysis are on activities proposed by subjects of the course and also students' perceptions about foreign language teaching, more specifically about the practice of orality in a context of distance education. The survey was conducted during the first semester of 2015 in a public education institution in the city of Natal, State of Rio Grande do Norte. To conduct research in two distinct classes - a class of beginners and another of preservice teachers - the following research instruments were used: observation of virtual navigation environment with field notes of activities, especially those related to orality, and also questionnaires and semi-structured interviews applied to students to know their perception with regard to work with orality. A total of fifteen students participated in the survey. The results show that students are graduating with great difficulties in using the language orally and they question the limited availability of resources in the virtual environment that would be useful in the development of oral skills. Finally, the research presents possibilities suggested by students to advance in teacher training with regard to the practice of orality in a context of distance learning.
\end{abstract}

Keywords: Distance education. Orality. Spanish language. Teachers training. 


\section{LISTA DE QUADROS}

Quadro 1: Busca bibliográfica na Biblioteca Digital Brasileira de Teses e Dissertações.........p. 19

Quadro 2: Evolução das matrículas em cursos, segundo a percepção dos respondentes..........p. 30

Quadro 3: Perfil ocupacional dos educandos dos cursos EaD............................................p. 31

Quadro 4: Vantagens e desvantagens da Web..................................................................p. 39 


\section{LISTA DE FIGURAS}

Figura 1: EaD no Brasil..................................................................................................p. 32

Figura 2: As quatro habilidades.................................................................................p. 47

Figura 3: Posição hierárquica....................................................................................... 51

Figura 4: Instruções para gravação de áudio....................................................................p. 69

Figura 5: Advertência sobre plágio …....................................................................... p. 73

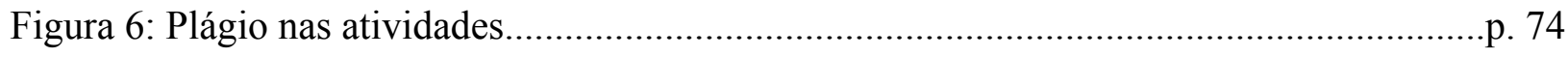

Figura 7: Texto sobre a cidade de Natal....................................................................... 82

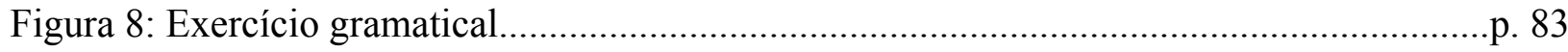

Figura 9: As habilidades na disciplina de Língua Espanhola II...........................................p. 84

Figura 10: Dificuldade de compreensão....................................................................p. 85

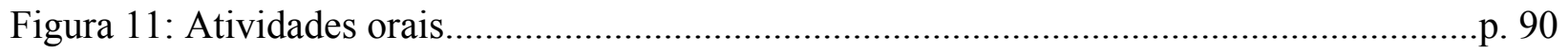




\section{LISTA DE GRÁFICOS}

Gráfico 1: Conhecimento prévio da língua espanhola em alunos do $2^{\circ}$ semestre...................p. 71

Gráfico 2: Conhecimento prévio da língua espanhola em alunos do $7^{\mathrm{o}}$ semestre...................p. 71

Gráfico 3: Conhecimento atual da língua espanhola em alunos do $2^{\circ}$ semestre.......................p. 76

Gráfico 4: Conhecimento atual da língua espanhola em alunos do $7^{\mathrm{o}}$ semestre......................p. 76

Gráfico 5: Habilidade mais importante segundo os alunos do $2^{\circ}$ semestre..............................p. 77

Gráfico 6: Habilidade mais importante segundo os alunos do $7^{\mathrm{o}}$ semestre.............................p. 78

Gráfico 7: Habilidade mais difícil de ser aprendida segundo os alunos do $2^{\circ}$ semestre...........p. 79

Gráfico 8: Habilidade mais difícil de ser aprendida segundo os alunos do $7^{\circ}$ semestre...........p. 79 


\section{LISTA DE ABREVIATURAS E SIGLAS}

\begin{tabular}{|l|l|}
\hline ABED & Associação Brasileira de Educação a Distância \\
\hline BDTD & Biblioteca Digital Brasileira de Teses e Dissertações \\
\hline EaD & Educação a distância \\
\hline EJA & Educação de Jovens e Adultos \\
\hline IBGE & Instituto Brasileiro de Geografia e Estatística \\
\hline LDB & Lei de Diretrizes e Bases da Educação \\
\hline LA & Linguística Aplicada \\
\hline LE & Língua Estrangeira \\
\hline LM & Língua Materna \\
\hline MEC & Ministério da Educação \\
\hline NTIC & Novas Tecnologias da Informação e Comunicação \\
\hline PNE & Plano Nacional da Educação \\
\hline PPC & Plano Pedagógico de Curso \\
\hline TIC & Tecnologias da Informação e Comunicação \\
\hline UnB & Universidade de Brasília \\
\hline
\end{tabular}




\section{SUMÁRIO}

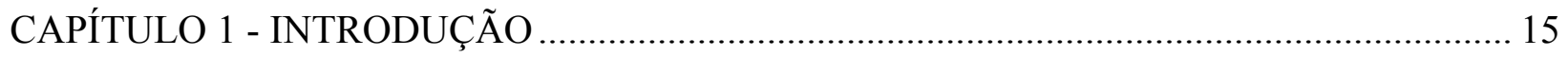

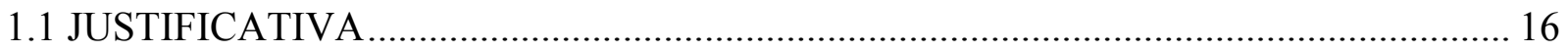

1.2 CONTEXTUALIZAÇÃO DA PESQUISA ……………............................................... 18

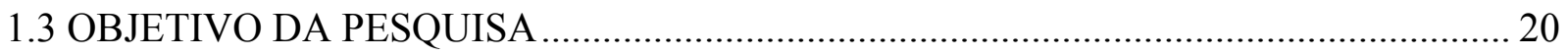

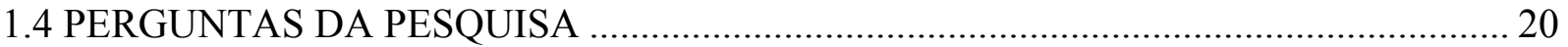

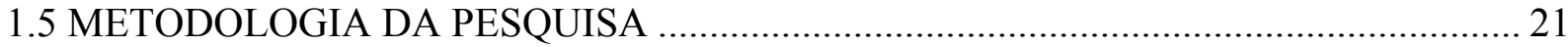

1.6 ORGANIZAÇÃO DESTA DISSERTAÇÃO ..................................................................... 21

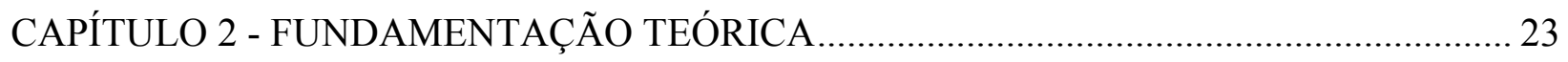

2.1 FALANDO DE EAD E ENSINO-APRENDIZAGEM DE LÍNGUAS ............................ 23

2.1.1 Conceito e desenvolvimento da $\mathrm{EaD}$................................................................ 23

2.1.2 EaD: fundamentação legal ................................................................................. 27

2.1.3 Números atuais da $\mathrm{EaD}$................................................................................. 30

2.1.4 EaD, tecnologias e o ensino de línguas....................................................................... 34

2.1.5 Motivação e aprendizagem de LE.............................................................................. 41

2.2 A ORALIDADE NO ENSINO DE LÍNGUAS ESTRANGEIRAS ................................... 44

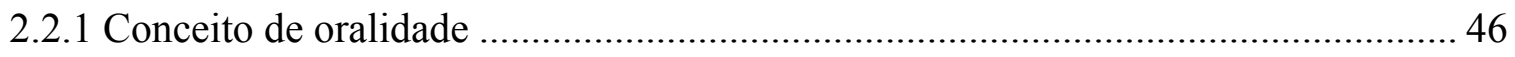

2.2.2 Características das atividades de expressão oral..................................................... 48

2.2.3 Oralidade nas abordagens e métodos do século XX ............................................... 50

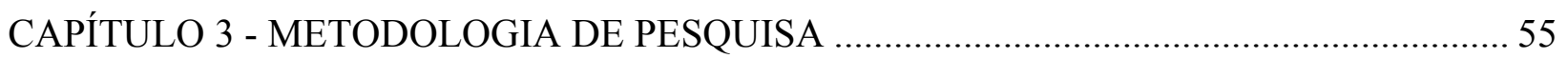

3.1 AS PESQUISAS QUALITATIVA, QUANTITATIVA E O ESTUDO DE CASO............55

3.2 A ESCOLHA DOS GRUPOS E OS MÉTODOS DE COLETA DE DADOS ..................... 58

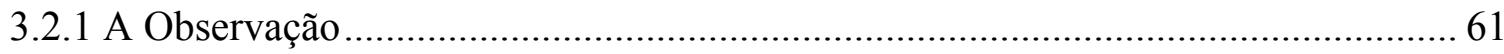

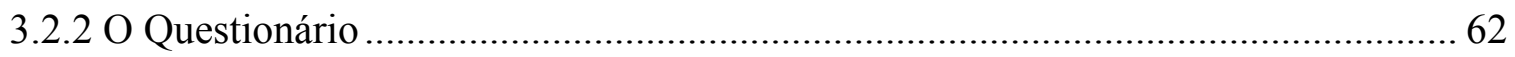

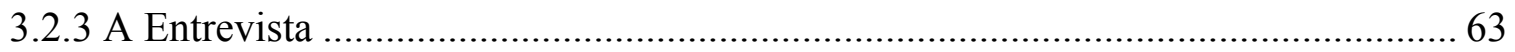




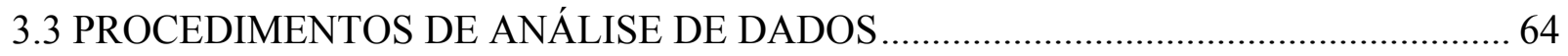

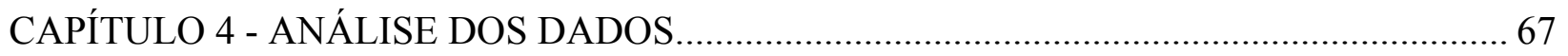

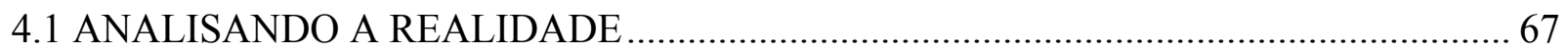

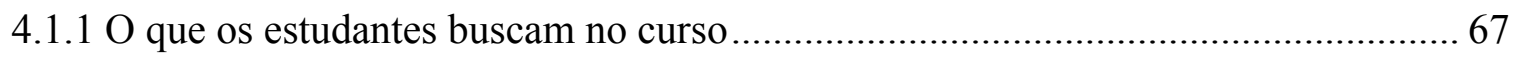

4.1.2 A questão do plágio no ambiente virtual ............................................................... 72

4.1.3 Habilidades linguísticas e formação de professores ................................................. 75

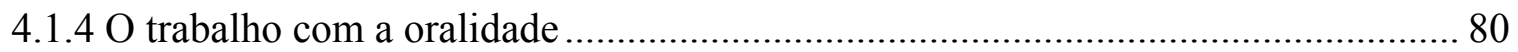

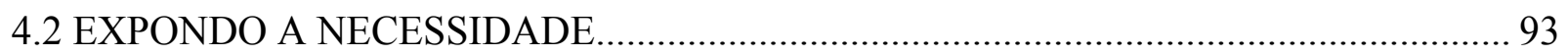

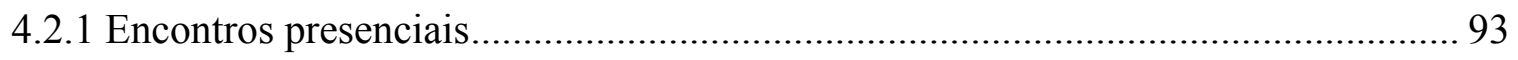

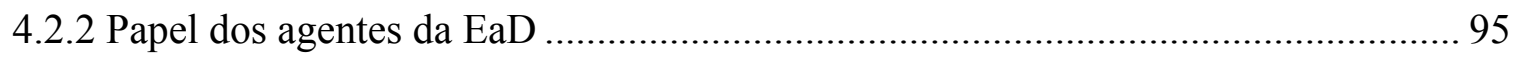

4.2.3 Recursos dentro do ambiente virtual................................................................. 98

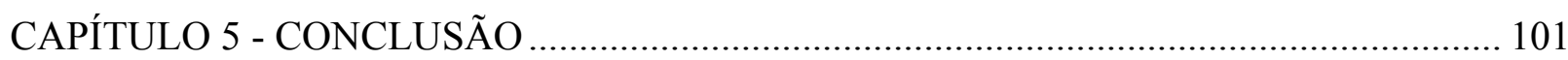

5.1 RETOMANDO AS PERGUNTAS DE PESQUISA ......................................................... 101

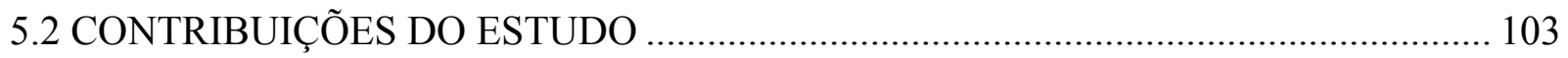

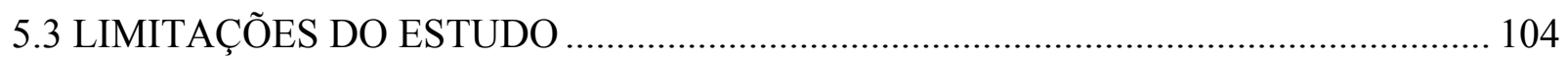

5.4 SUGESTÕES PARA FUTURA PESQUISAS …………………………………........ 104

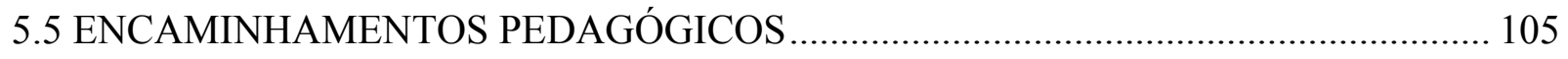

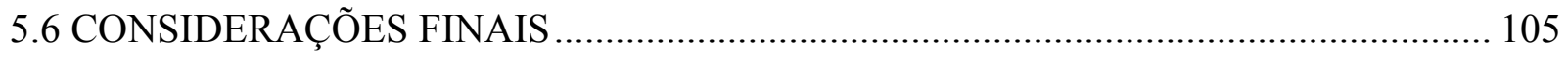

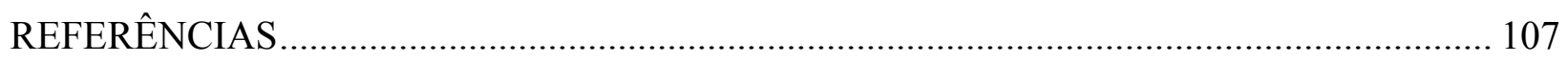

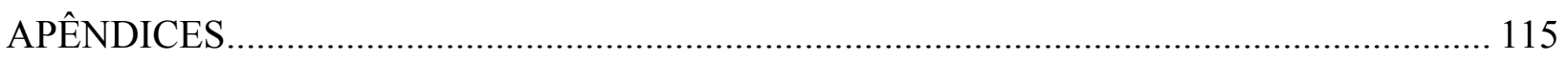

APÊNDICE I - Termo de solicitação de acesso para pesquisa ................................................. 115

APÊNDICE II - Perguntas dos questionários ..................................................................... 117

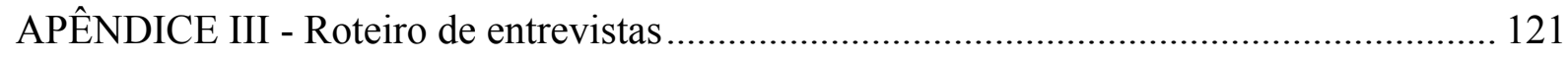

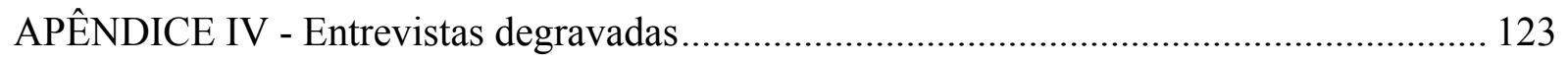




\section{CAPÍTULO 1}

\section{INTRODUÇÃO}

Dibujando mi camino, organizando mi destino... ${ }^{1}$

A partir dos dados do Censo da Educação Superior de 2012, é possível observar que a educação a distância (EaD) no Brasil cresceu mais que a educação presencial, comparando-se os anos de 2011 e 2012. De acordo com o Censo, em um ano, houve um aumento de 12,2\% nas matrículas da $\mathrm{EaD}$, enquanto na educação presencial o aumento é de 3,1\%. Quando observei os números da $\mathrm{EaD}$ na formação superior, eles mostram que as matrículas de bacharelado representam $67,1 \%$ do total, enquanto os cursos de licenciatura representam $19,5 \%$. O censo aponta, ainda, que o ensino superior atingiu, no ano de 2012, 7.037 .688 de matrículas na graduação, o que representa crescimento de 4,4\% em relação a 2011. O número de concluintes teve uma variação menor, 3,3\%, passando de $1.016 .713 \mathrm{em} 2011$ para $1.050 .413 \mathrm{em} 2012$.

Somo aqui os dados do Censo da Educação Superior de 2013, os quais revelam que em 2003 havia apenas 52 cursos na modalidade $\mathrm{EaD}$, enquanto que atualmente são mais de 1,2 mil cursos a distância no Brasil, que equivalem a uma participação superior a 15\% nas matrículas de graduação. Hoje as universidades são responsáveis por $90 \%$ da oferta de cursos, e representam $71 \%$ das matrículas nessa modalidade. O referido documento revela também que há equilíbrio na oferta dos cursos a distância entre os diferentes graus acadêmicos, mas em termos de oferta há predomínio da participação das universidades privadas, o que se justifica pelo tamanho dessa rede de ensino e pela forma de acesso aos cursos.

É a partir desses dados iniciais que introduzo esta pesquisa, pois eles despertaram o meu interesse em trabalhar com $\mathrm{EaD}$, visto que, com base nos dados do censo, é possível verificar a expansão da $\mathrm{EaD}$ em nível superior no Brasil. Com a expansão vem a necessidade de se refletir acerca da qualidade. De acordo com Bossu (2010), a falta de clareza na definição de qualidade ${ }^{2} \mathrm{e}$ a falta de literatura disponível sobre as medidas e estruturas adotadas para avaliar qualidade em

\footnotetext{
${ }^{1}$ Desenhando meu caminho, organizando meu destino.

2 "Na educação, mais precisamente para medir os atributos de um curso, de uma disciplina ou até mesmo de uma universidade inteira com suas numerosas atividades e serviços, qualidade é usada para definir o grau de excelência e distinção de uma determinada universidade”. (BOWDEN \& MARTON 2003 apud BOSSU 2010, p. 03).
} 
EaD ainda são perceptíveis no contexto atual. Nesse sentido, as pesquisas nessa área levantam dados que são importantes para reflexão do tema.

\subsection{JUSTIFICATIVA}

Observando essa expansão, o que se espera é que um curso na modalidade a distância seja uma opção de escolha que não apresente impactos negativos no processo de ensinoaprendizagem do estudante, e que esse sujeito tenha uma formação completa, e que a modalidade de ensino seja apenas um detalhe na escolha. Esse desejo se potencializa quando adentramos o campo do nível superior, mais especificamente a licenciatura, tendo em vista que estamos tratando da formação de novos professores, que, ao atuarem com seus estudantes, estarão multiplicando o conhecimento adquirido.

Nesse contexto surgiu a minha preocupação sobre a formação de professores no contexto da EaD, mais especificamente na formação de professores de Língua Estrangeira (LE). O foco da preocupação nesse contexto é se o curso na modalidade $\mathrm{EaD}$ oferece o suporte necessário para a aprendizagem e prática da LE estudada. Concordando com Chagas (1957 apud LEFFA 1988), no caso de professores de LE, é necessário um ensino que envolva as quatro habilidades linguísticas, já que o entendimento aqui é que há uma interdependência íntima dos quatro aspectos instrumentais do ensino dos idiomas - ouvir, falar, ler e escrever - e que nenhum deles poderá ser atingido isoladamente, sem que se trabalhem os demais.

Apesar de haver uma ligação direta entre aprender uma LE e dominar as quatro habilidades linguísticas citadas, o foco deste trabalho é a habilidade oral, por entender que a prática da oralidade, em geral, se dá por um processo síncrono, com participação de um emissor e ao menos um receptor, e que, para acontecer no contexto da EaD, precisa de propostas definidas e organizadas.

Durante a minha graduação (licenciatura em língua espanhola), realizada presencialmente na Universidade de Brasília (UnB), pude acompanhar o crescimento dos meus colegas, e o meu próprio, ao vencer os desafios, principalmente relacionados à aprendizagem ${ }^{3}$ da LE em questão. Antes mesmo de pensar em como dar aula, o nosso receio estava relacionado ao "dominar" a LE da qual seríamos professores; ou seja, minha preocupação era sair da universidade com

\footnotetext{
${ }^{3}$ Utilizo o termo "aprendizagem" apoiada em Krashen (1981), que faz a distinção entre aprendizagem (estudo formal) e aquisição (contato direto).
} 
condições de ministrar uma aula de espanhol na língua-alvo, pois, assim como muitos outros colegas, entrei com uma noção muito rasa da língua, tendo em vista que provas de proficiência ${ }^{4}$ não são realizadas para se ingressar num curso de licenciatura em LE.

Grande parte dos alunos de minha turma, e eu também me insiro nesse grupo, não possuía uma comunicação plena em língua espanhola, não conseguia se expressar em termos de escrita, e, principalmente, oralmente; mas, com o constante contato com os colegas e com os professores que ministravam aula em língua espanhola, o conhecimento e a sensação de "dominar" a língua foram se aproximando. Havia uma sensação de imersão na língua e na cultura, por mais que só ocorresse nos momentos em que estivéssemos na universidade. Por fim, ao término do curso, já no estágio supervisionado, o receio de não saber falar a língua da qual eu seria professora já havia passado.

Importante destacar que há uma relação de poder quando se trata da capacidade de se comunicar oralmente. De acordo com Gillis (2013), a proficiência em cada uma das quatro habilidades é necessária para um completo desenvolver da língua, permitindo comunicação; no entanto, a capacidade de se comunicar oralmente fornece vantagens ao falante, como a interação, com feedback imediato do interlocutor, a possibilidade de persuadir e dirigir, utilizando diferentes recursos da $\operatorname{voz}^{5}$ (frequência, intensidade, ressonância, articulação e respiração), habilidades estas usadas por professores, gerentes, líderes militares, políticos, etc.; dessa forma, a relação entre poder e uma eficiente comunicação oral se estabelece.

Nesse sentido, Couto \& Maciel (2012) destacam que a oralidade e a sua prática devem estar presentes no dia-a-dia do professor de LE, pois um professor que não fala em espanhol dificilmente poderá exigir que seus alunos falem o idioma. Por isso, o futuro professor de LE tem a necessidade de saber expressar-se oralmente na língua para a qual está sendo formado como professor. Com base nessas informações, repensando a minha experiência durante a graduação e

\footnotetext{
${ }^{4}$ Apesar de, durante o texto, mencionar a falta de provas de proficiência em língua para a entrada em cursos de licenciatura em LE, não acredito que a prova seja uma ferramenta que resolva o problema da formação de professores de LE na universidade, pois ela pode levar à uma elitização dos cursos.

${ }^{5}$ De acordo com Canhetti (2008 citando GAYOTTO 1997), esses são recursos primários da voz. A autora os define da seguinte forma: a frequência está relacionada com a altura, que é expressa em Hertz (Hz); a intensidade é o grau da força expiratória com que o som é produzido, força que se manifesta acusticamente na menor ou maior amplitude de vibração das pregas vocais; a ressonância é um sistema em que, após a emissão do som nas pregas vocais, haverá amplificação e amortecimento de determinados harmônicos; a articulação refere-se aos ajustes motores realizados pelos órgãos fonoarticulatórios; já a respiração, apresenta dois diferentes ciclos: inspiração e expiração e pode ser realizada nos modos - nasal, bucal e mista.
} 
observando a expansão da $\mathrm{EaD}$, decidi pesquisar como se dá a prática da LE em um curso EaD, em especial a prática da oralidade, visando a construir um trabalho que contribua para uma reflexão sobre a relevância de se observar o aspecto da oralidade em cursos de formação de professores de LE na modalidade EaD.

\subsection{CONTEXTUALIZAÇÃO DA PESQUISA}

A pesquisa foi realizada no primeiro semestre do ano de 2015 na região nordeste, mais especificamente no estado do Rio Grande do Norte. A instituição escolhida trabalha com ensino superior, médio, técnico-profissional e outras modalidades de ensino, e, por ser pública e federal, está vinculada diretamente ao Ministério da Educação (MEC).

Atualmente, a instituição possui cerca de 28 mil alunos em seus 21 campi distribuídos por todas as regiões do Estado, atuando de forma verticalizada, oferecendo cursos nas modalidades presencial e à distância. Para esta pesquisa, foi escolhido o campus da cidade de Natal, capital do estado.

A escolha da instituição foi realizada considerando os seguintes aspectos: além de oferecer o curso de licenciatura em língua espanhola na modalidade a distância, o curso oferecido pela instituição é relativamente novo, tendo formado apenas uma turma, no segundo semestre de 2014. Além disso, essa escolha foi motivada pelo fato de eu trabalhar em uma instituição da mesma rede da instituição pesquisada. Dessa forma, a pesquisa contribui para a minha formação acadêmica enquanto mestranda, mas também contribui para o meu cenário profissional, tendo em vista que esse tipo de pesquisa visa a melhorar a qualidade de ensino a partir das reflexões suscitadas e valorizar a rede, incentivando a pesquisa dentro da instituição, com fins à excelência no ensino.

Buscar informações sobre a formação de professores se faz necessário, tendo em vista que, de acordo com os dados do Programa Nacional de Educação (PNE) ${ }^{6}$, dos 2.101.408 docentes que atuam na Educação Básica do país, 22\% não possuem formação de nível superior, ou estão formados em outras áreas, diferente das que atuam em sala de aula. Estes são dados do Censo Escolar de 2012. Aqui não se contemplam questões relacionadas à qualidade da formação, mas esses dados são norteadores, tendo em vista que a EaD começa a atuar como ferramenta

\footnotetext{
${ }^{6}$ Dados disponíveis no site http://www.observatoriodopne.org.br
} 
para a formação desses profissionais sem nível superior que o PNE aponta em seus dados, além de buscar atender à demanda de expansão da educação básica, que precisa de professores.

Outra informação que merece ser citada é que, nos dados por região, o Censo Escolar apontou grande disparidade no Norte e no Nordeste; nestes locais há menos docentes com formação de nível superior que nas outras regiões do Brasil. O contexto de formação no nordeste é uma motivação a mais para a presente pesquisa, podendo este estudo trazer reflexões sobre formação inicial de professores na região citada.

Sobre as pesquisas anteriores sobre a oralidade no contexto de ensino de LE na modalidade EaD, busquei pelos termos que balizam a presente pesquisa na Biblioteca Digital Brasileira de Teses e Dissertações (BDTD) e os resultados seguem a seguir:

\section{Quadro 1 - Busca bibliográfica na Biblioteca Digital Brasileira de Teses e Dissertações}

\begin{tabular}{|cc|}
\hline Termos de busca & Resultados encontrados \\
\hline Oralidade Espanhol EaD & 0 \\
\hline Oralidade EaD & 1 \\
\hline Expressão oral EaD & 2 \\
\hline
\end{tabular}

\begin{tabular}{|c|c|c|}
\hline Título & Ano & Palavras-chave \\
\hline $\begin{array}{l}\text { Marcas da oralidade na escrita: a } \\
\text { repetição em fórum de discussão em } \\
\text { EAD. [Dissertação] }\end{array}$ & 2013 & $\begin{array}{l}\text { Oralidade. Escrita. Repetição. } \\
\text { Educação a Distância. }\end{array}$ \\
\hline $\begin{array}{l}\text { O ensino e a aprendizagem da produção } \\
\text { oral em língua estrangeira na educação } \\
\text { a distância. [Dissertação] }\end{array}$ & 2012 & $\begin{array}{l}\text { Linguística. Língua inglesa. } \\
\text { Estudo e ensino. Ensino a } \\
\text { distancia. }\end{array}$ \\
\hline Compreensão leitora. [Dissertação] & 2011 & $\begin{array}{l}\text { Linguística. Língua } \\
\text { portuguesa. Estudo e ensino. } \\
\text { Ensino a distância. } \\
\text { Compreensão na leitura. } \\
\text { Cursos de graduação }\end{array}$ \\
\hline
\end{tabular}


O levantamento levou em consideração pesquisas realizadas de 2010 a 2015 e a escolha da base do BDTD se deve por possuir uma grande base de dados, reunindo, em um só portal de busca, as teses e dissertações defendidas em todo o país e por brasileiros no exterior.

A partir dos dados anteriores é possível verificar que há poucas pesquisas sobre a oralidade no contexto de LE na modalidade EaD. A pesquisa que mais se aproxima da presente pesquisa é a intitulada "O ensino e a aprendizagem da produção oral em língua estrangeira na educação a distância”, de 2012, no entanto, a pesquisa trabalha com o ensino de língua inglesa. Além disso, o curso analisado em 2012 possui uma estrutura diferente do curso em análise neste trabalho, pois contava com aulas presenciais, sendo considerado um curso semipresencial.

\subsection{OBJETIVO DA PESQUISA}

Com base no contexto exposto, a presente pesquisa teve como finalidade investigar o trabalho com a oralidade, com base nas observações da plataforma e dados coletados com os participantes, e refletir sobre o que seria necessário, com base na percepção dos estudantes, no campo de aprendizagem ${ }^{7}$ e prática de LE, especificamente o espanhol, em um contexto de formação de professores por meio de um curso de graduação a distância.

Mais especificamente, objetiva:

- Refletir sobre as atividades propostas no ambiente virtual endereçadas à oralidade, discutindo, a partir da voz dos cursistas e em diálogo com as teorias, o que seria necessário nesse tipo de contexto de ensino para se avançar na formação de professores de LE.

\subsection{PERGUNTAS DA PESQUISA}

A partir do objetivo da pesquisa, este estudo procura responder à seguinte pergunta de pesquisa: a modalidade a distância, na forma como está praticada na situação de pesquisa, atende de que forma à prática da oralidade no ensino de LE (espanhol)?

Mais especificamente, este trabalho pretende responder às seguintes perguntas:

\footnotetext{
${ }^{7} \mathrm{O}$ termo aprendizagem foi utilizado nesse contexto por ser grande o número de estudantes que ingressam no curso de licenciatura em LE sem conhecimento da língua para qual serão professores, sendo comum o processo de aprendizagem dessa língua durante o curso. Portanto, na graduação o estudante aprende para ensinar.
} 
- Quais características predominam no curso EaD (espanhol) no que se refere ao trabalho com a oralidade do idioma?

- Como o trabalho com a oralidade é visto pelos alunos do curso?

- Quais práticas podem ser inseridas nesse tipo de curso visando melhorias no contexto da oralidade no ensino de LE por meio da EaD?

\subsection{METOdOLOGIA DA PESQUISA}

Como metodologia para esta pesquisa, utilizo o estudo de caso de caráter qualitativointerpretativista (FALTIS 1997; STAKE 1994), mas que contempla características da pesquisa quantitativa (GÜNTHER 2006) como gráficos e outros dados numéricos.

Com o intuito de coletar dados para responder às perguntas de pesquisa, foram utilizados instrumentos como a observação (ADLER \& ADLER 1994) feita por meio da navegação virtual com registro das atividades realizadas; aplicação de questionário (GIL 1999) e entrevistas semiestruturadas (ROSA \& ARNOLDI 2006) realizadas presencialmente no polo de apoio aos estudantes. Quinze estudantes do segundo e do sétimo semestre responderam à pesquisa por meio de questionários e entrevistas; já a observação ocorreu em três disciplinas do curso.

O referencial teórico, que servirá de aporte para a análise dos dados, está direcionado a questões como EaD (MORAN 2002; HERMIDA \& BOMFIM 2006;), tecnologias e ensino de línguas (PAIVA 2001, 2015; LEFFA 2009; ALMEIDA FILHO 2005; 2008), além do trabalho com a oralidade no contexto de aprendizagem de línguas estrangeiras (PINILLA GÓMEZ 2005; MARÍN 2005).

A partir dos dados obtidos, foram feitas análises, observando pontos relevantes e categorizando-os (ANDRÉ 2013). A criação das categorias se deu com base nos achados durante a coleta de dados e na relevância dessas categorias para a discussão do objetivo deste trabalho. Dessa forma, como resultado, o estudo trará reflexões concernentes à formação docente de LE no contexto da EaD.

\subsection{ORGANIZAÇÃO DESTA DISSERTAÇÃO}

O presente trabalho está divido em cinco partes: introdução; capítulo teórico; capítulo metodológico; capítulo de análise de dados e conclusão. 
No capítulo teórico são tratados os temas EaD e Ensino de Línguas (conceituação; legislação; crescimento da EaD no Brasil; novas tecnologias no ensino de línguas; motivação no ensino de línguas) e Oralidade (conceituação; características; oralidade nas abordagens e métodos do século XX). O capítulo metodológico apresenta a base metodológica utilizada na pesquisa: método; natureza; contexto; participantes e instrumentos para coleta de dados. No capítulo de análise de dados, tendo em vista os objetivos específicos propostos, apresento categorias e discuto os dados obtidos. Por último, na conclusão, retomo as perguntas de pesquisa, levanto as possíveis contribuições deste estudo, aponto as limitações da pesquisa, apresento sugestões para futuras pesquisas, encaminhamentos pedagógicos e, por fim, exponho as considerações finais. 


\section{CAPÍTULO 2}

\section{FUNDAMENTAÇÃO TEÓRICA}

"Relevante mencionar que no imaginário social as quatro habilidades no processo de ensino-aprendizagem de línguas (ler, escrever, falar e ouvir) tenham se fundido em uma única habilidade [a oralidade]."

(FERREIRA 2012, p. 43)

Neste capítulo trato de teorias que servirão de aporte no momento da análise de dados e divulgação dos resultados. Os temas aqui abordados são relativos à $\mathrm{EaD}$, novas tecnologias no ensino de línguas, motivação, ensino-aprendizagem de LE e oralidade.

\subsection{FALANDO DE EAD E ENSINO-APRENDIZAGEM DE LÍNGUAS}

Tendo em vista que a pesquisa se dará em um contexto de curso $\mathrm{EaD}$, faz-se necessário adentrar esse campo, conceituando e buscando compreender o processo de desenvolvimento e expansão dessa modalidade de ensino, além de relembrar o momento em que o ensino de línguas passou a ser realizado em um contexto a distância, com o uso de tecnologias como o computador.

\subsubsection{Conceito e desenvolvimento da EaD}

Moran (2002) conceitua a EaD como o processo de ensino-aprendizagem, mediado por tecnologias, em que professores e alunos estão separados espacial e/ou temporalmente; ou seja, professores e alunos não estão normalmente juntos, fisicamente, mas podem estar conectados, interligados por tecnologias, como a Internet; mas também podem ser utilizados o correio, o rádio, a televisão, o vídeo, o CD-ROM, o telefone, o fax e tecnologias semelhantes.

A EaD não é um fenômeno recente na história mundial; de acordo com Nunes (2009), a primeira notícia que se registrou desse novo modo de ensinar foi o anúncio das aulas por correspondência ministradas por Caleb Philips, em março de 1728, nos Estados Unidos. No Brasil, de acordo com Alves (2009), as pesquisas mostram que, um pouco antes de 1900, já existiam anúncios em jornais de circulação no Rio de Janeiro oferecendo cursos profissionalizantes por correspondência. 
Alves (2009) afirma ainda que a EaD no Brasil é marcada por uma trajetória de sucesso, tendo apenas a existência de alguns momentos de estagnação por falta de políticas públicas para o setor. Litto (2009) complementa esse contexto, afirmando que o Brasil vive três tendências econômicas nas quais a $\mathrm{EaD}$ está presente em alguma medida. A primeira tendência é a agrícola, pois muitas pessoas que moram nas áreas rurais, distantes dos centros urbanos, recorrem à modalidade a distância para dar prosseguimento aos estudos, por meio dos materiais impressos dos cursos por correspondência. A segunda tendência é a industrial, baseada nos cursos via rádio e televisão; e, por fim, a tendência da tecnologia da informação, que, de acordo com o referido autor, "cresce rapidamente devido à aceleração das inovações que se estendem também à área de comunicação" (LITTO 2009, p. 18).

Com base nas tendências da EaD, é possível traçar um perfil dos seus estudantes. As justificativas mais comuns para a matrícula em cursos a distância estão relacionadas à busca por melhorias rápidas na carreira, à falta de tempo e à distância para se chegar a locais de ensino presencial. Nunes (2009) afirma que a $\mathrm{EaD}$ está voltada especialmente, mas não exclusivamente, para adultos, que, em geral, já estão no mundo corporativo e dispõem de tempo suficiente para estudar, a fim de completar sua formação básica ou buscar algo complementar. O mesmo autor destaca que o público tende a não ser convencional, ou seja, além dos adultos que trabalham, há pessoas que, por vários motivos, não podem sair de casa: pessoas com deficiência; populações de áreas de povoamento disperso; ou simplesmente pessoas que se encontram distantes de instituições de ensino.

Apesar de a EaD não ser um fenômeno recente, ela é vista como novidade em virtude do uso das novas tecnologias da informação e comunicação, as denominadas NTIC ${ }^{8}$. Estas apareceram em um contexto em que autores afirmavam que a $\mathrm{EaD}$ havia se configurado, em grande parte, como repositório de materiais da educação presencial.

Estamos numa fase de transição na educação a distância. Muitas organizações estão se limitando a transpor para o virtual adaptações do ensino presencial (aula multiplicada ou disponibilizada). Há um predomínio de interação virtual fria (formulários, rotinas, provas, e-mail) e alguma interação on-line. (MORAN 2000, p. 59)

\footnotetext{
${ }^{8}$ As NTIC são compostas por um conjunto de tecnologias que possuem uma diversidade de recursos, como é o caso do computador conectado à internet, ferramentas essas que proporcionam interatividade e outras possibilidades de interação entre os atores da $\mathrm{EaD}$. No contexto da $\mathrm{EaD}$, o termo NTIC está ligado à fase em que a EaD passa a explorar a internet.
} 
Para mudar esse cenário, a EaD vem passando por constantes mudanças; a cada momento, novas ferramentas de interação estão sendo inseridas em seu contexto. Há a necessidade de interação e a interlocução entre todos os que estão envolvidos nesse processo, buscando deixar de ser uma interação fria, em que não há a construção do conhecimento, pois a informação chega pronta, assim como afirma Moran (2000). Ele ainda destaca que a EaD não é um fast-food, em que o aluno se serve de algo pronto, mas, sim, uma prática que permite um equilíbrio entre as necessidades e as habilidades.

A EaD, portanto, vem experimentando, nos últimos anos, as mudanças no cenário educacional, entre as quais, muitas delas, acontecem em decorrência da introdução, primeiramente das Tecnologias da Informação e Comunicação (TIC) e na sequência das NTIC. De acordo com Belloni (2009), verifica-se a capacidade da EaD em articular as tecnologias à sua prática pedagógica, agindo de maneira essencial para o processo educativo. Desse modo, as transformações tecnológicas que afetam a vida social como um todo chegam ao contexto da educação e ajudam a intensificar a cultura da EaD mediada principalmente pelos cursos via $W e b$.

Assim, as NTIC proporcionam novos meios para a realização da $\mathrm{EaD}$, o que coloca a modalidade de ensino em um novo tempo: o tempo dos cursos online, em que a interatividade e interação acontecem na maior parte do processo de ensino e aprendizagem por meio de computadores e outros dispositivos conectados à Internet, surgindo então uma nova forma de construção do conhecimento.

Hermida \& Bonfim (2006) afirmam que a EaD, quando se trata de cursos de ensino superior, aparece em um momento que reúne a tendência desse tipo de educação (superior), constatada a partir da década de 1990, associada aos novos desafios resultantes do desenvolvimento das NTIC. De acordo com Segrega (2005 apud HERMIDA \& BONFIM 2006), a globalização modificou o sistema educacional de países desenvolvidos e em desenvolvimento de formas diferentes, mas, ainda assim, é possível identificar tendências em comum, algumas delas são: 1) mudanças na organização e no tipo de trabalho, pois agora exigem um nível mais elevado de educação da força de trabalho e a requalificação permanente; 2) pressão crescente sobre os governos dos países em desenvolvimento para que estes invistam mais em educação, para poder preparar uma força de trabalho mais competitiva, produzir técnicas sofisticadas, que permitam competir num mercado mundial cada vez mais globalizado; 3) a complexidade 
crescente da educação superior, que tornou seus currículos mais diversificados e passou a requerer estudantes adeptos do domínio de novas tecnologias e vários idiomas; 4) o desenvolvimento da educação virtual, nem sempre com o objetivo de expandir a educação pelo menor custo, com a tendência da educação virtual vir a tornar-se a forma predominante de educação - em especial na educação superior. (p. 166)

Ainda com base em Hermida \& Bonfim (2006), a EaD, direcionada para o ensino superior, surge em uma fase em que a educação presencial já não dá conta de atender às demandas educacionais, por isso a oferta de educação na modalidade à distância pode contribuir para atender a essas demandas urgentes, que estão relacionadas à formação ou capacitação de docentes para a educação básica, entre outros profissionais, bem como à formação continuada, em especial no interior do país, onde as dificuldades de acesso ao ensino aumentam cada dia mais.

Essa informação é confirmada por Kipnis (2008), quando afirma que experiências mais recentes utilizam cursos de graduação na modalidade EaD para formar professores em exercício; isso em parceria com secretarias de educação e dos estados e municípios. Surgiram projetos como o Veredas, que em parceria de 18 universidades, centros universitários e outras instituições de ensino superior, com a Secretaria de Educação de Minas Gerais, ofertou 15 mil vagas destinadas a professores em exercício. Depois desse projeto, muitos outros, em diversas regiões do Brasil, continuaram acontecendo no intuito de formar professores em exercício no contexto de $\mathrm{EaD}$.

A EaD hoje faz parte do contexto de educação no Brasil e apresenta uma série de vantagens, como interatividade, flexibilidade de horário e autonomia (o estudante pode definir seu próprio ritmo de estudo). No entanto, vale destacar que a EaD demanda uma responsabilidade maior do aluno, pois este deve redobrar seus esforços para alcançar um nível significativo de aprendizagem (HERMIDA \& BONFIM 2006).

Nesse sentido, importante destacar que a questão da gestão do tempo por parte dos estudantes é preocupante. De acordo com Leffa (2009), a limitação de tempo é um problema sério tanto para o ensino a distância como para o presencial. De acordo com a sua pesquisa em alguns grupos de graduação pela modalidade $\mathrm{EaD}$, o autor afirma que na $\mathrm{EaD}$ o problema é ainda mais sério, porque, além da falta de tempo, surge também a necessidade de seu gerenciamento, 
mas a principal razão que leva a maioria dos alunos a optar pela modalidade EaD é a falta de tempo para ir à sala de aula presencial, com local e hora marcados.

Dessa forma, o estudante necessita gerenciar o seu tempo para os estudos em EaD de uma forma eficiente. $\mathrm{O}$ fato é que, na sala de aula presencial, o tempo é estabelecido pela instituição, enquanto que na EaD o tempo e sua gestão estão nas mãos de cada estudante. O estudante que possuir uma boa gestão do seu tempo é que irá desfrutar com consciência dos benefícios da EaD. De acordo com Pausch (2008 apud LEFFA 2009, p. 159), “os computadores são mais rápidos, mas tomam mais tempo. [...] A tecnologia pode acelerar um vídeo ou rodá-lo em câmara lenta, mas não pode compactar ou expandir o tempo".

$\mathrm{O}$ avanço das NTIC no contexto da EaD ocorreu principalmente pelo fato de o país ter ampliado o número de linhas telefônicas nesse período, o que ocasionou a utilização da Internet por um número maior de pessoas, embora saibamos que o acesso a um computador conectado à rede ainda hoje não faz parte da realidade da maioria das pessoas no Brasil; no entanto, o que vemos é a crescente expansão da $\mathrm{EaD}$, de acordo com o resultado do último censo, que se detalha após o tópico sobre legislação da EaD.

\subsubsection{EaD: fundamentação legal}

No percurso histórico da EaD no Brasil, a Lei de Diretrizes e Bases da Educação (LDB) no 9394/1996 dedica um artigo específico para disciplinar a referida modalidade de ensino:

Art 80. O poder público incentivará o desenvolvimento e a veiculação de programas de ensino a distância, em todos os níveis e modalidades de ensino, e de educação continuada.

$\S 1^{\circ}$ A educação a distância, organizada com abertura e regime especiais, será oferecida por instituições especificamente credenciadas pela União.

$\S 2^{\circ}$ A União regulamentará os requisitos para a realização de exames e registro de diploma relativos a cursos de educação a distância.

$\S 3^{\circ}$ As normas para produção, controle e avaliação de programas de educação a distância e a autorização para sua implementação, caberão aos respectivos sistemas de ensino, podendo haver cooperação e integração entre os diferentes sistemas.

$\S 4^{\circ}$ A educação a distância gozará de tratamento diferenciado, que incluirá:

I - custos de transmissão reduzidos em canais comerciais de radiodifusão sonora e de sons e imagens;

II - concessão de canais com finalidades exclusivamente educativas;

III - reserva de tempo mínimo, sem ônus para o poder público, pelos concessionários de canais comerciais. 
De acordo com o dispositivo legal, a EaD será incentivada pelo Poder Público, mas a sua oferta não será restrita a ele. Significa dizer que as instituições privadas também poderão ofertar cursos a distância, devendo seguir parâmetros mínimos dispostos na lei. A partir dessa legislação, a EaD passa a ter maior visibilidade e inicia-se o processo de crescimento da modalidade de ensino.

Cabe destacar que o parágrafo quarto reserva o tratamento diferenciado da $\mathrm{EaD}$, considerando a perspectiva de uma oferta mediada pela TV (concessão de canais, custos de transmissão e reserva de tempo mínimo pelos concessionários de canais comerciais). Observa-se que o período histórico de elaboração da LDB, associado ao histórico da própria EaD no Brasil e no mundo, sinalizava para o uso das tecnologias telemáticas assíncronas ${ }^{9}$, sobretudo com a utilização da televisão.

Atualmente, o uso da televisão deu espaço à Internet, trazendo uma nova concepção de $\mathrm{EaD}$ e de relação tempo/espaço no processo de ensino-aprendizagem. Contudo, as novas tecnologias que surgiam na sociedade, quando aplicadas no âmbito educacional, não descartaram as anteriores. Elas possuem um caráter convergente, ou seja, as tecnologias se complementam e se convergem para uma finalidade maior: colaborar na construção do conhecimento. (DIAS \& LEITE 2010)

A partir do artigo 80 da LDB, foi criado o Decreto $n^{\circ} 5622$ de 19 de dezembro de 2005 que regulamenta a EaD. A regulamentação por meio desse decreto trouxe a expansão da $\mathrm{EaD}$, principalmente na esfera privada. O Decreto $n^{\circ} 5622$, além de regulamentar o conteúdo disposto no artigo 80 da LDB, caracteriza a EaD como uma modalidade:

\begin{abstract}
Art. $1^{\circ}$ - Para os fins deste Decreto, caracteriza-se a educação a distância como modalidade educacional na qual a mediação didático-pedagógica nos processos de ensino e aprendizagem ocorre com a utilização de meios e tecnologias de informação e comunicação, com estudantes e professores desenvolvendo atividades educativas em lugares ou tempos diversos.
\end{abstract}

Além da definição de EaD, o Decreto enfatiza a especificidade da metodologia e da gestão, as áreas de abrangência e a previsão de encontros presenciais nas seguintes situações:

\footnotetext{
${ }^{9}$ Tecnologias telemáticas assíncronas são tecnologias com vídeo, mas que a interação não se dá em tempo real.
} 
Art. 13. Para os fins de que trata este Decreto, os projetos pedagógicos de cursos e programas na modalidade a distância deverão:

I - obedecer às diretrizes curriculares nacionais, estabelecidas pelo Ministério da Educação para os respectivos níveis e modalidades educacionais;

II - prever atendimento apropriado a estudantes portadores de necessidades especiais;

III - explicitar a concepção pedagógica dos cursos e programas a distância, com apresentação de:

a) os respectivos currículos;

b) o número de vagas proposto;

c) o sistema de avaliação do estudante, prevendo avaliações presenciais e avaliações a distância; e

d) descrição das atividades presenciais obrigatórias, tais como estágios curriculares, defesa presencial de trabalho de conclusão de curso e das atividades em laboratórios científicos, bem como o sistema de controle de frequência dos estudantes nessas atividades, quando for o caso.

Dentre as orientações para os projetos pedagógicos dos cursos a distância, destaca-se a necessidade dos momentos presenciais no que se refere aos processos avaliativos, estágios, atividades práticas e trabalhos de conclusão de curso. Considerando um processo pedagógico mais amplo, os momentos presenciais visam a garantir a melhor execução das atividades de avaliação da aprendizagem do educando, considerando a natureza do curso e suas especificidades. Carneiro, M. (2013) afirma que:

O legislador foi taxativo ao definir os parâmetros para a avaliação, devendo ser realizada por meio de exames presenciais, de responsabilidade da instituição credenciada para ministrar o curso e de acordo com procedimentos e critérios definidos no projeto de autorização. Em qualquer caso, os exames deverão avaliar competências descritas nas diretrizes curriculares nacionais, quando for o caso, bem como conteúdos e habilidades que cada curso se propõe a desenvolver. (p. 531)

O referido autor acrescenta que a LDB caminha na direção de reforçar a relevância social dos sistemas de EaD; mas, segundo ele, não se trata de substituir o sistema 'presencial', pelo contrário, trata-se de oferecer alternativas de reforço aos processos de aprendizagem presencial.

Estou de acordo com a ideia de Carneiro, M. (2013) e acrescento que a EaD não vem somente como uma alternativa ao processo de aprendizagem presencial, mas traz uma nova concepção metodológica, ressignificando os papeis dos sujeitos que protagonizam o processo de ensino e aprendizagem.

A partir dos dispositivos legais, a EaD garante a legitimação suficiente para ampliar a sua oferta rumo à democratização do acesso ao ensino. Embora seja visível o crescimento da EaD, o 
processo de expansão não garante em si o seu caráter democrático, tendo em vista que ainda existem determinadas camadas da sociedade sem acesso aos níveis mínimos dos sistemas de ensino.

\subsubsection{Números atuais da EaD}

Em outubro de 2014, a Associação Brasileira de Educação a Distância (ABED) divulgou o Censo sobre EaD no Brasil no ano de 2013. O levantamento consultou 309 instituições de todo o país, entre formadoras em vários níveis e fornecedores de produtos e serviços para este ambiente. As instituições pesquisadas respondem por mais de 15 mil cursos e quase 4 milhões de alunos. De forma geral, o relatório destacou que a $\mathrm{EaD}$ vive um bom momento, e as instituições do ambiente da EaD estão muito otimistas.

O Quadro 2 demonstra o otimismo das instituições em relação ao crescimento das matrículas em cursos.

\section{Quadro 2: Evolução das matrículas em cursos, segundo a percepção dos respondentes}

\begin{tabular}{|c|c|c|c|c|c|c|c|c|c|c|c|c|}
\hline \multirow[t]{3}{*}{ Situação } & \multicolumn{12}{|c|}{ \% média } \\
\hline & \multicolumn{2}{|c|}{$\begin{array}{l}\text { Totalmente a } \\
\text { distância }\end{array}$} & \multicolumn{2}{|c|}{ Semipresencial } & \multicolumn{2}{|c|}{$\begin{array}{l}\text { Disciplinas } \\
\text { EAD }\end{array}$} & \multicolumn{2}{|c|}{$\begin{array}{l}\text { Livres não } \\
\text { corporativos }\end{array}$} & \multicolumn{2}{|c|}{$\begin{array}{l}\text { Livres } \\
\text { corporativos }\end{array}$} & \multicolumn{2}{|l|}{ Total } \\
\hline & $\begin{array}{l}2013 / \\
2014\end{array}$ & $\begin{array}{l}2014 / \\
2015\end{array}$ & $\begin{array}{l}2013 / \\
2014\end{array}$ & $\begin{array}{l}2014 / \\
2015\end{array}$ & $\begin{array}{l}2013 / \\
2014\end{array}$ & $\begin{array}{l}2014 / \\
2015\end{array}$ & $\begin{array}{l}2013 / \\
2014\end{array}$ & $\begin{array}{l}2014 / \\
2015\end{array}$ & $\begin{array}{l}2013 / \\
2014\end{array}$ & $\begin{array}{l}2014 / \\
2015\end{array}$ & $\begin{array}{l}2013 / \\
2014\end{array}$ & $\begin{array}{l}2014 / \\
2015\end{array}$ \\
\hline Aumento & $\begin{array}{l}39 \\
(59 \%)\end{array}$ & $\begin{array}{l}55 \\
(83 \%)\end{array}$ & $\begin{array}{l}20 \\
(64 \%)\end{array}$ & $\begin{array}{l}27 \\
(87 \%)\end{array}$ & $\begin{array}{l}17 \\
(58 \%)\end{array}$ & $\begin{array}{l}23 \\
(82 \%)\end{array}$ & $\begin{array}{l}53 \\
(70 \%)\end{array}$ & $\begin{array}{l}59 \\
(78 \%)\end{array}$ & $\begin{array}{l}34 \\
(66 \%)\end{array}$ & $\begin{array}{l}43 \\
(82 \%)\end{array}$ & $\begin{array}{l}163 \\
(64 \%)\end{array}$ & $\begin{array}{l}207 \\
(82 \%)\end{array}$ \\
\hline Diminuição & $\begin{array}{l}14 \\
(21 \%)\end{array}$ & \begin{tabular}{|l}
4 \\
$(6 \%)$
\end{tabular} & $\begin{array}{l}5 \\
(16 \%)\end{array}$ & $\begin{array}{l}2 \\
(6 \%) \\
\end{array}$ & $\begin{array}{l}5 \\
(17 \%)\end{array}$ & $\begin{array}{l}1 \\
(3 \%)\end{array}$ & $\begin{array}{l}5 \\
(6 \%)\end{array}$ & $\begin{array}{l}3 \\
(4 \%)\end{array}$ & $\begin{array}{l}7 \\
(14 \%)\end{array}$ & $\begin{array}{l}3 \\
(6 \%)\end{array}$ & $\begin{array}{l}36 \\
(14 \%)\end{array}$ & $\begin{array}{l}13 \\
(5 \%)\end{array}$ \\
\hline Manutenção & $\begin{array}{l}13 \\
(20 \%)\end{array}$ & $\begin{array}{l}7 \\
(11 \%)\end{array}$ & $\begin{array}{l}6 \\
(19 \%)\end{array}$ & $\begin{array}{l}2 \\
(6 \%)\end{array}$ & $\begin{array}{l}7 \\
(24 \%)\end{array}$ & $\begin{array}{l}4 \\
(14 \%)\end{array}$ & $\begin{array}{l}17 \\
(22 \%)\end{array}$ & $\begin{array}{l}13 \\
(17 \%)\end{array}$ & $\begin{array}{l}10 \\
(19 \%)\end{array}$ & $\begin{array}{l}6 \\
(11 \%)\end{array}$ & \begin{tabular}{|l}
53 \\
$(21 \%)$
\end{tabular} & $\begin{array}{l}32 \\
(12 \%)\end{array}$ \\
\hline Total $^{*}$ & 66 & 66 & 31 & 31 & 29 & 28 & 75 & 75 & 51 & 52 & 252 & 252 \\
\hline
\end{tabular}

Fonte: ABED 2013, p. 31 
De acordo com os dados, as instituições mais otimistas são as que praticam educação semipresencial ou totalmente a distância ${ }^{10}$, nessas o otimismo é superior a $80 \%$ para o ano de 2015. Esse otimismo se mantêm quando observamos o total. Das 252 instituições que responderam a esse tópico da pesquisa, $82 \%$ delas apontam para o aumento de matrículas no anos de 2014 e 2015, e apenas 5\% acreditam na diminuição.

Com relação ao perfil de estudantes, o censo apontou que a maior parte dos estudantes de cursos superiores têm entre 31 e 40 anos, além de possuir prevalência feminina (56 a 61\%). Outro dado interessante é que a maioria dos estudantes são trabalhadores, informação que confirma o exposto anteriormente por Nunes (2009), sobre o público da EaD ser de adultos. Já os tipos de formação prevalentes são cursos de graduação e pós-graduação, conforme quadro 3.

\section{Quadro 3: Perfil ocupacional dos educandos dos cursos EaD}

\begin{tabular}{|c|c|c|c|c|c|}
\hline \multirow[t]{2}{*}{ Cursos } & \multirow[t]{2}{*}{ Nível } & \multicolumn{3}{|c|}{ Quantidade de respostas } & \multirow[t]{2}{*}{ Total } \\
\hline & & $\begin{array}{l}\text { Somente } \\
\text { estuda }\end{array}$ & $\begin{array}{l}\text { Estuda e } \\
\text { trabalha }\end{array}$ & $\begin{array}{l}\text { Estuda e está } \\
\text { desempregado }\end{array}$ & \\
\hline \multirow{5}{*}{$\begin{array}{l}\text { Regulamentado } \\
\text { totalmente a } \\
\text { distância }\end{array}$} & EJA & 5 & 11 & 0 & 16 \\
\hline & Ensino profissionalizante & 2 & 26 & 0 & 28 \\
\hline & Superior graduação & 0 & 41 & 1 & 42 \\
\hline & Superior pós-graduação & 0 & 41 & 0 & 41 \\
\hline & $\begin{array}{l}\text { Disciplina obrigatória em } \\
\text { qualquer nível }\end{array}$ & 0 & 2 & 0 & 2 \\
\hline \multicolumn{2}{|l|}{ Total } & 7 & 121 & 1 & 129 \\
\hline
\end{tabular}

Fonte: ABED 2013, p. 23

O quadro 3 revela que, em geral, os estudantes que "somente estudam" estão realizando o curso a distância em nível de Educação de Jovens e Adultos (EJA); já os estudantes que estudam e trabalham, buscam a EaD para estudos em nível de cursos superiores de graduação e pósgraduação. Esse dado confirma o crescimento da $\mathrm{EaD}$ em nível de formação superior, principalmente entre os alunos que estudam e trabalham.

\footnotetext{
${ }^{10}$ A tabela também traz dados dos cursos livres, que podem ser definidos como cursos de curta/média duração que contribuem para a capacitação, aperfeiçoamento e desenvolvimento das habilidades dos alunos e profissionais nas mais diferentes áreas de conhecimento.
} 
O infográfico a seguir sintetiza as informações expostas anteriormente, nos fazendo entender a situação atual da EaD no Brasil.

\section{Figura 1 - EaD no Brasil}

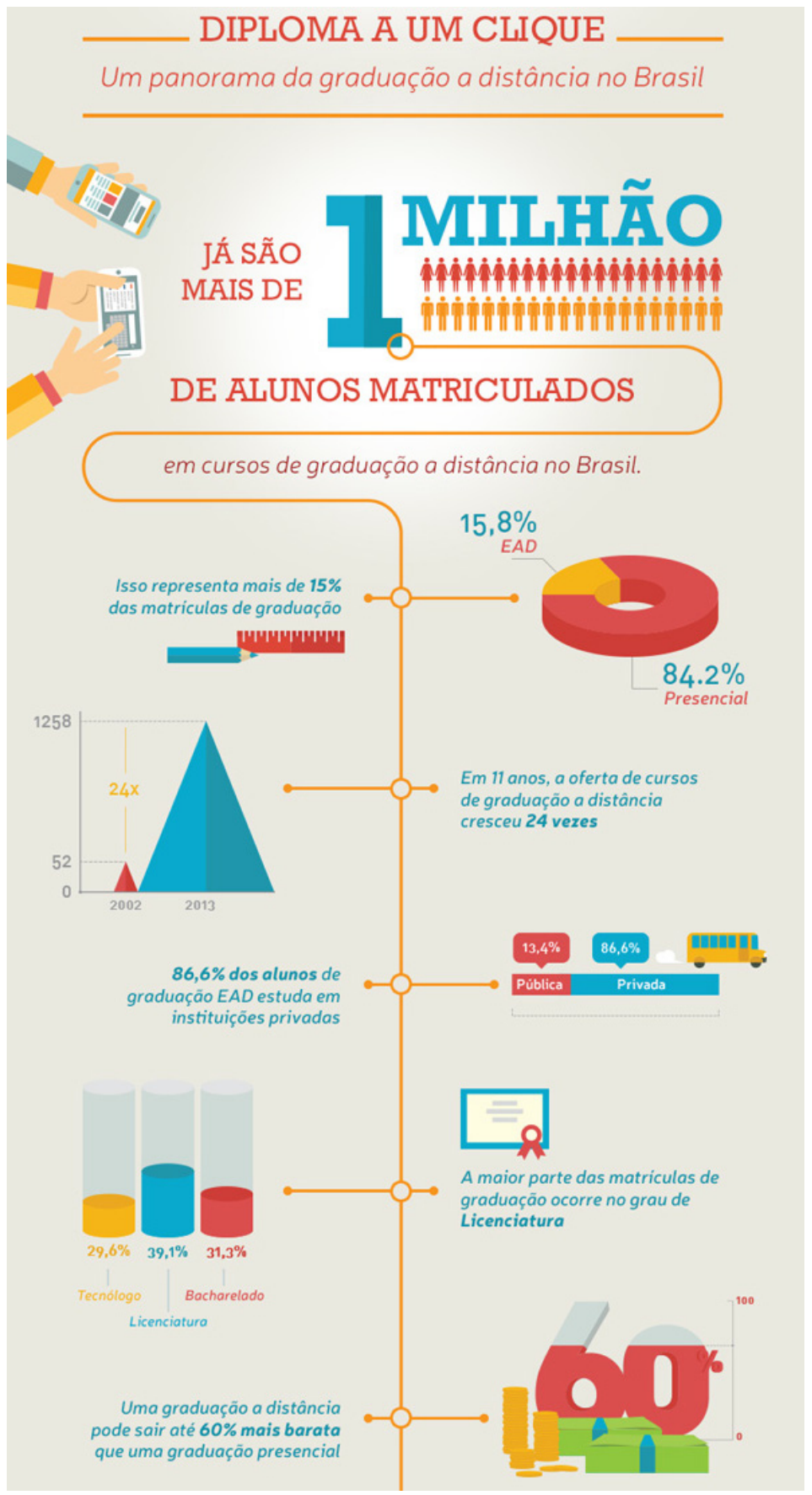




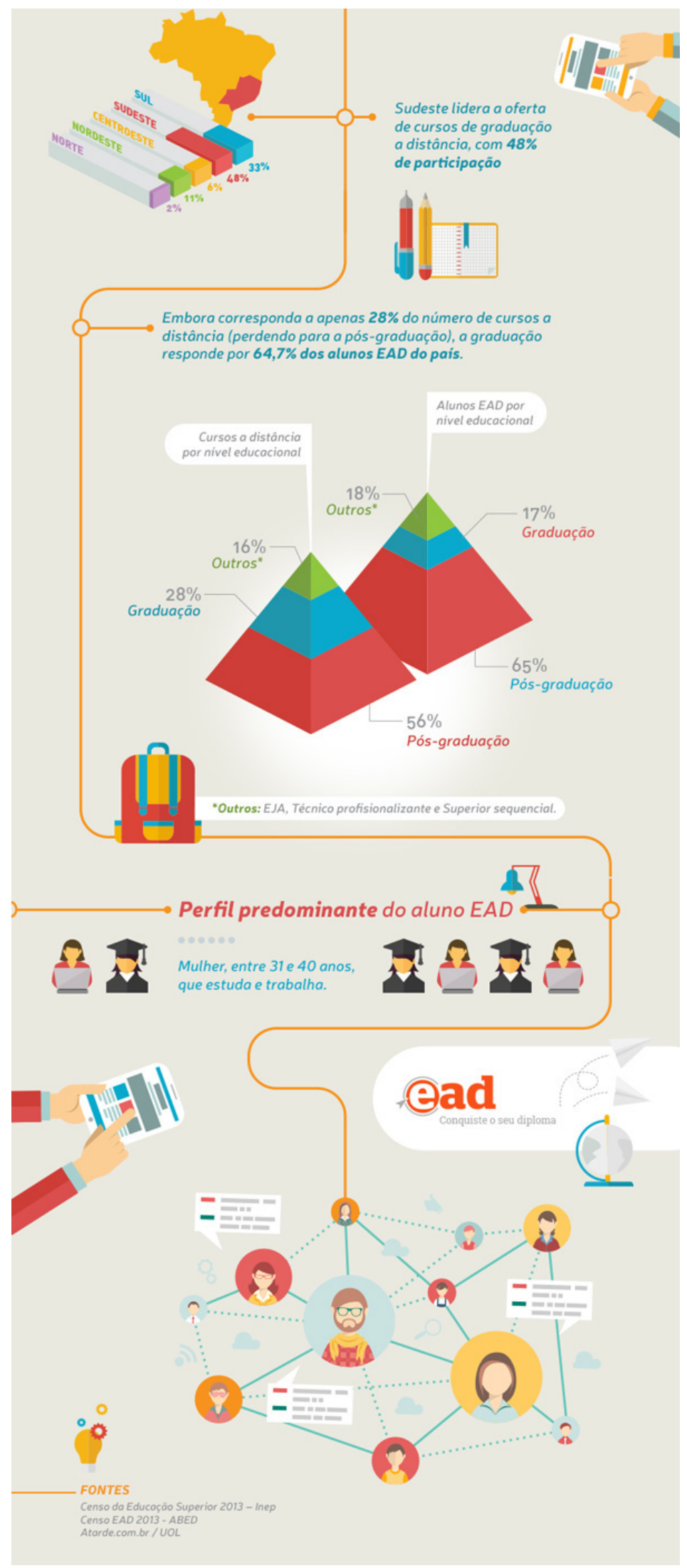

Fonte: www.ead.com.br 
O infográfico foi retirado de um site que oferece cursos EaD, por isso o título "Diploma a um clique" aparece na intenção de vender a formação como um mero "produto", nos remetendo a um pensamento difundido de que a EaD é fácil e possui uma formação aligeirada.

De acordo com a ABED, os cursos de licenciatura aparecem com uma participação significativa de $9,65 \%$ de todos os cursos a distância. Se forem considerados apenas os cursos de graduação a distância, o infográfico acima aponta que os de licenciatura chegam a 39,1\% do total. Portanto, a cada dia mais estamos formando mais professores na modalidade à distância, informação que merece destaque por se tratar de multiplicadores de conhecimento.

A partir do site do MEC, foi possível rastrear a quantidade de instituições hoje que ofertam o curso de licenciatura em língua espanhola na modalidade EaD. No cenário total, hoje temos 113 instituições de ensino ativas que ofertam cursos de licenciatura em Letras (independente da língua) na modalidade EaD. Quando filtramos para a licenciatura em língua espanhola, aparecem 31 instituições cadastradas e ativas em todo o Brasil. Dessas 31 instituições, apenas 16 ofertam a licenciatura apenas em língua espanhola, as outras 15 ofertam uma licenciatura dupla, em língua espanhola e portuguesa.

De acordo com a legislação vigente, a licenciatura em Letras pode ter várias habilitações, autorizadas e reconhecidas na forma da lei, mas para a primeira habilitação a carga horária mínima é de $2.800 \mathrm{~h}$, a ser integralizada em, no mínimo, três anos letivos, como permite a Resolução CNE/CP no 2/2002. O licenciado em Letras, para obter diploma em nova habilitação, deverá cursar, pelo menos, mais $800 \mathrm{~h}$ em cada habilitação posterior à primeira (FRAUCHES 2011).

Quanto à questão tecnológica, tema que será discutido adiante, o Censo aponta que as instituições estão empenhadas em tornar cada vez mais moderna e viável a modalidade de ensino a distância, percebendo então que essa é extremamente dependente da interface tecnológica. No entanto, a interface tecnológica em si não terá grandes efeitos se não houver uma proposta pedagógica que lhe dê o suporte necessário, considerando o contexto e os fundamentos da EaD.

\subsubsection{EaD, tecnologias e o ensino de línguas}

De acordo com Paiva (2013), a importância do uso das tecnologias é ressaltada diariamente na imprensa, nos artigos e livros acadêmicos e corporativos. A autora cita o exemplo 
de um texto produzido para a Apple por Wellings e Levine em 2009. No texto apareceriam os vários benefícios da tecnologia que esses autores consideram estar na base das habilidades para 0 século 21. O entendimento é de que as NTIC ampliam o acesso à educação, às comunidades virtuais e aos especialistas; encorajam a inclusão; apoiam o desenvolvimento do aprendiz; engajam os aprendizes na aprendizagem e na criação de conteúdo; possibilitam inovações metodológicas; facilitam a instrução diferenciada; e ampliam o período diário para aprendizagem (PAIVA 2013).

Nesse contexto de NTIC é que passamos a utilizar o computador e a Internet como ferramentas de aprendizagem. No entanto, Crawford 2008, citado por Leffa 2009 p. 156, afirma que "uma coisa que o computador faz melhor do que qualquer outra é a interatividade. $\mathrm{Na}$ verdade, o computador não apenas faz melhor; o computador é a única mídia capaz de fornecer interatividade. ${ }^{11}$ " Essa ferramenta surge dando um outro olhar e possibilidade para o processo de ensino-aprendizagem por meio de ferramentas tecnológicas. No entanto, Paiva (2015), destaca que o homem está preso em uma constante relação dialética entre a adesão e a crítica ao novo. Ao surgir uma nova tecnologia, ele passa, primeiramente, por um processo de rejeição e desconfiança. Aos poucos, a tecnologia começa a fazer parte das atividades e por fim há uma normalização, em que a tecnologia se integra às práticas pedagógicas e deixa de ser algo temido. Foi o que ocorreu com outras tecnologias, tais como o papel, livro, materiais de áudio e vídeo, computadores e Internet; e é neste último contexto em que aparece o CALL ${ }^{12}$ (Aprendizagem de Língua Mediada pelo Computador $\left.{ }^{13}\right)$.

De acordo com García, G. (2005), que prefere utilizar a sigla ELAO ${ }^{14}$, o CALL ou ELAO é a disciplina científica que tem como objetivo o estudo da integração do microcomputador no processo de ensino e aprendizagem de línguas, preferencialmente estrangeiras. Oliveira (2013) apresenta o desenvolvimento do CALL, trazendo um panorama sobre a sua criação e as

\footnotetext{
${ }^{11}$ Leffa (2009) afirma que para ser interativo é preciso aprender a fazer mais com menos texto, mas isso não significa necessariamente substituir texto por gráficos, áudio e vídeo. Uma possibilidade, apresentada em seu texto, é substituir gradativamente os textos mais longos, usados nas atividades de auto-estudo, por textos mais curtos, às vezes do comprimento de uma frase; unindo a isso atividades como ler e clicar, recebendo feedback automático à medida que se avança na atividade, como se estivesse seguindo uma trilha.

${ }^{12}$ Computer Assisted Language Learning

${ }^{13}$ Todas as traduções presentes neste trabalho foram feitas por mim.

${ }^{14}$ Enseñanza de Lenguas Asistida por Ordenador (Ensino de Línguas por meio do Computador)
} 
diferentes etapas e denominações que ganhou por diversos autores. Nesse contexto, Pennington 1996 (apud OLIVEIRA 2013, p. 200) afirma que "[o CALL] pode ser uma fonte ilimitada e rica de input na LE combinando informações linguísticas, visuais e sonoras que, por sua vez, atendem aos diversos estilos de aprendizagem dos aprendizes".

Ainda sobre o CALL, a citação de Bax (2003 apud OLIVEIRA 2013, p. 199), que se segue, é bem relevante para essa discussão de novas tecnologias no ensino:

o CALL será normalizado quando os computadores forem tratados sempre como algo secundário à aprendizagem em si, quando as necessidades dos alunos forem cuidadosamente analisadas em primeiro lugar e, então, o computador será usado para atender tais necessidades.

Dessa forma, fica claro como o avanço das tecnologias permite novos recursos para o melhoramento do processo de ensino de línguas, e isso se combina com a EaD. Contudo, apesar dos avanços, é necessária atenção, concordando com a citação de Bax (2003), pois a tecnologia deve atender as necessidades dos aprendizes. Apenas dessa forma a aprendizagem de línguas mediadas por computador será efetiva.

Importante ressaltar que, antes do CALL, falava-se em PLATO (Programmed Logic for Automatic Teaching Operations) ${ }^{15}$. Segundo Levy (1997 apud PAIVA 2015), o ensino de línguas mediado por computador teve início com o projeto PLATO, em 1960, na Universidade de Illinois. PLATO usava uma ferramenta de autoria, o tutor, que permitia desenvolver exercícios de gramática e vocabulário com feedback automático. O projeto oferecia instrução mediada por computador para várias línguas. No entanto, segundo Leffa (2006), o PLATO enfatizava o ensino da gramática, dentro de uma abordagem estruturalista com muita repetição de exercícios de manipulação das estruturas básicas da língua, buscando a formação de "hábitos linguísticos", devido à concepção behaviorista da época, pois a língua era vista essencialmente como a criação de novos automatismos. Apesar das limitações do PLATO, ele apresenta a sua importância histórica.

Parece evidente que os avanços tecnológicos, no que se referem ao ensino de línguas, buscam sair de situações prontas, com feedbacks automáticos, para situações contextualizadas em que as necessidades reais dos alunos, dentro do processo, são questionadas. Com base nessa

\footnotetext{
${ }^{15}$ Lógica Programada para Operações Automáticas de Ensino
} 
afirmação, passa a ser relevante analisar as diferentes possibilidades de aprendizagem dentro do contexto virtual.

Nesse sentido, Paiva (2001), traça um panorama do crescimento da Web e as possibilidades no contexto de ensino de línguas. A autora afirma que a ferramenta inicial da Internet foi o correio eletrônico, que estava associado à possibilidade de transferência de arquivos de texto através de acesso remoto. Depois disso, aparece a World Wide Web (WWW) que reúne informações em forma de texto, imagens, vídeo e som, de forma isolada ou multimídia.

A tecnologia continuou avançando e, com o passar dos anos, surgiram novas formas de comunicação e os aprendizes de línguas estrangeiras puderam, então, ter acesso a páginas da Internet e interagir com falantes das línguas por meio de e-mail, listas de discussão e fóruns. Conforme sublinha a autora, "pela primeira vez, temos uma tecnologia que permite experiências linguísticas não artificiais e a língua pode ser entendida como comunicação". (PAIVA 2015)

De acordo com García, G. (2005), o grande boom da Internet afetou de maneira direta o desenvolvimento do CALL, e mais concretamente a aprendizagem de LE, pois a Web possui uma série de usos muito práticos na aprendizagem de LE, conforme descritos a seguir: 1) acesso a dicionários online; 2) participação em tele-debates textuais assíncronos entre especialistas; 3 ) acesso direto a bibliotecas; 4) acesso a numerosas obras em formato eletrônico;

Paiva (2015) ainda afirma que antes o foco era apenas no ensino de escrita e leitura, pois a tecnologia de voz ainda era insipiente. No entanto, a autora afirma que hoje, com a popularização da webcam, já é possível usar tecnologia de vídeo e voz como o Skype $^{16}$ e $\mathrm{OoVoo}^{17}$, como fazem os professores da UNESP no projeto Teletandem Brasil. Outras tecnologias de voz são o podcast $^{18}$ e os voice-blogs ${ }^{19}$.

\footnotetext{
${ }^{16}$ Skype é um software que possibilita comunicações de voz e vídeo via Internet, permitindo a chamada gratuita entre usuários em qualquer parte do mundo.

${ }^{17}$ OoVoo é uma plataforma social para vídeo e bate-papo que permite que os usuários se conectem de maneira instantânea com seus amigos mais próximos por meio de vídeo em alta definição.

${ }^{18}$ Podcast é o nome dado ao arquivo de áudio digital publicado na internet. Também pode se referir a série de episódios (sempre no formato de áudio) de algum programa.

${ }^{19}$ Voice-blog é um site, no formato de blog, que permite gravações de áudio que ficam disponíveis no site.
} 
O Teletandem merece destaque na linha do tempo de recursos para o ensino de línguas, pois foi considerado um projeto inovador, que pode ser definido como a aprendizagem de línguas estrangeiras in-tandem, o qual envolve pares de falantes (nativos ou não nativos) de diferentes línguas trabalhando, de forma colaborativa, para aprenderem a língua um do outro.

Ferramentas como Skype e OoVoo, a primeira mais popularizada, permitem interação, já que servem de ponte entre os agentes. Por meio de chamadas de áudio e vídeos os estudantes podem praticar a língua estudada. Em um contexto de curso EaD, a interação nessas ferramentas pode se dar entre tutor/professor e estudante; entre estudantes da mesma turma; ou pode também aparecer em um contexto em que estudantes veteranos podem interagir com os calouros, buscando auxiliá-los na aquisição da língua oral.

Os podcasts e voice-blogs aparecem em um contexto mais "solitário" do aprendiz, em que ele utiliza os áudios para ter contato com a língua oral e pode fazer gravações, produzindo e publicando na Internet seus próprios áudios na língua estrangeira.

Pensar na Web como local para ensino de línguas estrangeiras parece apontar apenas perspectivas positivas, no entanto, vale ressaltar que há vantagens e desvantagens. Paiva (2001) elenca pontos de vantagem e desvantagem de aprendizagem de LE na Web. De acordo com a pesquisadora, os inúmeros sites disponíveis na $W e b$ e todos os recursos, que reúnem imagem e som, criam um ambiente cognitivo que proporciona à mente experiências semelhantes àquelas vividas no nosso dia-a-dia. De acordo com ela, estamos navegando em um "mundo", com muitas informações que nos permitem uma aprendizagem muito grande; porém, em seu quadro comparativo (Quadro 4, reproduzido a seguir) é possível verificar que também há a necessidade de atenção em relação aos recursos oferecidos pela $W e b$. 


\section{Quadro 4 - Vantagens e desvantagens da $\mathbf{W e b}$}

\begin{tabular}{|c|c|}
\hline PONTOS POSITIVOS DA $W E B$ & PONTOS NEGATIVOS DA $W E B$ \\
\hline Variedade de informação & Excesso de informação \\
\hline Possibilidade de atualização constante & $\begin{array}{l}\begin{array}{l}\text { Ausência de atualização em algumas } \\
\text { homepages }\end{array} \\
\end{array}$ \\
\hline Ambiente multimídia: imagem, som, vídeo & $\begin{array}{l}\text { Lentidão no carregamento da informação } \\
\text { proporcional à quantidade de recursos }\end{array}$ \\
\hline Facilidade de navegação & $\begin{array}{l}\text { Necessidade de atualização constante de } \\
\text { softwares }\end{array}$ \\
\hline Diversidade de material & Nem todo material é de boa qualidade \\
\hline Possibilidade de escolha de informação & Nem toda informação é confiável \\
\hline $\begin{array}{l}\text { Responsabilidade individual na escolha de } \\
\text { informação }\end{array}$ & Excesso de opções dificultando a escolha \\
\hline $\begin{array}{l}\text { Cada um interage com a informação de } \\
\text { acordo com seu próprio ritmo }\end{array}$ & Leitura de muita informação na tela é cansativa \\
\hline Gratuidade da informação & O preço do impulso telefônico é caro \\
\hline Fomento a educação continuada & Nem todos os cursos são gratuitos \\
\hline Rapidez no acesso à informação & $\begin{array}{l}\text { Necessidade de refinamento na busca das } \\
\text { informações. As informações nem sempre são } \\
\text { localizadas }\end{array}$ \\
\hline Acesso a textos em processo de construção & $\begin{array}{l}\text { Algumas homepages ficam eternamente em } \\
\text { construção }\end{array}$ \\
\hline Uso por tempo ilimitado & $\begin{array}{l}\text { Volatilidade da informação. Algumas páginas } \\
\text { desaparecem rapidamente }\end{array}$ \\
\hline Possibilidade de acesso aos autores & Algumas homepages são anônimas \\
\hline $\begin{array}{l}\text { Orientação da leitura através de mapas de } \\
\text { navegação }\end{array}$ & Algumas homepages são mal organizadas \\
\hline Possibilidade de leitura não linear & $\begin{array}{l}\text { A viagem através de hipertextos pode desviar a } \\
\text { atenção do objetivo principal }\end{array}$ \\
\hline
\end{tabular}

Fonte: PAIVA 2001, p. 99

Alguns dos recursos apresentados no quadro 4, como a questão de se gastar "impulsos do telefone" já fazem parte do passado de várias pessoas. No entanto, ainda temos um contexto em que mais da metade da população não possui acesso à Internet no Brasil. Em 2013 a pesquisa do Instituto Brasileiro de Geografia e Estatística (IBGE) investigou a utilização da Internet por meio de diversos equipamentos (microcomputador, telefone móvel celular, tablet e outros) e concluiu que 85,6 milhões (49,4\% da população), considerando pessoas de 10 anos ou mais de idade, utilizaram a Internet, pelo menos uma vez, no período de 90 dias que antecederam ao dia da entrevista. Isso demonstra um avanço no uso e acesso à Internet e às tecnologias no país, mas esse acesso ainda não faz parte da realidade de muitos brasileiros. 
Outros pontos salientados por Paiva, quanto às vantagens e desvantagens da $W e b$, como páginas anônimas, sem atualização ou até com informações desencontradas, merecem uma atenção especial durante a navegação na $W e b$. Como podemos perceber, a aprendizagem solitária, apesar de interessante, pode ser problemática. Sendo assim, um profissional como mediador do processo de aprendizagem pode ajudar o estudante nas suas escolhas por páginas de conteúdos atualizados e confiáveis. Por essa razão que um projeto pedagógico sólido antecede o uso das tecnologias no processo de formação via Web. A mediação irá prever momentos de orientação aos alunos quanto ao acesso à informação e transformação em conhecimento útil.

García, M. (2005) apresenta leitura similar à de Paiva (2001) sobre essas vantagens e desvantagens. García, M. (2005) (com base em MARQUÉS 1999) aponta as seguintes vantagens no uso da Web: 1) globalização da informação; 2) desenvolvimento de habilidades de comunicação interpessoal e de autoaprendizagem; 3) proporciona uma dupla interatividade com os materiais e com as pessoas; 4) motivação e permissão da aproximação interdisciplinar e intercultural de temas. Já as desvantagens expostas são: 1) perda de tempo para localizar informação; 2) muitas informações são pouco confiáveis; 3) falta de atualização de muitas páginas. Em ambas visões é notória a preocupação com a confiabilidade do conteúdo na $W e b$ e o tempo que se pode perder para se localizar informações.

Já para Marín (2005), as páginas Web estimulam a interpretação dos conteúdos e a interação entre eles, se convertendo em um meio para pesquisas, devido à riqueza dos materiais da rede; além disso, as aulas (no caso dos cursos online) podem orientar-se em direção a novos caminhos, possibilitando aprofundar o conhecimento de um tema concreto. Outra observação feita pelo mesmo autor, agora destacando um ponto que poderia ser considerado negativo, é que, no caso da $W e b$, é cada vez mais necessário levar em consideração que os problemas de direitos autorais e de propriedade intelectual na Internet são mais frequentes, e que este tipo de curso representaria o fim do livro do tipo estático, com o início de um novo tipo de texto, textos dinâmicos e baseados em temas relacionados.

No contexto da Internet, questões relacionadas ao plágio e aos direitos autorais são latentes. Silva (2008, p. 357) questiona a definição de autor no contexto atual, caracterizado por "uma sociedade em que a tecnologia digital transforma a linguagem num elo virtual entre o homem e o mundo." De acordo com a autora, é necessário reconfigurar, dentro da academia, as 
concepções de pesquisa, leitura, produção e autoria; estimulando criações na comunidade acadêmica que possam contribuir com o desenvolvimento intelectual, social e educacional.

Ainda de acordo com Marín (2005), as transformações nas tecnologias foram ao encontro das teorias de aquisição de línguas, desde um ensino totalmente conduzido até o ensino de forma comunicativa, tópico que será exposto a seguir. Dessa forma, enquanto que nos dias de tecnologia audiolingual o computador administrava principalmente exercícios mecânicos, mais tarde, seguindo a metodologia comunicativa, o computador serviu para dar aos estudantes ocasiões e situações de interação. Antes de adentrar o campo do ensino comunicativo, é fundamental destacar que o processo de aprendizagem de uma língua está intimamente ligado à motivação, a qual, por sua vez, tem relação com diversos fatores a serem expostos a seguir.

\subsubsection{Motivação e aprendizagem de LE}

Bergillos (2005) afirma que, enquanto que praticamente nenhum fator ambiental impede a aprendizagem das primeiras línguas (entendida aqui como Língua Materna - LM), inclusive em ocasiões adversas, como déficits cognitivos, há o desenvolvimento da linguagem; a aprendizagem de segundas línguas ${ }^{20}$, tanto em circunstâncias naturais como formais, possui seus problemas próprios. Nesse processo, destacam-se traços da pessoa (alguns mutáveis e outros não) que, de forma isolada ou integrada, podem explicar o conhecimento adquirido ${ }^{21}$ ou prever o que se vai adquirir. Outros fatores são cognitivos, como a aptidão (habilidade para assimilar material linguístico descontextualizado e processar a língua com eficácia); e também se incluem os estilos de aprendizagem, que permitem distinguir, entre outras categorias, os alunos analíticos (aqueles que processam a língua por meio de suas características discretas) dos alunos holísticos (aqueles que são levados pelas propriedades significativas das mensagens).

$\mathrm{O}$ autor ainda destaca que, entre esses dois tipos (fatores cognitivos e afetivos), se encontram outros fatores com uma longa tradição de pesquisa, como as estratégias de aprendizagem, entendidas aqui como mecanismos conscientes e inconscientes que os alunos utilizam no processo de aquisição e de uso de uma segunda língua. Há também, nesse bojo, o

\footnotetext{
${ }^{20}$ Mesmo concordando com as diferentes definições de LE e L2, para este trabalho os conceitos não estarão dissociados, tratando, assim, os dois temas como um mesmo sistema.

${ }^{21}$ A preferência de uso do termo "aquisição" ao termo "aprendizagem" é feita pelo autor.
} 
fator idade, relacionado com a existência de um período crítico de aquisição que serviu como pilar fundamental para o desenvolvimento de teorias inatistas de aprendizagem. Por fim, os traços da personalidade (inibição, empatia etc.).

Para Almeida Filho (2005) há inúmeras variáveis no cenário de aprendizagem de línguas, sendo que as diferentes configurações delas propiciam tendências de aprendizagem de tipos muito diversos. Essas variáveis são organizadas em dois blocos: a) as variáveis intrínsecas à pessoa, como as afetivas (ligadas a aspectos de personalidade, atitude e motivação), as físicas (ligadas à condições de saúde, cansaço, idade) e as sócio-cognitivas (ligadas a estratégias conscientes e inconscientes de organizar a experiência do contato linguístico com outros em interação na língua-alvo); e b) as variáveis extrínsecas, como material didático, técnicas e recurso do método, tempo disponível para o estudo, condições de exposição às amostras de língua, etc.

Essa teoria está relacionada a Krasher, que em 1982 introduz, entre outras hipóteses, a do filtro afetivo. De acordo com Almeida Filho (2005, p. 20) "[o] filtro se constitui em configurações específicas de motivações, fatores de personalidade e atitudes de identificação ou rejeição da cultura que aninha a língua-alvo".

Os fatores afetivos, e mais concretamente a motivação, passaram de um conceito conveniente, e até certo ponto pouco definido, para se converter em um construto de destaque, através de técnicas empíricas que dão lugar a conclusões, generalizações e implicações metodológicas para a aprendizagem (BERGILLOS 2005).

Bergillos (2005) destaca ainda que a motivação se concebe como um construto hipotético, definido por ele como elemento que aglutina uma série de características, observáveis e não observáveis, que podem ser apontadas como as causas de um fenômeno. Assim, a motivação, na condição de construto hipotético, explica os processos mentais que instigam e sustentam a atividade dirigida a um objetivo. Quando o objetivo é a aprendizagem de uma LE, a motivação explica a ação, a intencionalidade e a tomada de decisões a respeito da aquisição e do uso de um novo código linguístico. Portanto, a motivação se apresenta através de comportamentos perceptíveis, como a posição do corpo, o foco da visão em sala de aula, a seleção de atividades no tempo livre, entre outros). No caso da $\mathrm{EaD}$, alguns desses comportamentos não são perceptíveis, por estudante e professor não estarem presencialmente em um mesmo espaço de aprendizagem, no entanto, outros comportamentos dos estudantes, como a 
presença constante no ambiente virtual, questionando o professor, buscando saber mais sobre o assunto, são posturas que indicam uma motivação no contexto da EaD.

Para Michelon (2003), a motivação parece não ser a soma de uma série de fatores internos e externos, mas a soma de vários fatores internos, que dependem de características individuais influenciadas pelo meio e que levam o aprendiz a querer aprender.

O impacto da motivação na ativação dos processos de aquisição desencadeia uma atuação dos sujeitos diferente tanto de forma quantitativa (em termos de intensidade) como qualitativa em função dos tipos de mecanismos de processamento da língua que se está aprendendo. Nesse sentido, alguns estudos vão além, vinculando a motivação com a base física da aprendizagem e apontando que existem áreas cerebrais que, em contato com um input linguístico interessante ou situações de aprendizagem satisfatórias, se mobilizam na aquisição de uma nova língua (BERGILLOS 2005).

Segundo Crookes e Schmidt (1991 apud MICHELON 2003 p. 02) "a motivação se torna importante na medida em que controla o engajamento e a persistência nas tarefas de aprendizagem". Por isso, Bergillos (2005) aponta que os efeitos do comportamento motivado se fazem sentir em todos os níveis linguísticos. No caso do nível fonológico, por exemplo, estudos apontam que o grau de motivação resulta como um dos fatores mais relevantes nos níveis de correção de pronúncia da língua a ser aprendida, acima, inclusive, de fatores como a duração da estadia em uma comunidade de uso da língua.

No entanto, o fator de contato não pode ser excluído, ele é parte do processo motivacional, pois estudos concluíram que a carência de contato com a comunidade ou a cultura da língua a ser aprendida resultam em indicadores deficientes nos níveis motivacionais. A afirmação de Dõrnyei (1990 apud MICHELON 2003 p. 05) vai ao encontro da afirmação anterior ao expor que a aquisição de LE se dá em contextos em que "a aprendizagem está, no mínimo, parcialmente incorporada ao meio onde a língua-alvo é falada, ou seja, seu domínio se dá através da exposição direta à língua ou pela instrução formal acompanhada da interação frequente com a comunidade linguística alvo."

A motivação para se aprender uma língua e o contato direto com ela têm impacto no processo identitário. Nesse sentido, pensando na natureza e funções da língua, Michelon (2003) afirma que a motivação para aprender LE se reveste de características especiais devido a essas natureza e funções específicas da língua em si. A autora cita Dõrnyei (1998, p.118), que afirma 
que a língua é, ao mesmo tempo, "a) um sistema de códigos de comunicação" e, como tal, é uma disciplina escolar, "b) parte integrante da identidade do indivíduo" e também "c) o mais importante canal de organização social incorporado na cultura da comunidade onde é usada".

Nesse contexto, Begillos (2005) faz a distinção entre LE e L2 no contexto de identidade e comunicação, afirmando que em uma situação de aprendizagem de L2 o novo código linguístico pode alterar as bases identitárias do indivíduo, e se transformar em uma língua de identificação, enquanto que no caso de uma LE o uso do novo código responde a razões pragmáticas ou de conveniência conjuntural, portanto, o novo código é uma língua de comunicação. Entendo que no processo de formação de professores, em que há o processo de aprender a língua para ensinar, esses dois tipos de língua (língua de identificação e língua de comunicação) se misturam, e a LE aprendida pelo professor não seria apenas uma língua de comunicação, conforme afirma o autor, mas, sim, também uma língua de identificação, pois tem relação direta com a sua identidade de professor de LE.

Neste primeiro bloco, foram expostas informações sobre $\mathrm{EaD}$ e o ensino de línguas estrangeiras com o apoio de tecnologias, além do papel da motivação na aprendizagem de uma LE; adiante serão trazidas informações sobre oralidade, tema central desta pesquisa.

\subsection{A ORALIDADE NO ENSINO DE LÍNGUAS ESTRANGEIRAS}

Para adentrar o campo da oralidade, objeto de análise deste estudo, faz-se necessário introduzir o tema da competência comunicativa, tendo em vista que se trata de um tema que tem servido de apoio para as novas teorias sobre como ensinar línguas. De acordo com Pretto (2010), foi a partir de 1972 que começaram a aparecer, no campo de ensino de línguas, muitos trabalhos em que os termos "comunicação" e "competência comunicativa" se apresentavam de maneira persistente. Dessa forma, não se pode dissociar oralidade de comunicação e, portanto, de competência comunicativa.

Em termos de definição, Iragui (2005) afirma que a competência comunicativa é um dos conceitos mais importantes na Linguística Aplicada (LA), tanto no estudo da aquisição de segundas línguas como, em um nível mais prático, o ensino de línguas; no entanto, a autora afirma que a importante difusão do conceito de competência comunicativa nos estudos de aquisição e ensino de línguas está relacionado diretamente com a distinção realizada por Chomsky (1965). 
A autora destaca que, para Chomsky, a competência é o conhecimento que o falanteouvinte tem da língua, enquanto que a atuação é o uso real da língua em situações concretas. Destaca ainda que Chomsky está interessado em estudar a competência, não a atuação. Portanto, parte do estudo da língua como sistema, e não está interessado no uso da linguagem ou na aquisição e ensino de línguas; seu interesse está voltado para o desenvolvimento em uma teoria linguística centrada principalmente nas regras gramaticais. É a partir desse contexto que surge a competência comunicativa e consequentemente o ensino comunicativo de línguas, numa vertente relacionada ao uso da linguagem, à atuação.

Nesse sentido, Gargallo (1999 apud PRETTO 2010) afirma que a aplicação do conceito de competência comunicativa ao ensino de línguas no início dos anos 70 significou uma mudança de orientação no ensino, pois ele aborda o estudo da língua em uso e não como sistema descontextualizado. Isso se mostra como novidade, pois até aquele momento o estruturalismo prevalecia, ou seja, o foco estava em um modelo que entendia a língua como sistema hierarquizado de estruturas linguísticas, e o condutismo psicológico com a sua visão de aprendizagem como resultado do binômio estímulo-resposta. Assim, tanto no método da gramática e tradução quanto no método estruturalista, a competência gramatical era o único objetivo do ensino de línguas estrangeiras. Somente a partir da década de 70 outras habilidades passaram a ser valorizadas, sem que a competência gramatical, no entanto, perdesse a sua importância.

Para Almeida Filho (2008), o ensino comunicativo de LE é aquele que está pautado na organização das experiências de aprender em termos de atividades/tarefas de real interesse e/ou necessidade do aluno para que ele se capacite a usar a língua-alvo para realizar ações de verdade na interação com outros falantes-usuários dessa língua. O mesmo autor afirma que ser comunicativo no ensino de LE é ter uma postura profissional coerente com um conjunto de pressupostos considerados comunicativos.

Ser comunicativo é diferente de estar comunicativo temporariamente para realizar uma atividade com os alunos. Ser comunicativo não é necessariamente ser extrovertido ou simpático. Não é, da mesma forma, sinônimo de ser informativo ao ensinar uma língua. Nem é equivalente a ensinar língua oral. (ALMEIDA FILHO 2008, p. 45 - grifo meu) 
Importante destacar que, como afirma o autor, competência comunicativa não pode ser equivalente a ensinar língua oral, na realidade, o que se espera é aprender a usar a língua de forma eficiente em uma situação real de comunicação; mas, ao aprendermos uma língua, não se pode negar que a produção oral é bastante valorizada. Platero (2002) afirma que a importância da oralidade não é algo a se duvidar, "talvez baste dizer que uma pessoa é denominada 'falante' de uma determinada língua, ou que, quando queremos saber se alguém tem conhecimentos de inglês, por exemplo, perguntamos se ela 'fala' essa língua".

Seguindo esse mesmo pensamento, Ferreira (2012) afirma que é possível se verificar algumas representações em relação à oralidade ${ }^{22}$, por exemplo: a oralidade como objeto de desejo; a oralidade como possibilidade de ascensão profissional; e a oralidade como elemento legitimador do "saber" da língua estrangeira. Esse último aspecto, conforme já exposto por Platero (2002), está relacionado ao processo de enunciar oralmente em LE, pois, de acordo com as pesquisas de Ferreira (2012, p. 46), os estudantes de LE apresentam um entendimento de que a oralidade se sobrepõe sobre as demais, pois, ao elencar as habilidades, as pessoas primeiramente listam a fala, depois, a escrita e, somente depois, a leitura. Ao se declarar falante de uma LE, supõe-se que todas as demais habilidades são "dominadas" pelo indivíduo. Complementando esse entendimento de que aprender LE é saber falar, nessa mesma pesquisa, houve um entendimento por parte dos estudantes de que é necessário fazer "um curso fora da Universidade para aprender algo que não se aprende na universidade. Deflagrando que aprender inglês é aprender a oralidade (não ensinada na universidade)".

\subsubsection{Conceito de oralidade}

Pinilla Gómez (2005), que decide por utilizar o termo expressão oral, trata principalmente da definição, categorização, desenvolvimento e avaliação do tema no contexto de ensino da língua espanhola. Ao trabalhar esse tema, a autora afirma que a expressão oral é uma das atividades de comunicação que se pode desenvolver durante um ato comunicativo e é mediante ela que processamos, transmitimos, intercambiamos e negociamos informação com um ou vários interlocutores.

\footnotetext{
${ }^{22} \mathrm{O}$ autor trabalha com oralidade no ensino de língua inglesa, mas a perspectiva exposta pode ser utilizada para o ensino de qualquer LE.
} 
$\mathrm{Na}$ expressão oral, o objetivo do processo de aprendizagem é o uso da língua para comunicação, dessa forma, a expressão oral engloba tanto aquelas situações comunicativas em que o falante atua sozinho, como na produção de um discurso ou quando deixa uma mensagem em uma secretária eletrônica, como também as situações em que atua alternadamente como falante e ouvinte, com a interação presente em um debate ou em uma entrevista.

Com base nessa definição da autora, fica claro que, para uma efetiva aprendizagem de uma língua, é necessário o desenvolvimento dessa habilidade. Na realidade, a autora afirma que, quando se fala em expressão oral, é necessário pensar na integração das habilidades, já que na comunicação tanto as habilidades produtivas (falar e escrever) como as receptivas (escutar e ler) costumam aparecer de maneira integrada; portanto, cada habilidade pode ser propulsora ou consequência de qualquer uma das outras três, conforme a figura 2:

\section{Figura 2 - As quatro habilidades}

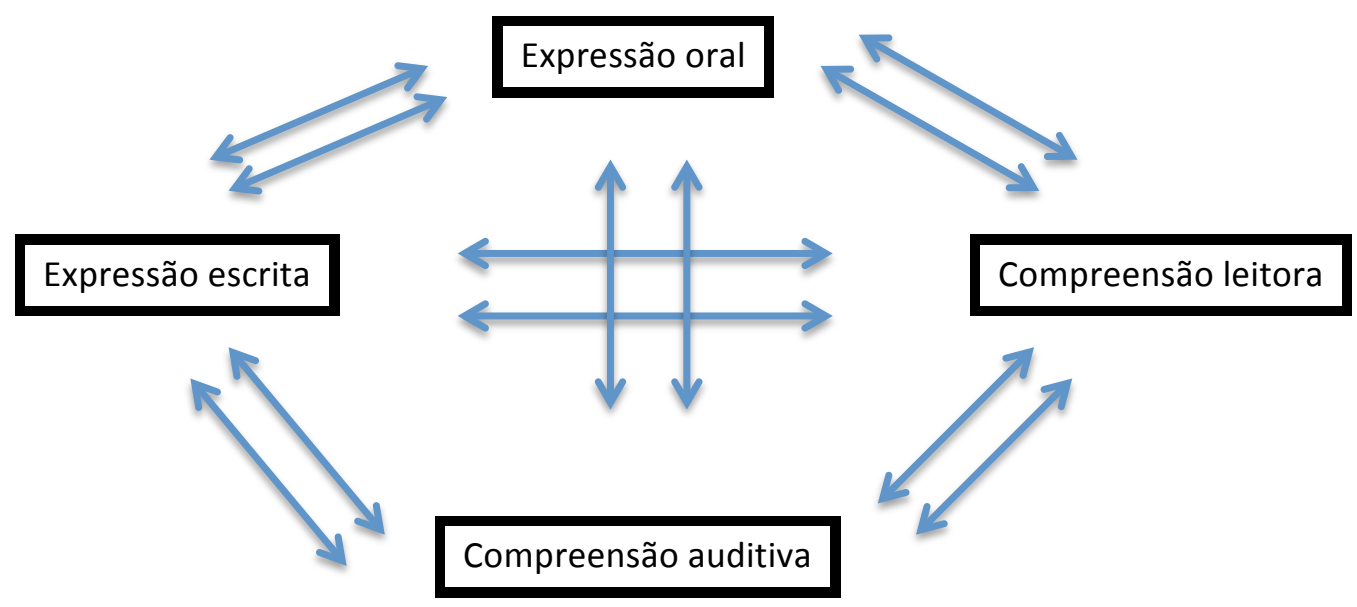

Fonte: PINILLA GÓMEZ 2005, p. 882

Com base na figura 2, fica subentendido que, durante a aprendizagem de uma LE, as quatro habilidades estão sendo adquiridas e desenvolvidas simultaneamente, no entanto, é importante lembrar que cada habilidade possui atividades específicas, que facilitam o seu desenvolvimento.

Considero relevante destacar aqui a relação direta que há entre o processo de oralidade e de compreensão auditiva no contexto de ensino-aprendizagem de LE. Concordo com a autora Pinilla Gómez sobre a influência das habilidades (umas nas outras) no processo de aprendizagem 
e "domínio" de uma LE, no entanto entendo que a relação entre oralidade e compreensão auditiva é mais forte, pois é a partir do processo de input dado pelo ato de compreender é que há a produção oral como consequência.

Nesse sentido, Martínez (2005) afirma que, em geral, nos cursos ou materiais didáticos, as atividades que requerem expressão oral costumam aparecer em último momento da lição ou unidade, uma vez que o aprendiz recebeu suficiente input para ser capaz de produzir língua. Essa informação tem relação direta com a teoria de Vygotsky (1984) exposta por Paiva (2001, p. 100), em que a autora afirma que é através da linguagem e da interação com os outros que os indivíduos vão ampliando seus conhecimentos. "No caso da aprendizagem de uma língua, a interação é imprescindível, pois a língua é por sua natureza social. Aprende-se uma língua para se comunicar com os outros, seja por meio escrito ou por meio oral."

Para Martínez (2005), a oralidade e a compreensão auditiva são as mais difíceis de se dominar num contexto de aprendizagem de LE, pois essas habilidades orais, por causa dos traços próprios da oralidade (as variedades dialetais, sociais e individuais no sotaque, a entonação e a pronúncia), e pelo fato de que em situações de uso real da língua requerem a intervenção imediata do falante-ouvinte, apresentam dificuldades próprias.

\subsubsection{Características das atividades de expressão oral}

Para Goméz, A. (2005, p. 222), existe uma gramática de uso oral, um conjunto de atos verbais e não verbais que vão além da descrição gramatical. $\mathrm{O}$ autor afirma que não se trata de estudar outra gramática para fazer uso da oralidade, mas de ter presente toda uma série de fenômenos verbais e não verbais próprios desse tipo de comunicação. O modo de comunicação oral, frente ao escrito, se caracteriza por uma série de traços, como:

a) imediatez no tempo e no espaço: a interação presencial contém uma grande quantidade de informação referencial ao falante e ao ouvinte. São observadas as reações de ambos, seus gestos, suas manifestações de acordo ou desacordo com o que foi emitido, além da possibilidade de pedido de esclarecimentos, ou seja, os interlocutores negociam cara a cara seus papéis e suas relações interpessoais.

b) forma de manifestação das relações sociais entre os interlocutores: a interação oral permite que as funções do falante e do ouvinte sejam diferentes das do autor e do leitor, já que estes iniciam e terão que manter as posições sociais iniciais. 
c) o tempo em que transcorre a mensagem e os limites de memória e de retenção da mensagem: o controle do que foi produzido e do que foi recebido é menor na produção oral, além disso, o discurso oral costuma aparecer com correções contínuas e autoexplicações.

d) a articulação do discurso: a expressão oral implica não somente a articulação sucessiva dos fonemas que constituem o significante dos signos linguísticos, mas também, simultaneamente, se acrescentam elementos como a entonação, as pausas, a nitidez da voz, os suspiros, as risadas, etc.

Portanto, o autor afirma que devido a esses fatores e parâmetros que diferenciam a comunicação através do canal fônico ou gráfico, a oralidade se diferencia linguisticamente da escrita não só nos aspectos articulatórios citados, mas na estrutura sintática, no modo de construir os enunciados, na maneira de proferir a mensagem, por conseguinte, na produção de sentidos.

Pinilla Gómez (2005) afirma que, na expressão oral, o objetivo do processo de aprendizagem é o uso da língua por parte dos estudantes, em atos de comunicação com um ou mais interlocutores, a fim de satisfazer suas necessidades comunicativas concretas nesses contextos. Por isso, a comunicação é um processo ativo, é ação que, para ser ensinada em sala de aula, necessita de atividades que reflitam, da melhor maneira possível, as situações que ocorrem fora do contexto educativo. Ou seja, as atividades devem se aproximar, ou simular, as situações reais de comunicação.

Ainda de acordo com a autora, a expressão oral se apresenta em duas fases: a) assimilação, que está relacionada à compreensão auditiva, com atenção voltada para os aspectos formais e menos ao conteúdo; e b) criação, que está relacionada à produção e que pode ser livre ou dirigida pelo professor. Nessa última fase a atenção está voltada mais para o conteúdo do que para os aspectos formais, dessa forma, há que se trabalhar com atividades diferentes, dependendo do nível e da fase em que se encontra o estudante.

Todas as atividades que se realizam com foco no desenvolvimento da expressão oral devem ater-se aos seguintes princípios: a) ser significativas; b) tratar de temas e realidades próximas ao aluno; c) serem abertas para que o aluno possa se expressar quanto a ela; d) ter um feedback; e) dosar a dificuldade gradativamente; e f) levar em conta o nível de aprendizagem do aluno (PINILLA GÓMEZ 2005).

No momento de se desenvolver uma atividade de expressão oral, o professor deve ter em mente a ampla variedade de atividades, observando cada momento do programa de ensino e cada 
objetivo. É necessário observar o nível de conhecimento do estudante, o grau de formalidade da língua falada e o canal comunicativo utilizado. As seguintes atividades podem ser propostas com vistas a desenvolver a expressão oral: a) diálogos ou conversações; b) entrevistas; c) dramatizações; d) exposições de temas; e) debates; f) conversações telefónicas e mensagens a serem gravadas; e g) atividades de caráter lúdico. (PINILLA GÓMEZ, idem)

A partir das informações apresentadas sobre a oralidade, nota-se que pesquisas sobre o tema têm sido frequentes, no sentido de contribuir para o processo de ensino-aprendizagem de línguas estrangeiras no mundo; no entanto, não foi sempre assim, a oralidade foi uma habilidade deixada de lado por algum tempo, mas passa a aparecer com mais força nas abordagens e métodos mais recentes (SANTOS 2013), tema que será exposto a seguir.

\subsubsection{Oralidade nas abordagens e métodos do século $\mathrm{XX}$}

Vilaça (2008, p.74) afirma que apesar de o século XIX ser considerado o início de importantes mudanças e inovações, onde se buscou encontrar o "método perfeito", "foi na segunda metade do século XX que a obsessão por métodos de ensino de línguas estrangeiras atingiu seu nível mais elevado". Essencial aqui identificar o conceito de método, dado pelo autor na página 75 :

A palavra método vem do grego méthodos, uma palavra composta por meta, que denota sucessão, ordenação e hodós, que significa via, caminho. Partindo desta etimologia, é possível afirmar que o conceito de método está relacionado a um caminho que, seguido de forma ordenada, visa a chegar a certos objetivos, fins, resultados, conceitos etc.

Na mesma linha do conceito de método dado por Vilaça (2008), há a definição de abordagem, método e técnica de Anthony (1963). De acordo com esse autor, as técnicas executam um método que é consistente com uma abordagem. Colocando os termos de forma mais clara, a abordagem é definida por ele como um conjunto de pressupostos correlacionados, tratando da natureza da língua e da natureza do ensino e do aprendizado de línguas; já o método é descrito como um plano global para a apresentação ordenada do material de linguagem, sendo que ele se baseia na abordagem selecionada; por fim, a técnica é algo que se implementa, ou seja, aquilo que de fato acontece na sala de aula. Almeida Filho (1997, p. 19) vai ao encontro dessas definições, afirmando que "Anthony e Almeida Filho mantêm a hierarquia descendente a partir 
da abordagem no topo, baixando para o método e finalmente para as técnicas ou procedimentos", conforme ilustração a seguir:

Figura 3 - Posição hierárquica

\section{Abordagem}

Método

Técnica

Entender a diferença entre esses termos é fundamental para um melhor entendimento das mudanças no processo de ensinar e aprender línguas. De acordo com Santos (2013, p.21), é possível dividir a cronologia de ensino de línguas estrangeiras em duas etapas: a primeira seria referente à abordagem tradicional dos anos 40, em que, inicialmente, teve ênfase na escrita, focando a gramática e a tradução, "pautando a aprendizagem pela memorização e pela absorção de vocabulário da língua-alvo". Posteriormente, as teorias se apresentam com ênfase no oral, norteando a aprendizagem "pela prática mecanicista focada na memorização e repetição das frases faladas". A segunda etapa, já nos anos 70, impulsionada pelo comunicativismo, é que se apresenta a aprendizagem da LE, escrita ou oral, valendo-se do contexto em que é produzida; portanto, "passou-se à necessidade de considerar o contexto da produção, o qual dava razão de ser não à escrita ou fala, mas, à expressão pela coerência do sentido que apresenta." (p. 22). Dessa forma, a autora destaca como sendo possível identificar a presença da oralidade na evolução histórica do ensino de línguas estrangeiras, seja por uma abordagem tradicional, seja pela abordagem comunicativa.

Essa informação é confirmada nos estudos de Mendes (2013), que considerou os seguintes métodos e abordagens para análise da oralidade: o Método Audiolingual, a Abordagem Comunicativa e o Sociointeracionismo. A autora faz a sua análise baseada em Diane LarsenFreeman (2000), em seu estudo intitulado Teachniques and Principles in Language Teaching, e 
Vilson Leffa (1988), em Metodologia do Ensino de Línguas. Com base nesses estudos, escolhi o método audiolingual e a abordagem comunicativa para fazer um pequeno contraponto quando se trata de abordagens e métodos que envolvem a oralidade. A escolha se deve por entender que essas duas teorias são as mais recentes aplicadas ao contexto atual de ensino de línguas, principalmente em termos de oralidade (ERES FERNÁNDEZ \& MACIEL 2007).

Método audiolingual: de acordo com Leffa (1988 p. 221), o método (ligado à abordagem gramatical) estabelecia a ênfase na língua oral. $\mathrm{O}$ entendimento era que "o que não fosse fala também não era língua. Daí que ensinar a leitura não era ensinar a língua". Por isso, o estudante só deveria ser exposto à língua escrita quando os padrões da língua oral já estivessem bem automatizados. No entanto, o processo de aprendizagem se dava por repetições incansáveis, que deixavam as aulas cansativas. Além disso, passou-se a questionar a primazia da fala, o que deu lugar a uma visão da língua em que a fala e a escrita fossem formas paralelas em termos de manifestação.

Abordagem comunicativa: nessa abordagem a língua era analisada não como um conjunto de frases, mas como um conjunto de eventos comunicativos (LEFFA, 1988). O que se defende é o uso de linguagem adequada à situação em que ocorre o ato da fala e ao papel desempenhado pelos participantes. Os diálogos artificiais, elaborados para apresentarem pontos gramaticais são rejeitados. A ênfase da aprendizagem está na comunicação, buscando o uso da língua em situações de interação real.

Mendes (2013) compara as duas teorias afirmando que a abordagem comunicativa, diferentemente do método audiolingual, enfatiza a semântica da língua, enquanto no método audiolingual o foco está na aprendizagem de LE pelo seu código. Além disso, também em contraste com o método audiolingual, na abordagem comunicativa é permitido o uso da LM dentro de sala de aula, principalmente nos primeiros contatos com a LE.

Diante disso, é possível observar a oralidade sendo atualmente trabalhada em abordagens diferentes (gramatical e comunicativa), apresentada e desenvolvida de formas distintas. No entanto, há que se ter uma atenção ao discurso de aplicação de abordagem comunicativa no ensino de línguas, pois, de acordo com Santos (2013), houve uma mudança de paradigma no que se refere à compreensão de língua ensinada e, atualmente, a maioria dos discursos afirma a aplicação da abordagem comunicativa em seu contexto de ensino, trabalhando, portanto, a 
oralidade, focando na comunicação. No entanto, na prática, o que se percebe é um ensino da língua ainda com ênfase em seu aspecto estrutural.

As teorias expostas servirão de base para as análises que serão apresentadas no capítulo 4. Antes disso, apresento a seguir o capítulo metodológico, em que serão apresentados a metodologia de pesquisa, os instrumentos para coleta de dados e a forma como ocorrerá a análise desses dados. 


\section{CAPÍTULO 3}

\section{METODOLOGIA DE PESQUISA}

"Este processo, designado de pesquisa, genericamente pode-se definir como um esforço durável de observações, reflexões, análises e sinteses para descobrir as forças e as possibilidades da natureza e da vida, e transformá-las em proveito da humanidade."

(CHIZZOTTI 2006, p. 19)

Neste capítulo apresento a metodologia utilizada para a realização da pesquisa, que se concentra na perspectiva da pesquisa qualitativa, mas que apresenta traços da pesquisa quantitativa, e utiliza a metodologia do estudo de caso. Adiante serão esclarecidas a escolha da natureza da pesquisa, a metodologia utilizada, além de contextualizar a pesquisa, o perfil dos participantes e os instrumentos a serem utilizados na coleta e na análise do dados.

\subsection{AS PESQUISAS QUALITATIVA, QUANTITATIVA E O ESTUDO DE CASO}

Chizzotti (2006) define pesquisa como um esforço durável de observações, reflexões, análises e sínteses para descobrir as forças e as possibilidades da natureza e da vida, e transformálas em proveito da humanidade. Partindo desse pressuposto, observa-se que não há uma única maneira de se realizar a pesquisa.

Apoiada em Denzin e Lincoln (2006) apresento a diferenciação entre a pesquisa quantitativa e a pesquisa qualitativa. De acordo com os autores, a palavra qualitativa implica uma ênfase sobre as qualidades das entidades e sobre os processos e os significados que não são examinados ou medidos experimentalmente em termos de quantidade, volume, intensidade ou frequência; enquanto que os estudos quantitativos enfatizam o ato de medir e de analisar as relações causais entre variáveis, e não processos.

Apesar dessa divisão entre pesquisa qualitativa e quantitativa, e as pesquisas em LA estarem concentradas na tipologia qualitativa, Lazaraton et. al (apud KURTZ 2004) afirmam que apesar de essa abordagem para coleta e análise de dados ser importante para as diferentes questões em LA, a realização de estudos direcionados a métodos quantitativos também é necessária, especialmente porque essas duas modalidades podem co-ocorrer em uma mesma investigação. Esta pesquisa, apesar de estar apoiada no tipo qualitativo, apresenta características 
da pesquisa quantitativa, como perguntas fechadas que gerarão gráficos, que serão relevantes para uma observação detalhada e analítica do caso.

A pesquisa qualitativa pode ocorrer por meio de diferentes métodos, entre eles estão a entrevista, observação participante, história de vida, testemunho, análise do discurso, estudo de caso etc. (CHIZZOTTI 2006). Este último método, estudo de caso, será o utilizado nesta pesquisa. De acordo com Faltis (1997), o estudo de caso passou a ser usado nas pesquisas da área de ciência social a partir dos anos 40, mas somente a partir dos anos 70 os pesquisadores das áreas de educação e linguagem adotaram esse método em suas pesquisas.

Em termos de definição, Moura Filho (2005 p. 106) define o estudo de caso como "uma investigação detalhada de um objeto ou fenômeno e de suas relações com o contexto no qual está inserido". Dessa forma, segundo o autor, essa investigação, no âmbito escolar, pode tanto envolver um sistema simples, como um único aluno, até algo mais complexo, como a mobilização da comunidade escolar, com vistas à melhoria de processos de ensino-aprendizagem. Com base na definição do autor, a presente pesquisa se apresenta como um estudo de caso em que serão investigados dois grupos diferentes de estudantes, a serem definidos mais adiante.

A utilização do método quantitativo associado ao qualitativo neste estudo está apoiada em Günther (2006), que afirma que abordagens qualitativas, que tendem a ser associadas a estudos de caso, dependem de estudos quantitativos, que visem a gerar resultados generalizáveis e parâmetros. Dessa forma, o autor propõem que se dilua a controvérsia entre o estudo de caso (que seria uma investigação aprofundada de uma instância de algum fenômeno), e o estudo envolvendo um número estatisticamente significativo de instâncias de um mesmo fenômeno, a partir do qual seria possível generalizar para outras instâncias. Além do mais, o entendimento aqui é que em um estudo de caso é possível utilizar tanto procedimentos qualitativos quanto quantitativos.

Stake (1994) indica que o pesquisador deve seguir os seguintes pontos na construção do estudo de caso: delimitação, conceituação do objeto de estudo; seleção do tema, elaboração das perguntas de pesquisa; padronização dos dados para gerar conclusões; triangulação das observações significativas e bases para interpretação; seleção de interpretações e desenvolvimento de asserções e possíveis generalizações sobre o caso. Transpondo esses pontos de construção para a presente pesquisa temos: a) delimitação: trata-se de uma pesquisa restrita a uma instituição de ensino pública; b) conceituação do objeto de estudo: trata-se da observação e análise da prática da oralidade dos estudantes de licenciatura de um curso a distância; c) perguntas de pesquisa: a 
modalidade a distância, na forma como está praticada na situação de pesquisa, atende de que forma à prática da oralidade no ensino de LE (espanhol)? Quais características predominam no curso EaD (espanhol) no que se refere ao trabalho com a oralidade do idioma? Como o trabalho com a oralidade é visto pelos alunos do curso? Quais práticas podem ser inseridas nesse tipo de curso visando melhorias no contexto da oralidade no ensino de LE por meio da EaD? Esses são pontos de construção já determinados, no próximo capítulo os demais serão desenvolvidos.

Ainda na linha de entendimento do estudo de caso, uma característica comum a todos os métodos de estudo de caso, desde o seu desenvolvimento como estratégia de pesquisa, é que eles examinam um fenômeno específico como um sistema limitado (SMITH 1978 apud FALTIS 1997). Ainda de acordo com Faltis (1997), existem dois tipos de métodos para o estudo de caso, o interpretativo e o interventivo. A principal diferença entre eles é que no método interventivo o pesquisador analisa o efeito da intervenção sobre os participantes, enquanto no método interpretativo não há intervenção. A presente pesquisa utiliza o estudo de caso de caráter interpretativista, que pretende analisar a prática da oralidade na plataforma virtual de ensino de LE (espanhol) e coletar dados suficientes para entender o processo e chegar a conclusões.

A escolha de um estudo de caso de caráter interpretativista ganha força ao contrastar com a afirmação de Moita Lopes (1994), que destaca que na pesquisa interpretativista não é possível ignorar a visão dos participantes do mundo social, já que é esta que o determina. Portanto, o mundo social é tomado como existindo na dependência do homem. Dessa forma, não se pode ignorar as opiniões dos estudantes na presente pesquisa, já que eles são a peça-chave no processo de formação de professores de LE no contexto da EaD.

André (1984, p. 52) afirma que "a metodologia do estudo de caso é eclética, incluindo, via de regra, observação, entrevistas, fotografias, gravações, documentos, anotações de campo e negociações com os participantes do estudo." Hamel (1993) também apresenta entendimento similar ao de André (1984). Para aquele autor, o estudo de caso pode empregar vários métodos, tais como observação, observação participante e entrevistas. André (1984) acrescenta que o estudo de caso, entre as suas características, procura representar os diferentes pontos de vista em uma situação social e complementa com a informação de que:

os estudos de caso procuram retratar a realidade de forma completa e profunda. Esse tipo de estudo pretende revelar a multiplicidade de dimensões presentes em uma dada situação, focalizando-a como um todo, mas sem deixar de enfatizar os 
detalhes, as circunstâncias específicas que favorecem uma maior apreensão desse todo. (p. 52)

A partir das definições propostas, este trabalho trata-se de uma pesquisa quali-quantitativa, estudo de caso, do tipo interpretativista, que lida com estudantes, e que, por ser um estudo de caso, pode utilizar vários métodos, mas que se restringirá à observação, questionários e entrevistas, a serem detalhados na sequência.

\subsection{A ESCOLHA Dos GRupos E os MÉtodos DE COLETA DE DAdOS}

A partir da proposta de pesquisa, conforme exposto anteriormente, escolhi uma instituição pública da cidade de Natal, no estado do Rio Grande do Norte, como instituição a ser pesquisada. O curso de licenciatura em língua espanhola na modalidade $\mathrm{EaD}$ é relativamente novo na instituição, tendo formado apenas uma turma no ano de 2014. O interessante em se trabalhar com um curso novo é que o seu plano de curso é recente, o que, muitas vezes, significa que contempla temas novos. O plano de curso pode, por exemplo, se organizar com base nas novas tecnologias, prevendo atividades interativas com vários recursos tecnológicos, além de poder se apoiar em abordagens e métodos para ensino de línguas estrangeiras recentes.

No momento da coleta de dados, primeiro semestre de 2015, o curso contava com três turmas em curso: segundo semestre, quarto semestre e sétimo semestre. $\mathrm{O}$ curso conta com nove semestres, e, em seu Plano Pedagógico de $\mathrm{Curso}^{23}$ (PPC) (2012, p.15 - destaques meus) afirma que o aluno licenciado deve ser capaz de:

1. Fazer uso das quatro habilidades linguísticas orais e escritas (compreensão, escrita, compreensão auditiva, expressão escrita e expressão oral) com proficiência, a fim de produzir discursos (escritos e orais em situações de comunicação diversas);

2. Analisar, selecionar e produzir materiais didáticos para o ensino da língua espanhola, levando em conta a importância dos aspectos culturais das sociedades que a falam.

\footnotetext{
${ }^{23} \mathrm{O}$ PPC, juntamente com outros materiais relevantes para esse trabalho de pesquisa estão disponíveis para consulta em uma pasta virtual que pode ser acessada pelo link:

https://www.dropbox.com/sh/jt78w4ora69c8xn/AAAfSWtPenwiI0SxtuzZ8Gbra?dl=0
} 
3. Reconhecer as variantes dialetais do espanhol para selecionar um modelo como referência geral da língua, que oriente seu ensino e que a aproxime dos interesses e necessidades reais dos aprendizes;

4. Utilizar as metodologias de ensino-aprendizagem direcionadas para as línguas estrangeiras e, sobretudo, especificamente para o ensino de língua espanhola, que lhe permitam optar a metodologia que considere mais adequada no marco da situação docente-discente em que se encontre;

5. Pautar-se nos valores da educação multicultural que possibilitem a comunicação internacional e o respeito entre as diferentes culturas;

6. Ter visão do seu papel social de educador com capacidade de interpretar e discernir sobre diversos temas e realidades quando em contato com seus educandos;

7. Ter a compreensão plena de como o processo de ensino-aprendizagem da língua espanhola afeta na formação do indivíduo;

8. Ter a visão de que o ensino e a aprendizagem da língua espanhola é acessível a todos, independente do contexto social, econômico ou histórico em que o educando se encontra;

9. Ter a visão global, sabendo-se posicionar como educador, em situações das mais diversas nos campos político, econômico e social;

10. Possuir uma sólida formação em conteúdos específicos da língua espanhola e ter consciência de como esta língua vem sendo construída; suas origens, processos de criação e inserção em outras áreas de conhecimento;

11. Criar, planejar, realizar, gerir e avaliar situações eficazes para a aprendizagem e para o desenvolvimento dos estudantes, utilizando conhecimento das áreas afins;

12. Ser capaz de trabalhar em equipes multidisciplinares e interdisciplinares de forma integrada com os professores da sua área e de áreas afins, no sentido de favorecer uma aprendizagem integrada e significativa para os seus alunos;

13. Adotar estratégias de aprendizagem continuada, de aquisição e utilização de novas ideias e tecnologias, reconhecendo a sua prática profissional também como fonte de produção de conhecimento;

14. Estabelecer e trabalhar relações entre a língua espanhola e outras áreas do conhecimento; 
15. Desenvolver estratégias de ensino que favoreçam a criatividade, a autonomia e a flexibilidade do pensamento linguístico dos estudantes, buscando trabalhar com ênfase nos usos da língua viva e multicultural.

A partir do que se espera do licenciado, com base no destacado no PPC, o que destaco nesse primeiro momento é o tópico 1 (fazer uso das quatro habilidades linguísticas orais e escritas com proficiência), mais especificamente à condição de fazer uso da habilidade linguística oral, apesar de, conforme exposto anteriormente, as habilidades estarem interligadas durante a aprendizagem e grande parte dos pontos em destaque serem levados em consideração no momento das análises dos dados.

Em termos de meios para que o licenciado atinja o esperado no tópico 1, durante todo o curso frequenta disciplinas específicas da língua espanhola, espalhadas entre os nove semestres: Língua espanhola I, II, III, IV, V e VI; Fonética e fonologia do espanhol I e II; Linguística I e II; Morfossintaxe I e II; História da língua espanhola; Teoria da literatura I e II; Dialetologia do espanhol; Cultura hispânica; Literatura espanhola I e II; Literatura hispano-americana I e II; e Teoria e prática da tradução. Outras disciplinas podem influenciar no processo de desenvolvimento da habilidade oral, mas as citadas acima têm relação direta com a aprendizagem da LE em foco.

Para a análise em questão, que trata da oralidade, as disciplinas de língua espanhola e dialetologia são as escolhidas para se trabalhar. Escolhi as referidas disciplinas por serem as diretamente relacionadas com a aprendizagem da língua espanhola e que estavam em curso durante o primeiro semestre de 2015. De acordo com o PPC, essas disciplinas se concentram no núcleo específico, que se apresenta como o "relativo a disciplinas que fundamentam a formação do professor da educação básica na sua área de atuação específica. Compreende os saberes disciplinares ou conhecimentos científicos e tecnológicos que norteiam a formação do professor da educação básica na sua área de atuação específica" (p. 17).

Após documento solicitando acesso à plataforma do curso (Apêndice I), obtive a liberação da coordenação do curso para acesso ao ambiente virtual, nas disciplinas de língua espanhola II, língua espanhola IV e dialetologia. Cada uma dessas disciplinas são cursadas por diferentes alunos, em distintos módulos, correspondendo a: língua espanhola II ( $2^{\circ}$ semestre); língua espanhola IV ( $4^{\circ}$ semestre) e dialetologia ( $7^{\circ}$ semestre). Dessa forma, tenho acesso a 
estudantes iniciantes, intermediários e em processo de conclusão do curso. Apesar de os alunos do $4^{\circ}$ semestre não serem objeto direto da presente pesquisa, o acesso à disciplina língua espanhola IV foi importante para acompanhar o processo de construção de aprendizagem da língua espanhola. ${ }^{24}$

Esta diversidade de público é importante para a realização da triangulação de dados, percebendo o contraste entre os grupos e o seu desenvolvimento da oralidade em língua espanhola. A seguir exponho os instrumentos utilizados para a coleta de dados.

\subsubsection{A Observação}

A observação está relacionada à análise de quais atividades são propostas para os diferentes grupos na tentativa de desenvolver a oralidade desses estudantes. A partir dessa observação será possível contrastar os dados da turma iniciante com os dados da turma concluinte.

De acordo com Adler \& Adler (1994), a observação consiste na coleta de impressões de faculdades relevantes do mundo em volta. Uma das marcas da pesquisa é o não intervencionismo do pesquisador, portanto, este não deve manipular ou estimular os sujeitos que estão sendo observados.

Segundo os autores, o observador não-intervencionista:

1. não manipula nem estimula os sujeitos de sua observação;

2. não os faz perguntas de pesquisa;

3. não lhes propõe tarefas;

4. não cria novas provocações deliberadamente;

5. segue a sequência de eventos;

6. o comportamento e a interação [por parte dos sujeitos estudados] se dão como se o observador não lhes estivesse assistindo.

\footnotetext{
${ }^{24} \mathrm{O}$ foco da pesquisa é contrastar os dados dos iniciantes e dos concluintes do curso, por isso os intermediários não foram pesquisados. A navegação na disciplina ofertada para os intermediários buscou coletar mais informações sobre a apresentação do curso e suas atividades de prática oral. Ou seja, por se tratar de um estudo de caso no ambiente virtual, quanto mais possibilidades de rastreamento e informações houver, para conhecimento da plataforma, mais análises precisas poderão ser geradas.
} 
Como dito anteriormente, a presente pesquisa não possui caráter intervencionista, desta forma, espera-se que os sujeitos sejam observados em suas atividades habituais no ambiente virtual, sem que a minha presença, enquanto pesquisadora, altere o comportamento dos observados.

Meu acesso às disciplinas, que são organizadas e apresentadas em plataforma Moodle, contempla todos os alunos do semestre, independente do polo a que estão vinculados; no entanto, há divisão de grupos por polo, e os estudantes apenas visualizam os seus colegas de polo. Apesar de ter acesso a todos os alunos do semestre, busquei focar nos alunos do Polo Natal, já que ele foi o polo escolhido para realização dos questionários e entrevistas.

No primeiro semestre de 2015 tive acesso às disciplinas, e, semanalmente acompanhei as atividades propostas, podendo acessar fóruns, chats e também as tarefas postadas pelos estudantes com os respectivos feedbacks. Nesse sentido, as coletas se davam de forma assíncrona, em que eu acessava o ambiente virtual e extraía de lá informações ou produtos das interações para trabalhar as análises. Durante as observações semanais fiz anotações (registro de notas de campo) em que apontava as impressões e possíveis informações que seriam relevantes no momento da análise de dados. Ressalto que apenas nos momentos de aplicação do questionário e da entrevista é que apareço para os estudantes enquanto pesquisadora.

\subsubsection{O Questionário}

Gil (1999) define questionário como a técnica de investigação composta por questões que são submetidas a pessoas com a intenção de obter informações sobre conhecimentos, crenças, sentimentos, valores, interesses, expectativas, aspirações, temores, comportamento presente ou passado etc. Optei por inserir também os questionários (anônimos) como forma de maior obtenção de dados, já que a entrevista, apesar de ser aberta a todos, costuma ter uma menor adesão dos estudantes. O questionário (Apêndice II) contou com questões um pouco diferenciadas para cada grupo, ou seja, questões ligadas à expectativa para os iniciantes; e impressões sobre o processo para os formandos. As questões se categorizaram nos tipos abertas e fechadas, mas se apresentaram de forma curta e direta, já que questionários longos desestimulam os respondentes. Foi a partir dos dados das perguntas objetivas que constam no questionário que foram construídos gráficos, essenciais para discutir o perfil do estudante no caso em análise. 
Com os avanços tecnológicos, o questionário não precisa ser aplicado por correio, bastando disponibilizá-lo em meio eletrônico, o que facilita o acesso e desperta interesse do respondente. No entanto, apesar de a ideia inicial ser a aplicação de questionários virtuais, os questionários foram aplicados in loco, no formato impresso, no dia em que os estudantes se reuniram para a realização da prova presencial da disciplina que estavam cursando. Essa decisão foi tomada visando ter uma maior participação de estudantes nessa etapa da pesquisa.

As aplicações dos questionários foram realizadas nos dias 28/03/2015 (para os estudantes do segundo semestre) e no dia 13/06/2015 (para os estudantes do sétimo semestre). Nas mesmas datas foram realizadas as entrevistas com os estudantes.

\subsubsection{A Entrevista}

De acordo com Rosa \& Arnoldi (2006), a entrevista pode ser classificada, com relação a sua estruturação e roteiro, em estruturada, semiestruturada e livre. As questões estruturadas possuem um roteiro com questões formalmente elaboradas, que seguem uma sequência padronizada e são voltadas para a obtenção de respostas curtas e concisas. Desta forma, segundo as autoras, normalmente os dados colhidos por meio de um roteiro estruturado serão submetidos a uma análise quantitativa.

Oposta à entrevista estruturada há a entrevista livre. Para Fernandes (1991 apud ROSA \& ARNOLDI 2006), as entrevistas livres são feitas através de um relato oral que coleta informações em que o interlocutor desenvolve suas ideias quase sem interferência do entrevistador. No entanto, alguns autores afirmam que a análise deste tipo de dado é subjetiva, portanto, de acordo com as autoras supracitadas, a escolha do tipo de estruturação do roteiro pode levar às entrevistas valores de objetividade ou subjetividade.

Com base nas informações acima, e analisando o caráter da presente pesquisa, optei por utilizar o tipo de entrevista que aparece entre a estruturada e a aberta, no caso, a entrevista semiestruturada. Ainda com base em Rosa \& Arnoldi (2006), as questões que fazem parte da entrevista semiestruturada deverão ser formuladas de forma em que o sujeito entrevistado discorra e verbalize seus pensamentos, tendências e reflexões sobre os temas apresentados. $\mathrm{Na}$ entrevista semiestruturada é possível fazer uma avaliação de crenças, sentimentos, valores, atitudes, razões e motivos acompanhados de fatos e comportamentos. 
Dessa forma, a partir do roteiro de entrevista semiestruturada (Apêndice III), todos os estudantes presentes no dia da aula presencial no polo foram convidados a participar da pesquisa. A estimativa era entrevistar de três a cinco estudantes de cada nível/turma; ou seja, estudantes do segundo semestre e estudantes do sétimo semestre. No entanto, a aceitação foi muito positiva nos estudantes do segundo semestre; dessa forma foram entrevistados sete estudantes do segundo semestre e três estudantes do sétimo. As perguntas foram baseadas na estrutura do curso, nas atividades realizadas dentro da plataforma virtual de aprendizagem e nas percepções desses futuros profissionais em relação ao domínio da oralidade.

Apesar de tratar-se de uma instituição fora do Distrito Federal, as entrevistas foram presenciais, com a minha ida ao Polo Natal, onde os estudantes realizam as provas presenciais. Como já exposto, foram realizadas duas visitas aos polos e a decisão de realizar a entrevista pessoalmente se deve ao fato de conseguir uma maior participação dos estudantes. Foi necessário considerar que, apesar de realizar um curso na modalidade EaD, alguns estudantes ainda possuem dificuldades com a tecnologia, principalmente para a realização de um entrevista virtual. Além disso, problemas de conectividade poderiam atrapalhar a atividade de entrevista.

As entrevistas, em sua totalidade, encontram-se no Apêndice IV desta dissertação, no entanto, para o corpo do texto, serão trazidos os recortes mais significativos que serão discutidos. Todas as perguntas da entrevista visaram a entender o processo da prática da oralidade no ambiente virtual e as percepções dos estudantes com relação a esse processo. Destaco que os nomes que aparecem para os entrevistados não são verdadeiros, eles foram trocados para preservar a identidade dos respondentes.

Utilizando então os instrumentos para coleta de dados (observação, questionário e entrevista), obtive dados para análise e a elaboração deste trabalho. A forma como foram pensadas as análises e escrita do trabalho serão detalhadas a seguir.

\subsection{PROCEDIMENTOS DE ANÁLISE DE DADOS}

A análise de dados do estudo de caso se dará com base nas teorias de André (2013). Vale ressaltar o que a autora diz sobre o processo de análise: "a análise no estudo de caso está presente nas várias fases da pesquisa, tornando-se mais sistemática e mais formal após o encerramento da coleta de dados" (p. 101). Em termos práticos, o que a autora sugere são passos, descritos a seguir: a) o primeiro passo é organizar todo material coletado; no caso desta pesquisa serão 
fontes de análise as anotações advindas da observação de atividades e interação na plataforma virtual de aprendizagem, os dados dos questionários e as entrevistas realizadas com os estudantes; b) passo seguinte, após a organização do material é a leitura e releitura dessa documentação, identificando pontos relevantes para se iniciar o processo de construção das categorias analíticas. Por fim, esse trabalho deverá resultar num conjunto inicial de categorias que serão reexaminadas e reorganizadas num momento subsequente, em que aspectos comuns serão reunidos, pontos de destaque separados e realizadas novas combinações ou desmembramentos.

Dessa forma, durante as coletas de dados, alguns temas se apresentaram de forma recorrente e relevante para se pensar na formação de professores de LE na modalidade EaD. Com base nesses temas, comecei a traçar as categorias, tanto para apresentação do que seria real no caso em análise quanto o que seria necessário com base nas percepções dos estudantes. Essas categorias foram construídas nessa taxonomia tendo em vista também a observação em campo e os vestígios detectados, com base nos objetivos de observar a realidade e esmiuçar características de necessidade a partir dos relatos e do olhar observador.

Ainda citando André (2013), é importante destacar que tendo em vista que a categorização por si só não esgota a análise, é necessário recorrer aos fundamentos teóricos e às pesquisas sobre o tema para estabelecer conexões e relações que permitam apontar as descobertas ou achados do estudo, já que, afinal, de acordo com Stake (1994), o mais importante para o estudo de caso não é apenas o fazer metodológico, o fundamental é o conhecimento do caso ou o que se aprende ao estudá-lo, chegando a conclusões.

Por fim, com relação ao processo de escritura de um resultado de pesquisa, Matos (1985 apud MOREIRA \& CALEFFE 2006) afirma que redigir é um processo de pensar, refletir, explorar opções, tomar decisões, aprimorar a produção textual, visando acima de tudo à inteligibilidade da mensagem. Desta forma, espera-se que o estudo de caso seja conciso e que, de acordo com André (2013), se preocupe com a transmissão direta, clara e bem articulada do caso, num estilo que se aproxime da experiência pessoal do leitor. Como resultado, o estudo trará reflexões concernentes à formação docente no contexto da EaD. Sigo então para o próximo capítulo, a análise dos dados. 


\section{CAPÍTULO 4}

\section{ANÁLISE DOS DADOS}

"No puede decirse que haya una tecnología más apropiada para el estudio del lenguaje, sino más bien un abanico de herramientas tecnológicas de las que se puede disponer para ese fin, aunque las herramientas como tales sigan cambiando muy deprisa.",25

Como o foco desta pesquisa é rastrear a realidade e a necessidade no contexto de trabalho com a oralidade na EaD, neste capítulo serão expostos os dados coletados durante a pesquisa, que envolvem observações no ambiente virtual e percepções dos estudantes, coletadas nos questionários e nas entrevistas realizadas. Esse material analisado, que considero o bloco relacionado à realidade, será exposto na forma de temas, em que aparecem as minhas reflexões; na sequência apresento as sugestões de atividades para a prática da oralidade propostas pelos estudantes que participaram da pesquisa, sendo que essa última parte representaria a necessidade.

\subsection{ANALISANDO A REALIDADE}

A partir das informações coletadas, foi possível levantar temas relevantes à formação de professores de LE no contexto da EaD sob a perspectiva da oralidade e dos fatores que envolvem o tema. As análises sobre a realidade desse processo são apresentadas a seguir.

\subsubsection{O que os estudantes buscam no curso}

Entender o público participante do curso em análise, e, consequentemente da presente pesquisa, é fator primordial para tecer com maior precisão as análises. Nesse sentido, situar esses estudantes no contexto da aprendizagem em EaD se faz necessário, pois, apesar de a EaD estar em plena expansão e com as grandes possibilidades de aprender línguas por meio da Web,

\footnotetext{
25 "Não se pode dizer que haja uma tecnologia mais apropriada para o estudo da linguagem, mas, sim, que há um leque de ferramentas tecnológicas das que se pode dispor para esse fim, ainda que as ferramentas sigam mudando muito depressa." (MARÍN 2005, p. 29)
} 
conforme citado anteriormente (PAIVA 2013; GARCÍA M. 2005; MARÍN 2005), nem todos têm acesso ou fazem uso dela. Esse fato se confirmou já nos primeiros dados da pesquisa, quando os estudantes participantes, quando questionados acerca de já terem cursado outro curso de $\mathrm{LE}$ na modalidade $\mathrm{EaD}$, responderam quase que totalmente que não haviam realizado nenhum curso de línguas usando essa modalidade de ensino. Apenas uma estudante afirmou ter realizado um curso de inglês na modalidade $\mathrm{EaD}$, mas não deixou relatos dessa experiência.

Esses dados foram obtidos por meio dos questionários aplicados, mas outras informações obtivas por meio das observações no ambiente virtual e das entrevistas me induziram a levantar a hipótese de que essa não realização de cursos de línguas pela EaD está relacionada à dificuldade de lidar com a ferramenta tecnológica, ou com a metodologia de um curso a distância, que alguns estudantes apresentam. A estudante Marta do segundo semestre afirma que:

$[1]^{26}$ a modalidade à distância é complicada, eu já fiz outro curso à distância e é complicado porque, primeiro você não está ali o tempo todo, não tem como pedir ajuda o tempo todo, e a questão da fala mesmo, é bem complicado, ainda mais de língua; um [curso] normal já é complicado.

A questão levantada pela estudante Marta aparece durante as observações no ambiente virtual, especialmente na disciplina ofertada aos estudantes do segundo semestre. Durante as observações foi possível notar que era frequente ver que muitas das perguntas dos estudantes, postadas no fórum de dúvidas, não foram respondidas pelos tutores ou professores, mesmo que algumas não estivessem nos fóruns corretos. Esse fato aumenta a sensação descrita pela estudante de não ter alguém para ajudar os estudantes no processo.

A dificuldade com a ferramenta tecnológica aparece em meus registros pessoais de navegação no ambiente virtual do curso, especificamente na disciplina de Língua Espanhola II, oferecida aos estudantes do segundo semestre. Observei nas primeiras semanas de acesso uma dificuldade dos estudantes em manusear a ferramenta tecnológica, surgindo questionamentos aos tutores sobre como gravar o áudio para ser postado no ambiente virtual.

Essa dificuldade dos estudantes chamou a atenção por haver uma instrução detalhada de como enviar o material, mas, ainda assim, os estudantes tiveram dificuldades. A figura 4, a seguir, ilustra parte do tutorial disponibilizado. A minha percepção é que o tutorial não se

${ }^{26}$ Os excertos extraídos das entrevistas e questionários foram adaptados à norma culta da língua portuguesa. 
apresenta de forma a deixar o procedimento simples, mas não posso deixar de observar que se apresenta como uma possibilidade para os estudantes que têm dificuldades com esse tipo de ferramenta.

\section{Figura 4 - Instruções para gravação de áudio}

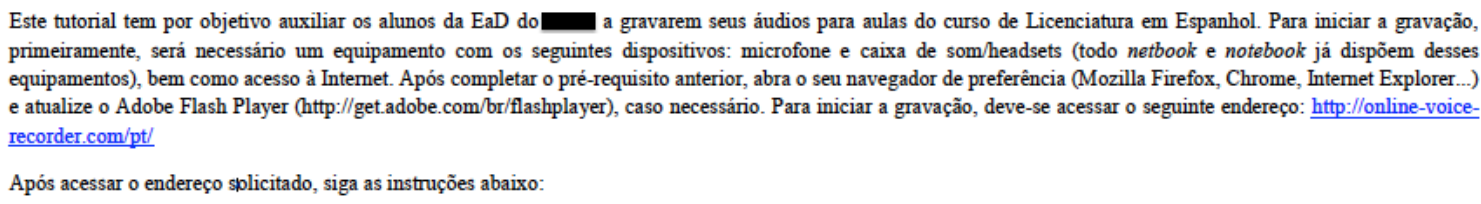

Figura 1

Ao acessar o endereço solicitado, e caso seja seu primeiro acesso à página, aparecerá uma mensagem de configuração do Adobe Flash Player (ver Figura l).

Pertinente destacar que essa dificuldade estava concentrada na disciplina para alunos do segundo semestre. O entendimento é que com o desenrolar do curso os estudantes aprendem a lidar com os recursos tecnológicos disponíveis no ambiente virtual, já que esse tipo de problema não aparece na disciplina para estudantes do sétimo semestre.

As informações acima começam a explorar a relação dos participantes da pesquisa com os cursos de LE na modalidade EaD. Essa análise inicial mostrou que os estudantes não haviam realizado outro curso de LE nessa modalidade, além de muitos apresentarem dificuldades em lidar com a tecnologia, então surge o questionamento relativo à motivação para a realização do curso em análise. 


\section{A motivação para realização do curso}

De forma geral, independente do semestre ao qual os participantes estavam vinculados, as respostas obtidas pelos questionários sobre a motivação para realizar o curso giraram em torno de construções como "aprender uma outra língua" ou "o interesse pela língua espanhola, conhecer melhor."

Tanto nas respostas dos estudantes do segundo quanto nas do sétimo semestre é visível uma motivação relacionada ao gostar da língua ou ter interesse em aprendê-la. Além de estarmos lidando com grande parte de estudantes que não escolheram o curso por conta da docência, temos também um cenário em que as pessoas procuram um curso de licenciatura apenas para aprender uma nova língua, chegando, em geral, sem nenhum conhecimento dessa língua de que serão professores. Esse fato é muito comum em todas as universidades brasileiras, independente da modalidade de ensino, como apontado por Ferreira (2012) e Barcelos (1995) em seus estudos sobre crenças de aprender língua na universidade. $O$ fato é que as universidade brasileiras não realizam nenhum exame de proficiência da LE que será estudada no curso de licenciatura durante os processos seletivos para a entrada na universidade, o que significa que, em termos de LE, o público é bastante heterogêneo, e, como de fato já apontado nas respostas dos estudantes para a escolha do curso, grande parte deles busca aprender a língua depois que entra na universidade, como se pode observar por meio de uma resposta de questionário:

[2] Espero poder aprender a escrever bem e a ler bem, e sobre a fala, talvez precise fazer um curso por fora.

O estudante acima (do segundo semestre), quando questionado sobre as expectativas sobre a aprendizagem da língua espanhola até o final do curso, aponta o fato de escrever e ler bem, portanto demonstrando não ter domínio de nenhuma dessas habilidades na língua. A informação do não conhecimento da língua espanhola por parte dos estudantes se confirma quando eles foram questionados, por meio de perguntas fechadas dos questionários, sobre o conhecimento prévio de LE. A maioria dos estudantes do segundo semestre que participaram do questionário afirma que entrou com pouco ou nenhum conhecimento da língua espanhola. Já com os estudantes do sétimo semestre, a pesquisa revelou um público totalmente heterogêneo, tendo a mesma quantidade de estudantes em cada uma das opções. Estes dados são melhores observados nos gráficos a seguir: 


\section{Gráfico 1 - Conhecimento prévio da língua espanhola em alunos do $2^{\circ}$ semestre}

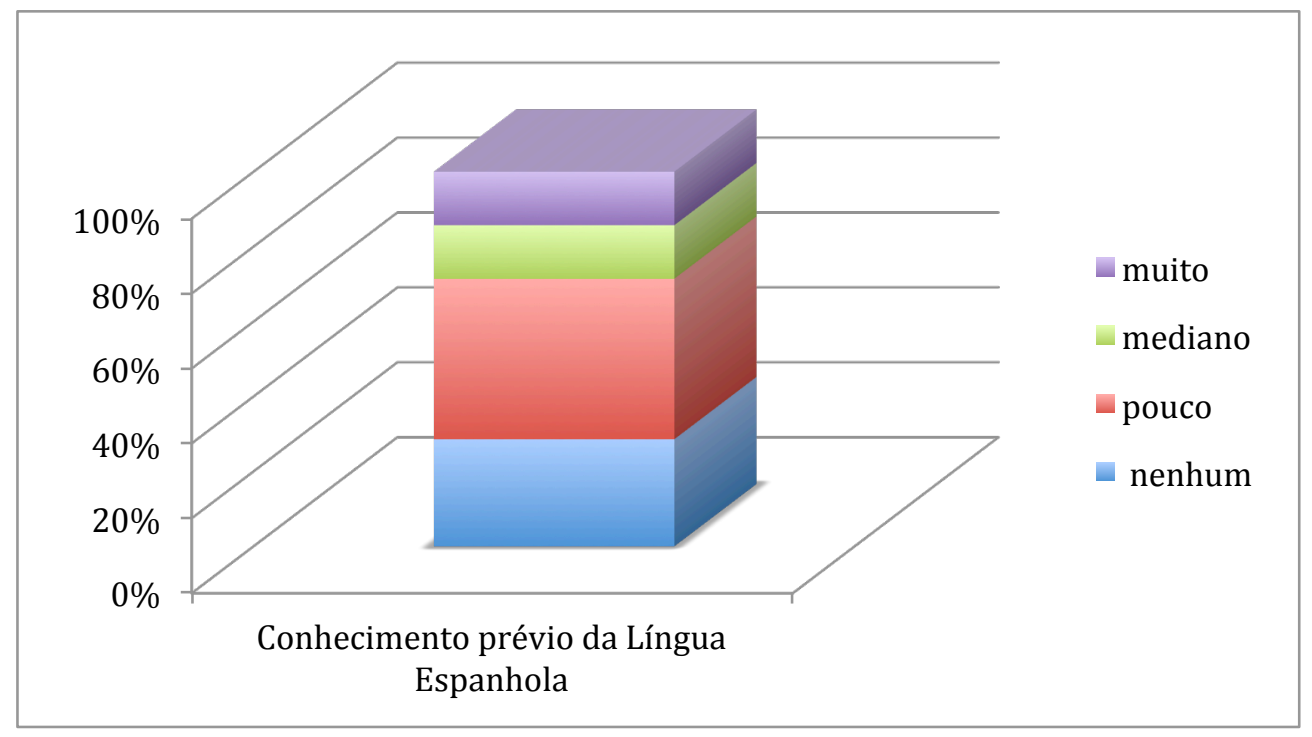

Gráfico 2 - Conhecimento prévio da língua espanhola em alunos do $7^{\circ}$ semestre

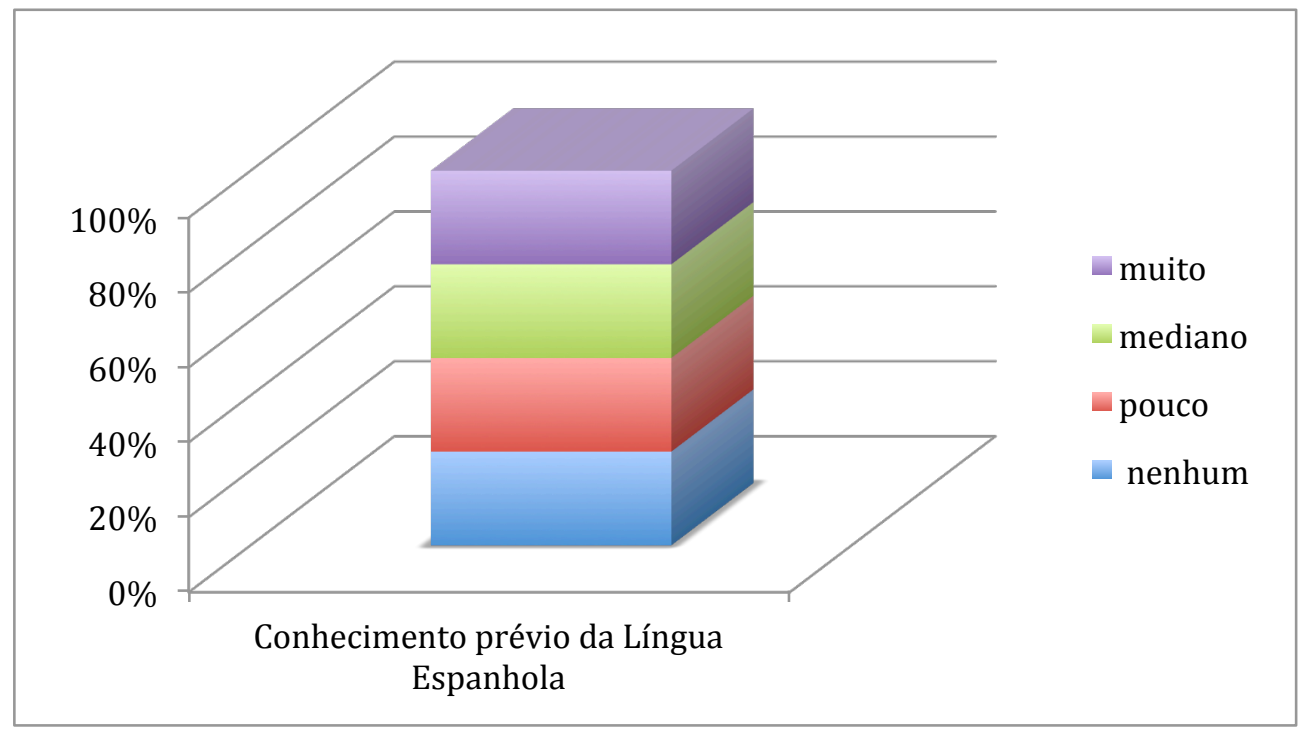

Os gráficos confirmam, portanto, a heterogeneidade, em termos de conhecimento prévio de língua, do público que se matricula no curso de LE. No entanto, quando se trata de oralidade, as respostas dos estudantes indicam sempre um pouco conhecimento e pouca liberdade para usar a língua de forma oral. De todos os estudantes entrevistados, apenas um afirma conseguir utilizar 
bem a língua espanhola de forma oral, e esse mesmo estudante afirma já ter entrado no curso com conhecimento prévio da língua. O tema conhecimento atual e oralidade serão trabalhados com mais afinco em outros tópicos que se seguem.

Voltando ao tema da motivação, ou o que leva o estudante a escolher um curso de LE, um estudante afirma que escolheu o curso pela baixa concorrência, o que gera preocupação, já que esse tipo de motivação inicial leva à evasão nos cursos. A surpresa é que já se trata de um estudante de sétimo semestre, que deve ter encontrado outras motivações durante o curso para permanecer nele. Em contrapartida, em entrevista o estudante demonstra o seu descontentamento com a EaD, afirmando que "sinceramente, eu não recomento EaD”. No entanto, durante a entrevista ele releva traços de atividades no curso que podem ter influenciado a sua permanência:

[3] a gente não tem aulas presenciais, nem se quer uma por mês, que seria ideal, nos ajudaria. Então tem poucas atividades que trabalham a oralidade; mas eu trabalho no PIBID ${ }^{27}$. O PIBID a gente vai pra sala de aula mesmo, a gente vai dar aula para os alunos. Embora o nosso subprojeto não seja bem do espanhol, a gente trabalha com gêneros textuais, mas nós envolvemos o espanhol. A gente trabalha textos da língua espanhola, textos hispano-americanos." (João $-7^{\circ}$ semestre)

Com base no que foi dito pelo estudante, o projeto PIBID do qual ele faz parte parece ter forte influência em sua prática e aprendizagem da língua espanhola, o que pode se caracterizar como um motivador para a sua permanência no curso.

A motivação se apresenta como um fator essencial no processo de aprendizagem de uma língua (BERGILLOS 2005), se a motivação não estiver presente no processo de aprendizagem de LE, esse tem grandes chances de não ser concluído.

\subsubsection{A questão do plágio no ambiente virtual}

Para adentrar a questão do plágio, tema que surgiu durante a análise de dados, começo com a afirmação de que há uma relação entre o plágio e a motivação, tendo em vista que uma ausência de motivação afeta o interesse do estudante e como consequência ele deixa de realizar com prazer os seus trabalhos escolares (MICHELON 2003).

O plágio no contexto da $\mathrm{EaD}$ não é assunto novo, mas que tem sido combatido com maior intensidade nos tempos atuais. De acordo com Dias \& Bastos (2014), o fenômeno do

\footnotetext{
${ }^{27}$ O PIBID é um projeto de extensão presencial, mas que não conta com a participação de todos os estudantes.
} 
plágio parece também estar fortemente associado ao uso das tecnologias e o fácil acesso à informação, com o agravante do contexto de pouco controle, e que ainda tem consequências leves no caso de ser detectado. Essa teoria se concretiza durante as observações no ambiente virtual. Notei que a disciplina de Língua Espanhola II apresentava atividades em que os alunos recorriam a pesquisas na Internet, porém, foi necessário que a coordenação do curso alertasse o estudantes sobre os perigos do plágio, tanto em termos de aprendizagem quanto a questões legais, conforme imagem a seguir:

\title{
Figura 5 - Advertência sobre plágio ${ }^{28}$
}

\begin{abstract}
Estimados alumnos, en la actividad evaluativa de la Semana 2, nosotros percibimos que muchos de ustedes no realizaron lo que se les proponía el material, que era la producción de un texto descriptivo sobre uno de los cuadros. En cambio, encontramos MUCHOS textos que fueron simplemente copiados de sitios bastante conocidos de la internet, que recibieron una nota bajísima, por supuesto.
\end{abstract}

Cuando uno copia y pega un texto que ya se encuentra listo en algún lugar, también está estudiando, ya que por lo menos lee las informaciones para seleccionar las que más le
interesen. Sin embargo, todos ya sabemos que el plagio es una acción condenable, que resulta en apropiarse de las palabras del otro, sin al menos pedirle permiso para hacerlo.

El aprendizaje que tanto buscamos en nuestro curso se construye efectivamente cuando nos disponemos a realizar las tareas propuestas para verificar hasta qué punto estamos aprendiendo, en qué aspecto hace falta buscar perfeccionamiento, y cuáles son las debilidades y fortalezas del proceso de enseñanza-aprendizaje que estamos realizando.

De esta forma, intentar burlar las orientaciones no es la mejor opción. Les animamos a estudiar e intentar realizar las actividades de manera autónoma, comprendiendo que el error forma parte del proceso de aprendizaje y que copiar las palabras de otras personas no les ayudará a construir su conocimiento de la lengua española. Piensen que, como futuros profesores que ustedes serán, esta conducta no está de acuerdo con la que esperamos que nuestros alumnos tengan. Esperamos que en esta próxima actividad evaluativa todos consigan poner práctica los conocimientos adquiridos hasta aquí y se dediquen a utilizarlos para su propio beneficio.

iEstamos a su disposición para ayudarles siempre que necesario!

Atentamente

28 "Queridos alunos, na atividade avaliativa da Semana 2, nós percebemos que muitos de vocês não realizaram o que o material propunha, que era a produção de um texto descritivo sobre um dos quadros. Pelo contrário, encontramos MUITOS textos que foram simplesmente copiados de sites bastante conhecidos da internet, que, claro, receberam uma nota baixíssima.

Quando uma pessoa copia e cola um texto que já se encontra pronto em algum lugar, também está estudando, já que pelo menos lê as informações para selecionar as que mais lhe interessam. No entanto, todos já sabemos que o plágio é uma ação condenável, que resulta em apropriar-se das palavras de outro, sem ao menos pedir-lhe permissão para fazê-lo.

A aprendizagem que tanto buscamos em nosso curso se constrói efetivamente quando nos dispomos a realizar as tarefas propostas para verificar até que ponto estamos aprendendo, em qual aspecto é necessário melhorar, e quais são as fraquezas e fortalezas do processo de ensino-aprendizagem que estamos realizando.

Dessa forma, tentar burlar as orientações não é a melhor opção. Motivamos vocês a estudar e tentar realizar as atividades de maneira autônoma, compreendendo que o erro faz parte do processo de aprendizagem e que copiar palavras de outras pessoas não lhes ajudará a construir seu conhecimento da língua espanhola. Pensem que, como futuros professores que vocês serão, esta conduta não está de acordo com a que esperamos que nossos alunos tenham. Esperamos que na próxima atividade avaliativa todos consigam por em prática os conhecimentos adquiridos até aqui e se dediquem a utilizá-los para seu próprio benefício.

Estamos à disposição para ajuda-los sempre que necessário.

Atenciosamente." 
$\mathrm{Na}$ disciplina de Língua Espanhola IV, o problema com o plágio também foi detectado pelos tutores e professores do curso. A seguir o comentário enviado a uma estudante depois da realização de uma atividade que deveria ser individual.

\title{
Figura 6 - Plágio nas atividades ${ }^{29}$
}

Nota: 5,0

\begin{abstract}
enmorar no tuviste tiempo de realizar la actividad de escucha? ¿Qué sucedió que tus

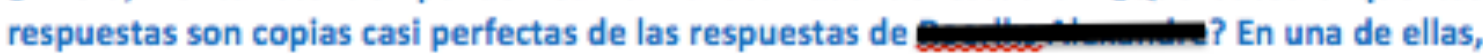
la del ítem "b)", no cambiaste absolutamente nada. Teniendo en cuenta eso no te puedo evaluar atribuyendo como nota máxima el 10,0, ya que esta actividad, que es individual, no fue realizada como se debería. Esté atenta para no cometer el mismo fallo en las próximas actividades. Busca hacerlas por ti misma y con antelación, solo así podrás desarrollar tu español aprendiendo con tus propios equívocos. Si se repito "copia" de respuestas entre alumnos en las próximas actividades INFELZMENTE la nota será 0,0 para los dos.
\end{abstract}

Assim como afirmou Dias \& Bastos (2014), a punição ainda é branda para esse tipo de prática. Exemplo disso é o fato de a estudante da imagem acima, mesmo tendo copiado o trabalho do colega de turma, receber nota 5,0. Ainda vivemos em um contexto de pouca punição e despertar de consciência para essa prática.

Essas situações expostas acima dialogam diretamente com as afirmações já apresentadas por Silva (2008) e Marín (2005), ao alertar que quando trabalhamos no contexto da Web, é necessário uma atenção redobrada quanto aos direitos autorais, tendo em vista que o processo de copiar e colar se intensifica, entrando numa ilusão de que, aquilo que está disponível na Internet, não possui um autor. Por isso, o trabalho da coordenação de curso e tutores é essencial para combater esse processo, esses não podem se ausentar do processo, pois a sensação de estar sozinho no curso, denunciada por Marta no excerto 1, pode ser um fator motivador do plágio. É necessário alertar e punir, buscando contribuir para a mudança das concepções de pesquisa, leitura, produção e autoria; estimulando criações individuais (SILVA, 2008).

\footnotetext{
29 "Você não teve tempo para realizar a atividade de escuta? O que aconteceu que as suas respostas são cópias quase perfeitas das respostas de outro estudante? Em uma delas, a do item "b", você não mudou absolutamente nada. Levando em conta isso, não posso te avaliar atribuindo a nota máxima de 10,0, já que esta atividade, que é individual, não foi realizada como deveria. Esteja atenta para não cometer a mesma falha nas próximas atividades. Busque fazê-las você mesma e com antecedência, só assim poderá desenvolver seu espanhol, aprendendo com seus próprios erros. Se se repetir a "cópia" de respostas entre alunos nas próximas atividades INFELIZMENTE a nota será 0,0 para os dois."
} 


\subsubsection{Habilidades linguísticas e formação de professores}

Após entender a motivação dos estudantes para a realização do curso em análise, ainda mapeando o perfil dos estudantes para chegar ao trabalho realizado com a oralidade no curso, foram coletadas informações sobre a aprendizagem e a importância das habilidades linguísticas no processo de formação e, consequentemente, na identidade de professor.

\section{Conhecimento atual da $L E$}

Os estudantes foram questionados sobre como qualificam o seu conhecimento atual da língua espanhola, exatamente para contrastar com os dados do ingresso no curso, expostos anteriormente. As respostas dos estudantes apontam para um positivo crescimento no conhecimento da língua, conforme gráficos a seguir. Nota-se que, nos estudantes de segundo semestre, apesar do crescimento, esse se dá, em geral, apenas numa escala acima daquela em que o estudante ingressou no curso, ou seja, aquele estudante que considerava o seu conhecimento como "pouco", no contexto atual o considera como "mediano"; já os alunos do sétimo semestre consideram o seu conhecimento como mediano ou alto.

Analisar essas questões se faz necessário diante do contexto atual em que se verifica que os alunos aprendem a LE durante a graduação (BARCELOS 1995; FERREIRA 2012). As informações dos gráficos não estão inicialmente apoiadas na oralidade, pois outras informações sobre esse ponto serão expostas mais adiante, mas, podemos apoiar esses dados no entendimento de Pinilla Gómez (2005) de que as habilidades estão interligadas, e o conhecimento da língua seria a soma de todas as habilidades. 


\section{Gráfico 3 - Conhecimento atual da língua espanhola em alunos do $2^{\circ}$ semestre}

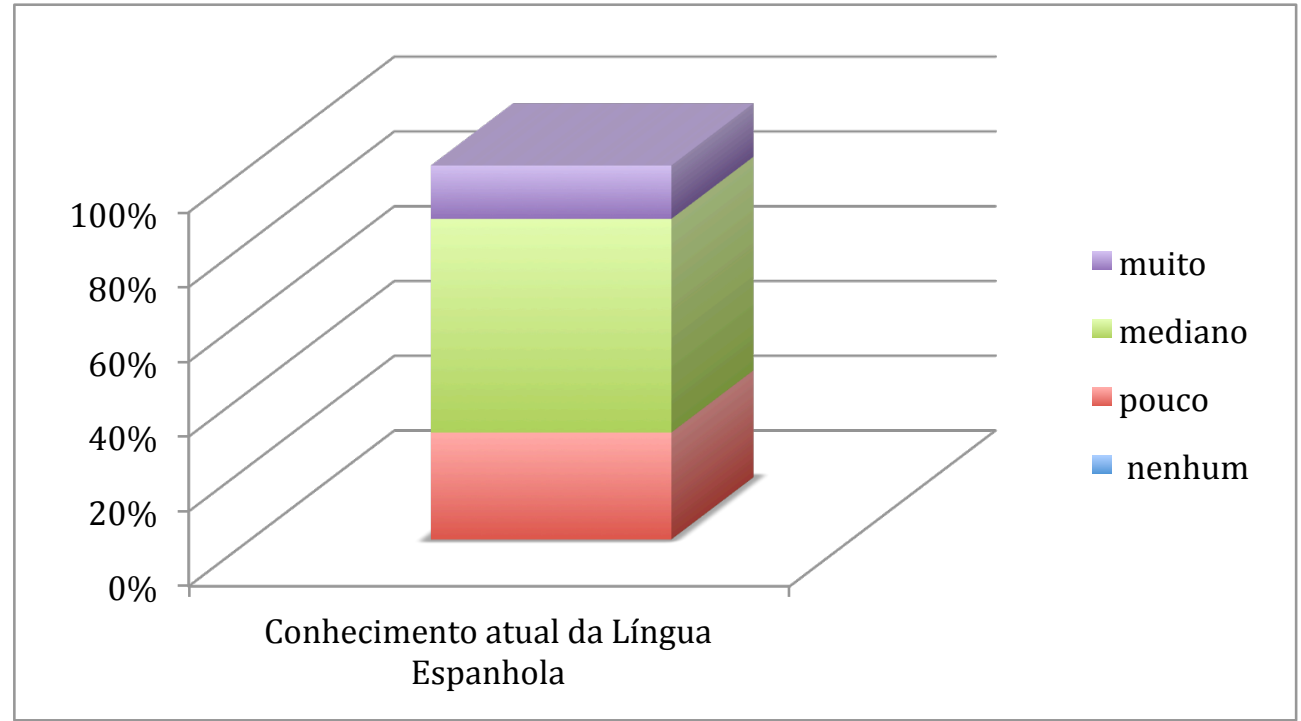

\section{Gráfico 4 - Conhecimento atual da língua espanhola em alunos do $7^{\circ}$ semestre}

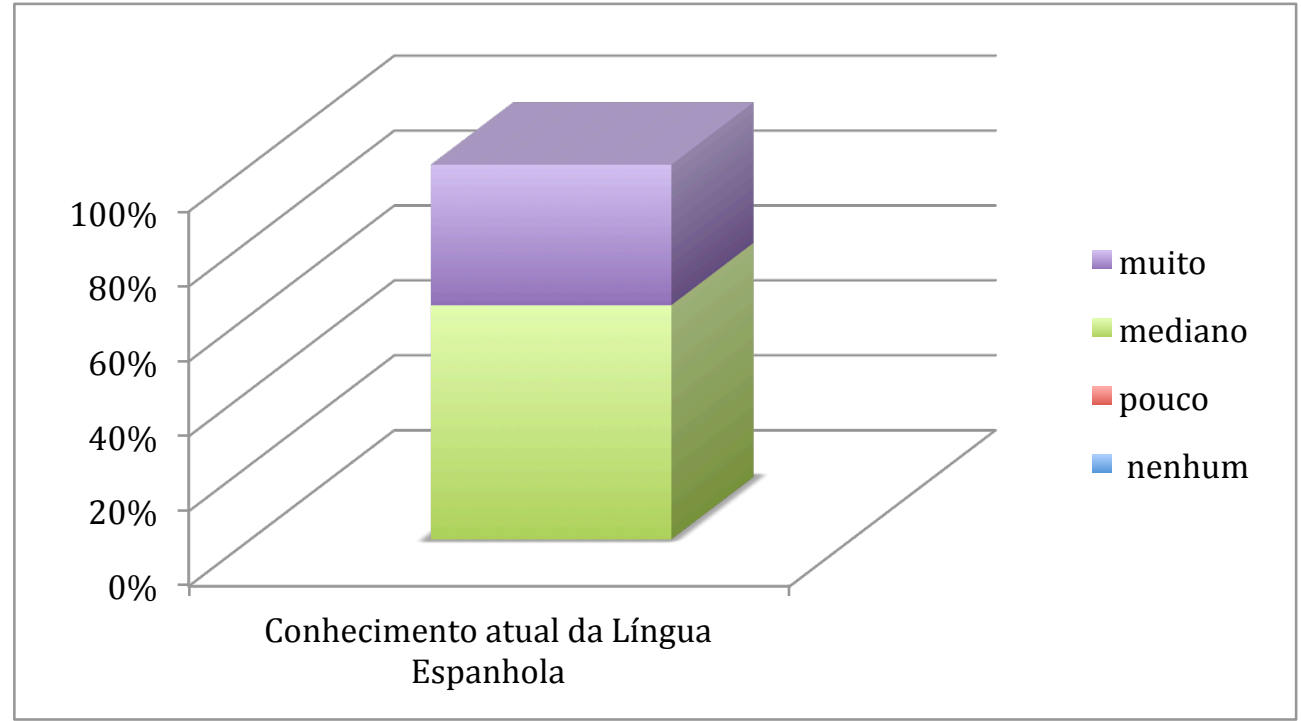

A partir da observação dos gráficos é possível verificar um crescimento no que se refere ao conhecimento da LE estudada, o que aponta que o ensino de línguas na modalidade EaD não é apenas uma possibilidade, mas uma realidade, assim como afirma Paiva (2001; 2015). No entanto, esses dados, no estudo de caso em questão, nos mostram o todo, como os estudantes se 
veem em relação à língua espanhola como um todo, nos tópicos a seguir será possível verificar uma parte do processo, no caso a oralidade.

\section{Habilidade mais importante para um professor de LE}

Os estudantes apresentaram a sua opinião sobre qual seria a habilidade mais importante para um professor de LE. Por meio dessas respostas será possível começar a separar as partes do todo, ou seja, por meio do entendimento dos estudantes sobre as habilidades será possível situálos dentro do processo de aprendizagem da língua, além de poder identificar a habilidade relacionada à identidade de professor.

\section{Gráfico 5 - Habilidade mais importante segundo os alunos do $2^{\circ}$ semestre}

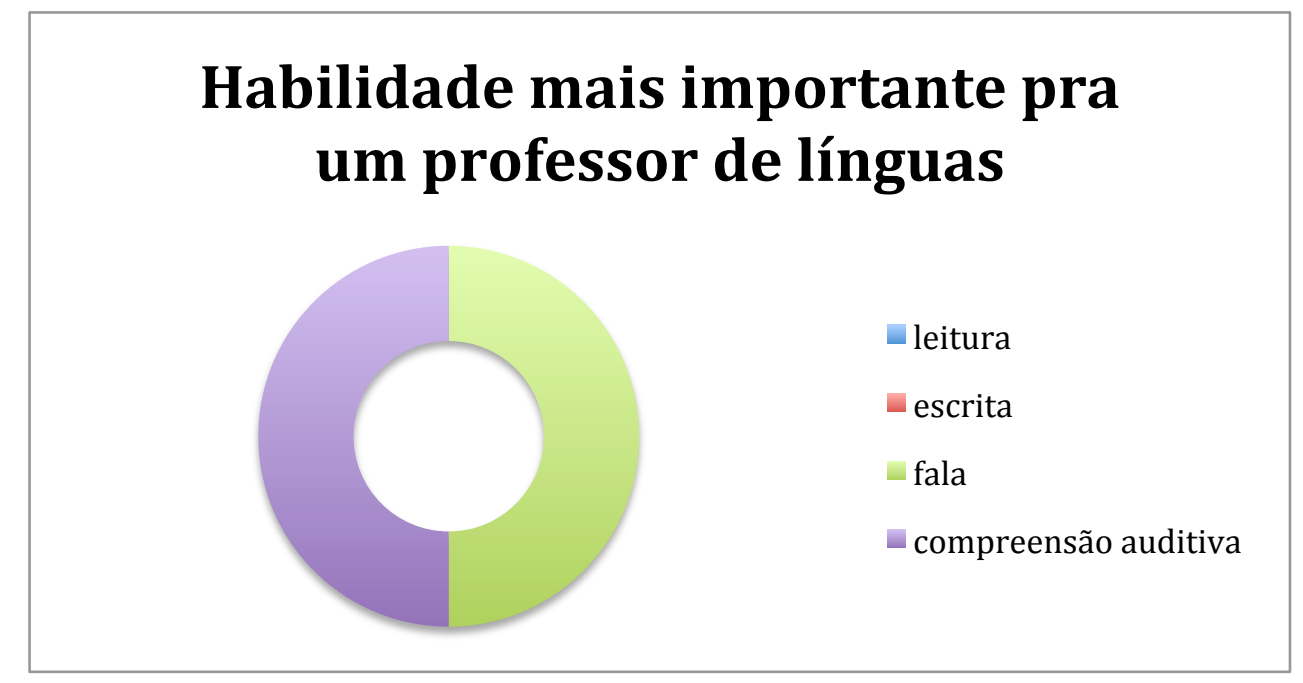

Conforme gráfico acima, os estudantes do segundo semestre se dividem entre a oralidade e a compreensão auditiva, processos que estão intimamente interligados, precisando o estudante de um input dado pela compreensão auditiva para que haja a produção de oralidade (MARTÍNEZ 2005). Essa informação também revela que, para esses estudantes, ao se tornar professor da LE estudada, o indivíduo deve ser capaz de lidar com situações de comunicação oral, situações essas em que, em geral, o indivíduo não possui suporte de ferramentas como dicionários ou programas de tradução.

Já o gráfico com os dados dos alunos do sétimo semestre, a seguir, revelará uma opinião diferente. Esses alunos se dividem entre as habilidades de escrita, oralidade e compreensão auditiva, com uma prevalência da oralidade, seguida do processo de domínio da escrita. 


\section{Gráfico 6 - Habilidade mais importante segundo os alunos do $7^{\circ}$ semestre}

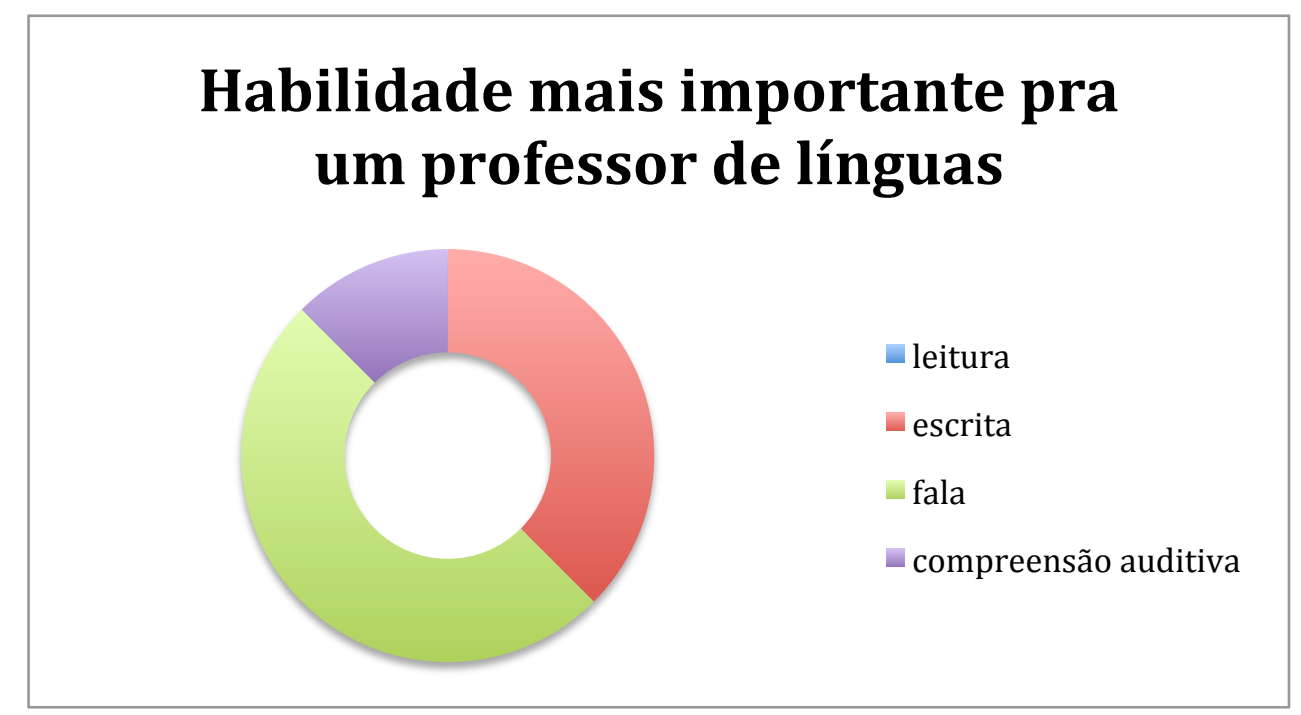

Os dados acima, portanto, revelam a preocupação dos estudantes com a oralidade, no entendimento de que um bom professor é aquele que consegue se expressar oralmente, além de possuir uma boa compreensão auditiva e escrita. Para esses estudantes a identidade de professor está relacionada às habilidades de produção (escrita e fala). Uma possibilidade de interpretação para esse foco dos estudantes em relação à escrita pode estar relacionada à forma como os estudantes estão aprendendo a língua. As observações no ambiente virtual e as entrevistas, como o excerto a seguir, demonstraram um foco de aprendizagem na questão gramatical, priorizando exercícios de escrita com base em regras gramaticais.

[4] Eu espero que tenha um foco maior na oralidade nas próximas [disciplinas] porque agora a gente vai pagar espanhol III, IV... que o foco seja mais na oralidade até porque acredito que agora nessas [disciplinas] I e II a gente viu bastante regra e a gente precisa trabalhar essas regras porque senão a gente vai esquecer de novo. (Vanessa $-2^{\circ}$ semestre)

Apesar de se tratar de uma estudante do segundo semestre, o exposto por ela é confirmado durante as observações das disciplinas de língua espanhola ofertadas no ambiente virtual. Esse tema será aprofundado no tópico 4.1.4. 
Habilidade mais dificil de ser aprendida

Por último, para contrapor as respostas sobre a habilidade mais importante, há informações sobre qual seria a habilidade mais difícil de ser aprendida. Assim como no item anterior, as opiniões dos estudantes do segundo e do sétimo semestre são distintas, conforme gráficos a seguir:

Gráfico 7 - Habilidade mais difícil de ser aprendida segundo os alunos do $2^{\circ}$ semestre

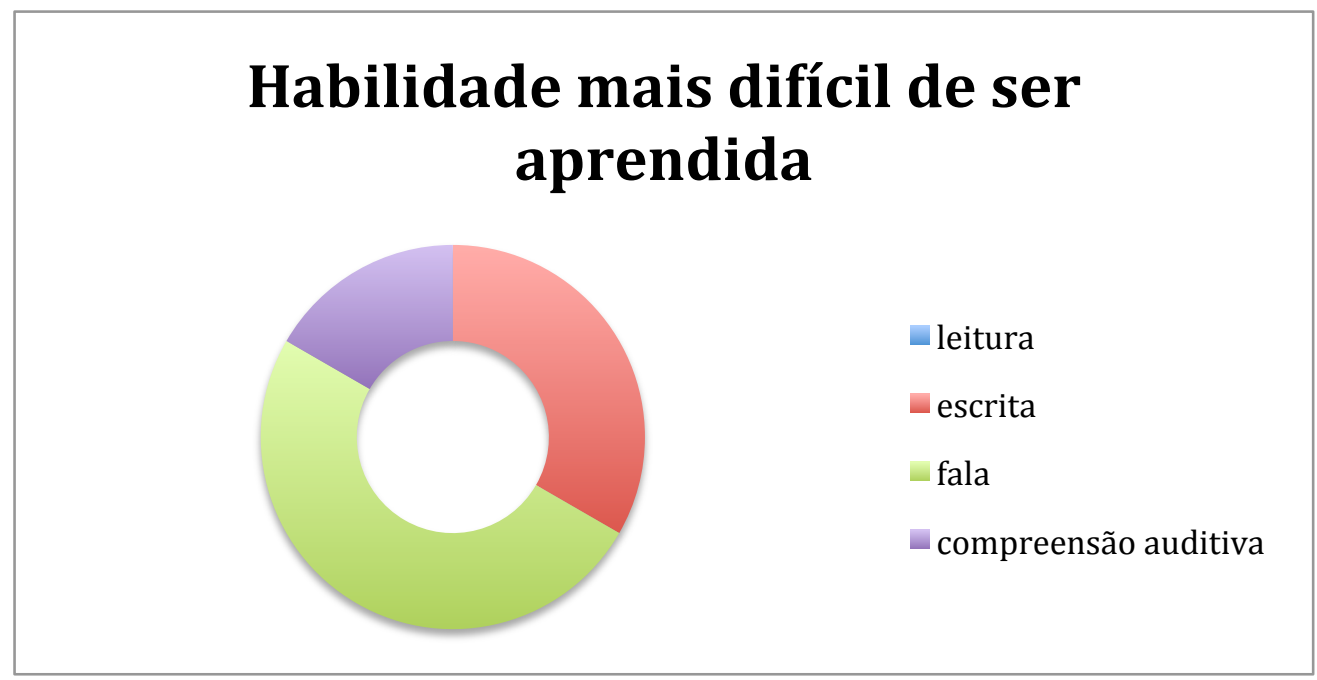

Gráfico 8 - Habilidade mais difícil de ser aprendida segundo os alunos do $7^{\circ}$ semestre

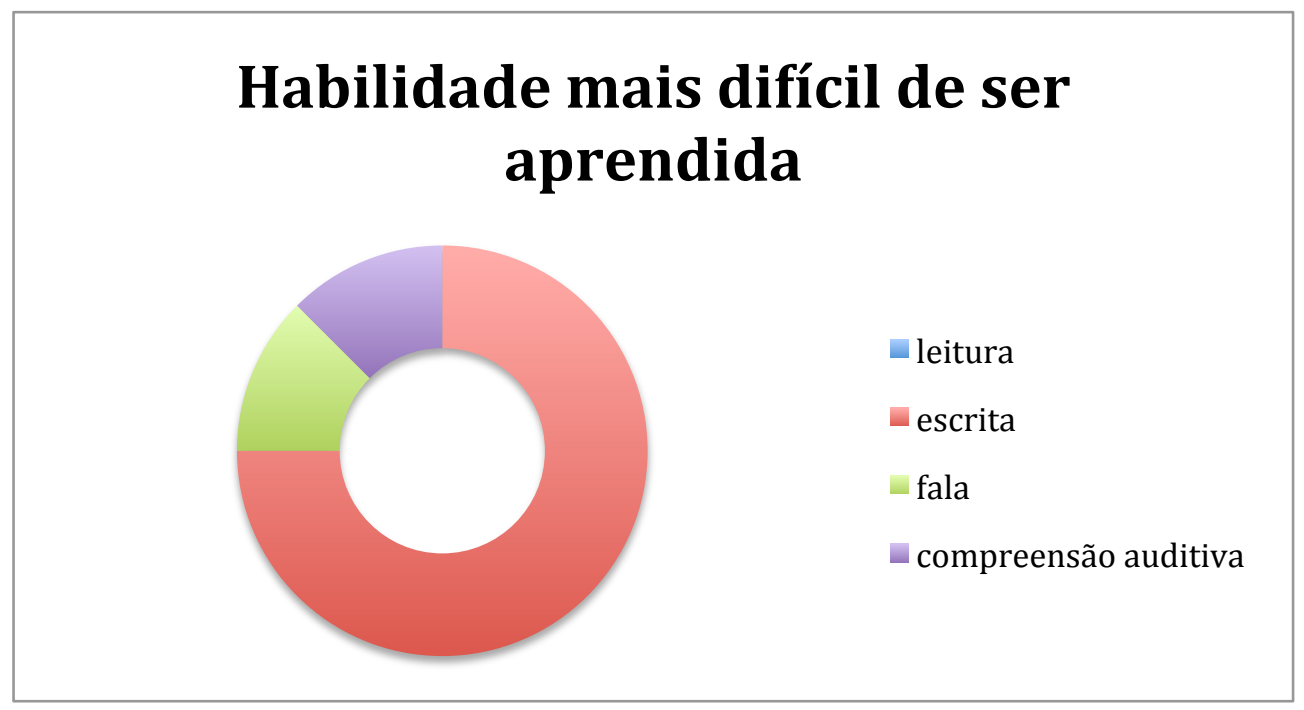


Enquanto os estudantes do segundo semestre consideram que a oralidade é a habilidade mais difícil de ser aprendida, os estudantes do sétimo semestre apontam para a escrita. Os resultados dos estudantes do sétimo semestre, em relação à habilidade mais difícil de ser aprendida, causaram espanto, tendo em vista que a escrita é a habilidade mais trabalhada dentro da plataforma virtual do curso, juntamente com a leitura. Talvez exatamente por essa prática exaustiva, em que o processo de produção e correção é mais intenso, é que os estudantes percebem com mais intensidade a dificuldade no domínio da habilidade. Mais uma vez, noto que as habilidades de produção (escrita e fala) são as que ganham destaque no processo de se dominar uma LE, inclusive na identidade de ser professor; o professor portanto, deve ser um agente ativo, que produz, dominando a fala e a escrita da língua, habilidades essas que estão relacionadas às compreensões leitora e auditiva, sendo essas o input para a produção das anteriores (MARTÍNEZ 2005; PINILLA GÓMEZ 2005).

Durante as entrevistas, a estudante Marta (segundo semestre) começa a revelar o foco de aprendizagem das habilidades no contexto de $\mathrm{LE}$ na $\mathrm{EaD}$ ao afirmar que "realmente você aprende a escrever e a ler, mas a falar fica complicado". No tópico a seguir, apresento mais registros e análises em relação ao trabalho com a oralidade dentro do curso em análise.

\subsubsection{O trabalho com a oralidade}

Nesse tópico apresento os registros e análises ligados ao trabalho com a oralidade no curso em questão. Para entender as atividades propostas nas disciplinas e as questões apresentadas pelos estudantes durante as entrevistas, é necessário descrever a organização das disciplinas e estrutura dentro do ambiente virtual.

\section{Apresentação das disciplinas, trabalho dos tutores e materiais utilizados}

As disciplinas observadas estão organizadas em formato de semanas, com instruções e materiais sempre em língua espanhola. Esse fator é positivo, permitindo um contato direto com a língua-alvo, tendo em vista que a aprendizagem de uma LE está condicionada à exposição à língua que se pretende aprender. (ALMEIDA FILHO 2008; BERGILLOS 2005).

Cada disciplina observada possui ao menos um professor-tutor. Isso quer dizer que, de acordo com o PPC do curso, "a tutoria é realizada por professores capacitados em EaD para 
conhecer suas funções e responsabilidades e o sistema de tutoria que utiliza. Ela pode ocorrer individualmente ou em grupos". As disciplinas observadas, em geral, possuíam mais de um tutor.

Cada polo possui um tutor presencial, que, de acordo com o PPC, "está disponível todos os dias da semana, inclusive aos sábados, e visa, sobretudo, à orientação de estudos e ao acompanhamento do estudante na sua adaptação à modalidade de ensino" (p. 42). No entanto, a figura do tutor presencial aparece para mim apenas no momento dos encontros presenciais (aplicação das provas), não interagindo, portanto, dentro do ambiente virtual de aprendizagem.

O curso como um todo possui material pré-definido para cada uma das disciplinas, mas isso não impede que o professor faça recortes nesse material e/ou adicione novos elementos. $\mathrm{O}$ material pré-definido é entregue aos estudantes no formato de livro impresso e/ou CD do semestre. Nessa última opção, o CD possui o material de todas as disciplinas do semestre. Em uma breve análise do material ${ }^{30}$ é possível notar que ele aparece de forma contextualizada, conforme o exemplo a seguir; no entanto, ele é apresentado em arquivo não editável. Por isso, no caso das tarefas (apenas as não avaliativas), os estudantes não poderiam responder no arquivo em que receberam.

\footnotetext{
${ }^{30}$ Por ser um material livre, que possui links para baixar na internet, decidi por, juntamente com o PPC do curso, disponibilizar esse material para consulta em uma pasta virtual que pode ser acessada pelo link:

https:/www.dropbox.com/sh/jt78w4ora69c8xn/AAAfSWtPenwiI0SxtuzZ8Gbra?dl=0
} 


\title{
Figura 7 - Texto sobre a cidade de Natal
}

\author{
Natal, ciudad sede del Mundial de Fútbol de 2014
}

Fig. 01

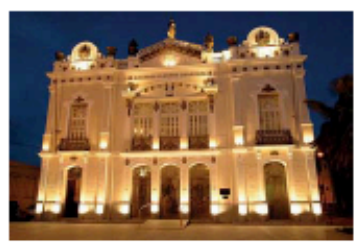

Teatro Alberto Maranhão

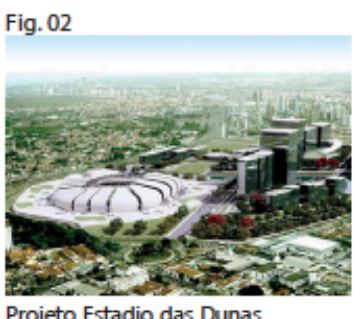

La historia de la ciudad de Natal empieza el 25 de diciembre de 1599 cuando una otra expedición portuguesa, al comando de Mascarenhas Homem y Jerônimo de Albuquerque, arriba a la costa potiguar con el objetivo de expulsar a los franceses y reconquistar la capitanía. Doce días se pasan y exactamente el 06 de enero de 1598, como una estrategia de defensa contra el ataque de los indios y de los corsarios franceses, los portugueses comienzan la construcción de un fuerte al que denominan de Fortaleza dos Reis Magos. Una vez que se concluye la obra, luego se forma un poblado al que se le designa, según dicen algunos historiadores, primero el nombre de Cidade dos Reis y posteriormente, Cidade do Natal.

Más de cuatro siglos transcurren y Natal es hoy en día, una ciudad moderna y alegre que sigue en desarrollo cada día, engalanada por el río, el mar, las dunas, las lagunas, sus playas y mucha vegetación, lo que le da un colorido y una vista inigualable. Con una población a la fecha, de unos novecientos mil habitantes y una óptima hospitalidad natural de su pueblo, recibe cada año unos dos millones de turistas brasileños y extranjeros. Para ello, consta con una red hotelera de calidad, esparcidos a lo largo de los $9 \mathrm{~km}$ de la Via Costeira - una costanera construida entre el Parque das Dunas y el Océano Atlántico. También, cuenta con muchos requintados restaurantes con destaques culinarios tanto regional como internacional.

El 31 de mayo de 2009, el Comité Ejecutivo de la Federación Internacional de Fútbol Asociado, universalmente conocida por su acrónimo de FIFA, se reúne en Nassau, Bahamas y elige la ciudad de Natal, como una de las 12 ciudades sedes del Mundial de Fútbol 2014, junto a Río de Janeiro, San Pablo, Belo Horizonte, Brasilia, Porto Alegre, Curitiba, Manaus, Fortaleza, Recife, Salvador y Cuiabá.

Dicho evento tiene lugar del 13 de junio al 13 de julio de 2014, y para ello, se reconstruye el Estadio Machadão, en su totalidad que pasa a llamarse Estadio das Dunas, con una capacidad de cuarenta y cinco mil personas.

De esta forma, la ciudad de Natal, orgullo de los natalenses, conocida por ser una de las capitales más seguras de Brasil, con uno de los aires más puro de las Américas y porque es la capital brasileña que se encuentra más cercana de Europa y de la isla Fernando de Noronha, abre sus puertas al mundo, mucho más resplandeciente y pintoresca de lo que ella suele ser.

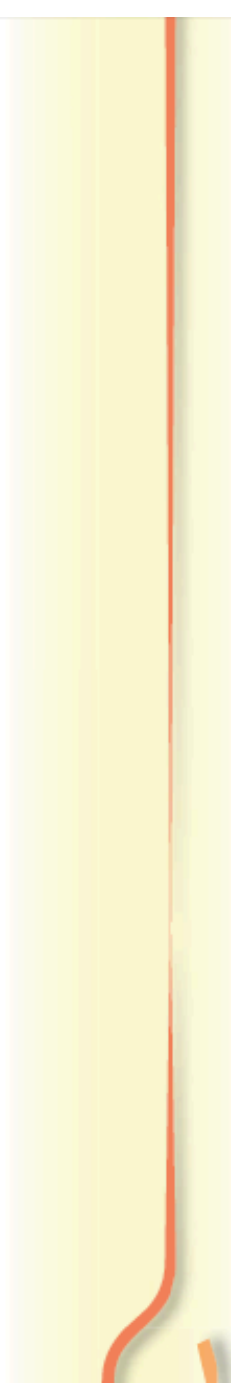

Fonte: BARRETO 2012, p. 04

O texto da figura 7 faz parte do material da disciplina Língua Espanhola II e me chamou atenção por trazer para o contexto de LE a cultura brasileira, mais especificamente a capital do estado no qual o curso é realizado, o que, de acordo com Bergillos (2005) é um fator motivacional, ou seja, aproximar o ensino à realidade do estudante.

No entanto, apesar de tratar temas diversificados e exercícios que contemplam interpretação de textos e reflexão, o material também traz exercícios puramente gramaticais, como o que se apresenta na figura 8 , apresentada a seguir. 


\section{Figura 8 - Exercício gramatical}

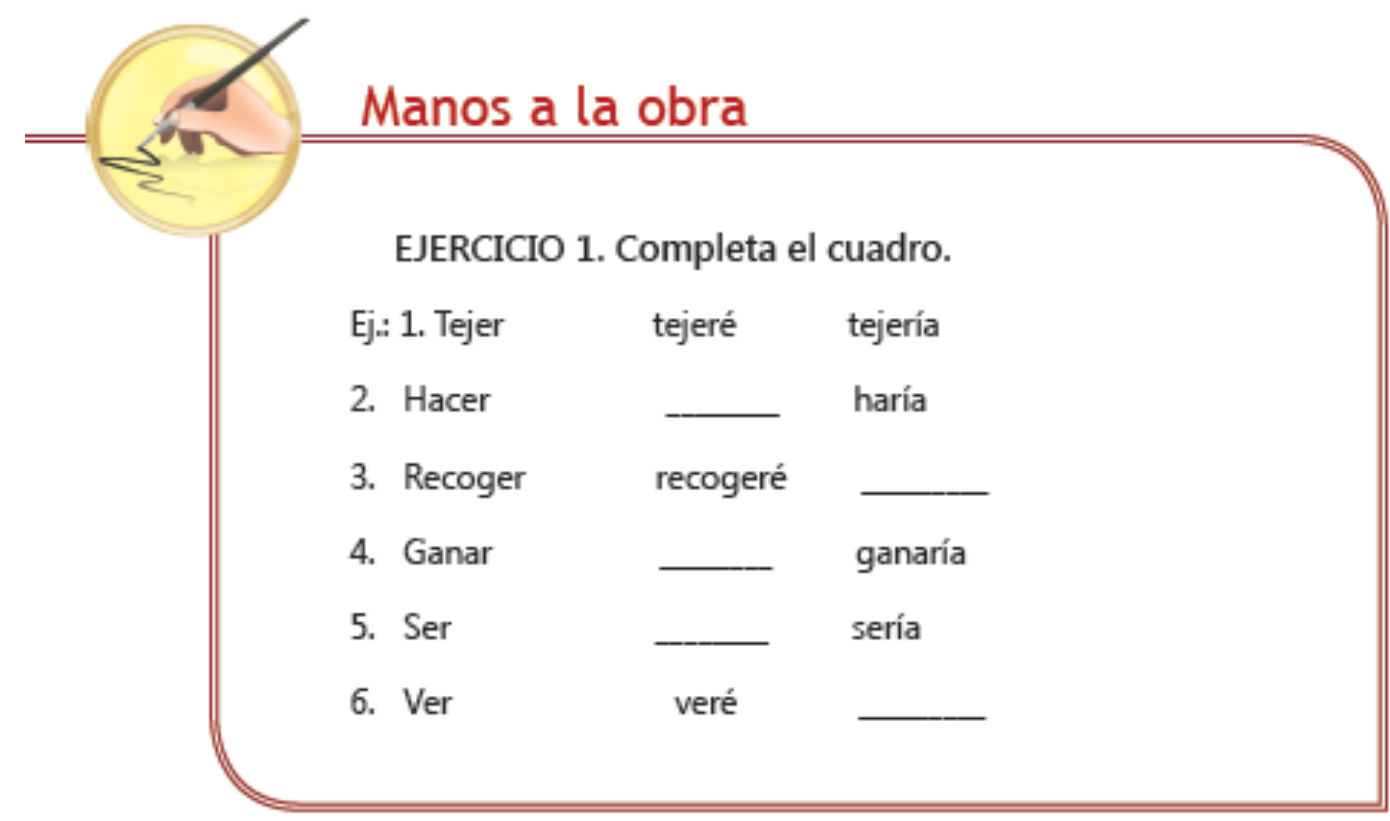

Fonte: GÓMEZ, O. 2012, p. 12

Outro ponto de destaque no material utilizado e organização da plataforma como um todo é que, quando há atividades de escuta, o áudio não está disponível na plataforma, apenas no CD de materiais do semestre. O material de texto é disponibilizado no ambiente virtual, mas o fato de não haver um link direto para os outros recursos de áudio e vídeo prejudica o acesso, o que muitas vezes desestimula o estudante.

Durante as entrevistas, uma das estudantes se queixou da falta de material impresso no semestre, afirmando que:

[5] eles não disponibilizam vídeo-aula, e isso tem dificultado bastante o aprendizado da gente, e outra coisa, material esse semestre não veio impresso, então está sendo muito difícil. (Leila $-2^{\circ}$ semestre).

Nesse sentido, há dois olhares, o primeiro relativo à dependência dos estudantes ao material impresso, mesmo se tratando de um curso na modalidade $\mathrm{EaD}$; e o segundo é que essa dependência pode ser um fator positivo, pois esse material impresso pode ajudar no processo de domínio da escrita em língua espanhola, sendo um fator motivacional para que os estudantes leiam e façam anotações diretamente no material. 
Com relação à oralidade, quando falamos de apresentação e organização das disciplinas, durante a apresentação na disciplina de Língua Espanhola II, uma das tutoras afirma que serão trabalhadas as quatro habilidades: compreensão auditiva; compreensão leitora; expressão oral e expressão escrita, conforme imagem a seguir (grifo meu).

\section{Figura 9 - As habilidades na disciplina de Língua Espanhola II ${ }^{31}$}

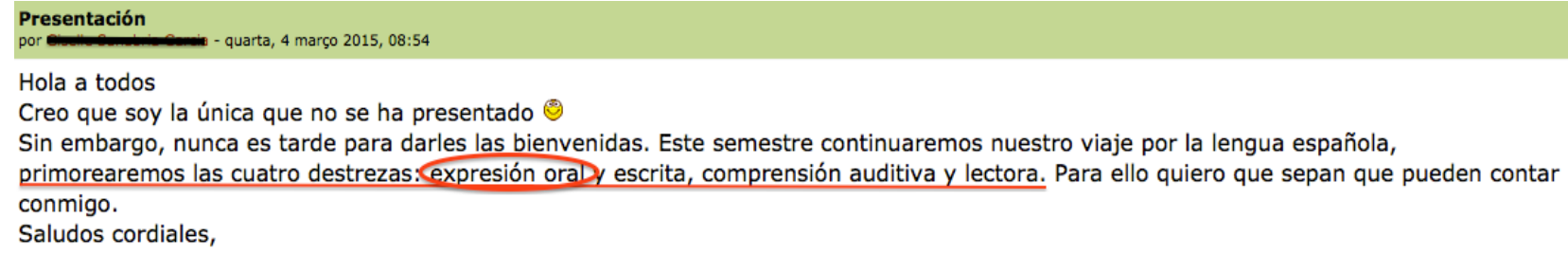

No caso da disciplina Língua Espanhola IV, na ementa consta que a disciplina tem o objetivo de "Compreender e produzir textos complexos sobre temas variados. Desenvolver a competência comunicativa e as habilidades de compreensão e produção oral e escrita".

Ao compararmos as ementas das disciplinas, as atividades propostas nas disciplinas observadas e o que se espera do estudante formado pelo curso (descrito em seu PPC e exposto aqui na página 58), o cenário que temos é da afirmação nos documentos de uma formação completa em termos de língua, já que o PPC afirma que o que se espera do estudante que conclui o curso é que ele faça "uso das quatro habilidades linguísticas orais e escritas (compreensão, escrita, compreensão auditiva, expressão escrita e expressão oral) com proficiência, a fim de produzir discursos (escritos e orais em situações de comunicação diversas)", mas na prática há falta de subsídios para se atingir a formação desejada. Essa informação se confirmará nos tópicos a seguir.

Apesar dessas afirmações, as atividades são, em maioria, relacionadas às habilidades escritas. A organização das atividades, recursos disponíveis e percepções dos estudantes sobre as atividades serão expostas no tópico a seguir.

\footnotetext{
31 “Olá a todos

Acredito que sou a única que não se apresentou.

No entanto, nunca é tarde para dar as boas-vindas a vocês. Este semestre continuaremos nossa viagem pela língua espanhola, dando prioridade às quatro habilidades: expressão oral e escrita, compreensão auditiva e leitora. Para isso, quero que saibam que podem contar comigo.

Saudações cordiais."
} 


\section{Recursos disponiveis para a prática da oralidade}

Vídeos: o comentário anterior da estudante Leila (excerto 5) sobre a falta de vídeos na plataforma se confirma durante as observações. Na disciplina de Língua Espanhola II não há vídeos ou áudios disponíveis na plataforma. Ao final de alguns módulos do material há sugestões de links, mas nenhum está inserido na plataforma ou descrito como de acesso obrigatório; há apenas uma exceção: um vídeo que aparece como material complementar na sexta semana do curso. No caso da disciplina de Dialetologia do Espanhol, disciplina que deveria focar nas diferentes pronúncias e possibilidades da língua falada, ainda possuem pouca quantidade de vídeos, principalmente vídeos que mostrem as diferentes formas de pronunciação das palavras. Em contraponto, vídeos aparecem no esforço muito positivo por parte dos tutores para fazer os estudantes entenderem os conteúdos. Por fim, no caso da disciplina de Língua Espanhola IV, houve a sugestão do filme "Nueve Reinas", e o link para o filme estava disponível para os estudantes assistirem e depois responderem a questões relacionadas. No entanto, houve queixa de estudantes sobre a dificuldade de entender o filme, já que não havia legendas.

\section{Figura 10 - Dificuldade de compreensão ${ }^{32}$}

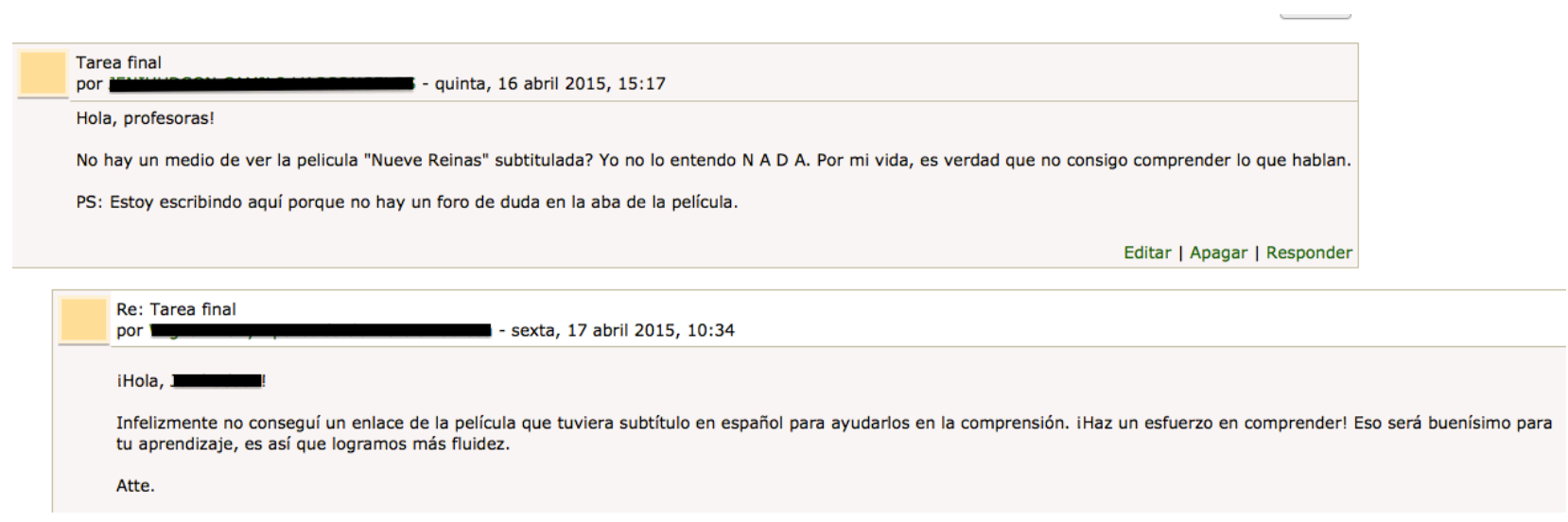

\footnotetext{
32 “Oi professoras! Não existe um meio de ver o filme "Nueve Reinas” legendado? Eu não entendo N A D A. Juro por minha vida, é verdade que não consigo compreender o que falam. P.S.: Estou escrevendo aqui porque não há um fórum de dúvidas na aba da tarefa do filme."

“Oi! Infelizmente não consegui um link do filme que tivesse legenda em espanhol para ajuda-los na compreensão. Faça um esforço para compreender. Isso será muito bom para a sua aprendizagem, é assim que conseguimos mais fluência. Atenciosamente."
} 
Esse fato comprova a deficiência dos estudantes em termos de compreensão auditiva, principalmente por se tratar de um estudante do sétimo semestre. Apesar de a disciplina ser ofertada para alunos do quarto semestre, o estudante em questão foi rastreado e observei que ele já está no sétimo semestre do curso. A falta de compreensão após sete semestres no curso revelam lacunas na formação. Com base nas minhas observações no ambiente virtual, os estudantes são capazes de ler e escrever em língua espanhola, mas apresentam dificuldades na compreensão oral e, provavelmente, na produção oral. Utilizo o termo "provavelmente" por não haver identificado atividades de prática oral para esse grupo dentro do ambiente virtual. Portanto, essa dificuldade com as habilidades orais está relacionada ao tipo de práticas que foram propostas durante esses semestres.

Chats: As disciplinas de Língua Espanhola II e Dialetologia do Espanhol contavam com a ferramenta chat online na plataforma virtual. No caso da primeira disciplina, havia a possibilidade de uma hora de chat todos os dias (em horário determinado), mas de participação optativa. Apesar dessa possibilidade diária, a adesão dos estudantes foi muito pequena, ocorrendo poucas sessões durante a disciplina. Já no caso da disciplina de Dialetologia, não havia previsão de chats semanais; apenas no módulo de revisão houve uma sessão, e esta contou com a participação de alguns estudantes. O fato de haver atividades com pouca participação dos estudantes levanta um olhar sobre a questão da autonomia e o papel dos agentes no processo de ensino-aprendizagem. Esse tema será tratado em um tópico mais adiante deste trabalho.

Em termos de oralidade, mesmo que o chat seja um recurso com foco na escrita, ele estimula o processo de comunicação, mais especificamente a competência comunicativa na língua, propondo um uso da língua para situações reais (ALMEIDA FILHO 2005). Além disso, o chat pode ser o início do processo de prática da oralidade, podendo haver a evolução dos estudantes para uso de outras ferramentas que permitem comunicação oral, como o Skype. Essa visão também foi compartilhada pelos estudantes, que, durante os questionários, apontaram os chats como recursos que ajudam no desenvolvimento e prática da oralidade.

\section{Atividades para a prática da oralidade}

Retomando a teoria de Pinilla Gómez (2005) sobre as possíveis atividades para se desenvolver a oralidade, ela afirma que o professor deve ter em mente a ampla variedade de atividades, observando cada momento do programa de ensino e cada objetivo. As atividades 
exemplificadas pela autora foram: a) diálogos ou conversações; b) entrevistas; c) dramatizações; d) exposições de temas; e) debates; f) conversações telefónicas e mensagens a serem gravadas; e g) atividades de caráter lúdico.

Por se tratar de um contexto $\mathrm{EaD}$, algumas dessas atividades resultam mais difíceis de serem praticadas, como as dramatizações. Apesar disso, outras são possíveis, tendo apenas que se levar em conta fatores como organização e perfil dos estudantes.

As observações no ambiente virtual, no entanto, revelaram que as atividades eram predominantemente escritas e com conteúdo gramatical, em geral, constituindo-se em exercícios para completar frases. Na disciplina de Língua Espanhola IV apenas uma atividade foi a combinação de escrita com compreensão auditiva. As provas presenciais das disciplinas observadas, realizadas no polo, também são apoiadas em questões unicamente gramaticais. Os estudantes foram ao polo unicamente para realizar a prova e ir embora, não houve um trabalho de reflexão ou revisão sobre os temas.

Apesar de todo esse contexto, a disciplina de Língua Espanhola II apresentou cinco atividades de produção oral, descritas a seguir:

1. A primeira atividade consistia em o estudante gravar uma breve apresentação sua (de no mínimo um minuto), em que falasse sobre seus gostos, família e características físicas ou de sua casa, sua rotina e seus planos futuros, mas a atividade não foi contabilizada como avaliativa; tampouco aparece feedback para os estudantes por parte do professor.

2. A segunda atividade consistia em o estudante gravar a sua biografia; ele poderia imaginar ter mais idade e contar a sua história. Essa atividade também possuía o mínimo de tempo de gravação, no caso, pelo menos um minuto de gravação. Ao contrário da atividade anterior, nesta os estudantes receberam nota e feedback do seu material.

3. A terceira atividade consistia em gravação sobre o tema amor e as suas enfermidades. $\mathrm{O}$ estudante realiza a gravação de pelo menos um minuto sobre o que seria o "mal de amor" e os possíveis remédios, podendo também contar uma história sua para ilustrar o tema. Nessa atividade os estudantes também receberam feedback da sua produção oral. 
Importante ressaltar que o feedback, em todas essas atividades orais, é feito também oralmente, portanto a professora grava os comentários (em língua espanhola) sobre o desempenho e detalhes a serem melhorados pelo estudante.

A seguir a transcrição de um dos feedbacks da professora:

\begin{abstract}
${ }^{33}$ Hola! Felicitaciones por tu tarea, está muy buena. Para tu aprendizaje haré algunos comentarios, ¿sí? Sobre la gramática, has cometido pequeños equívocos, por ejemplo, el verbo "ser" en presente de indicativo, tercera persona de singular, se conjuga "es", entonces la frase correcta seria: "el mal de amores es muy común". Además debe decir "una de las consecuencias", pues no hay la contracción "das" en español. Sobre tu pronunciación, te recuerdo que la "r" siempre vibra, así debes decir "[řeN di 'mjeN to]" (rendimiento), "[řru 'ti na]" (rutina). ¿Comprendes?. Además, en español no existe el sonido /z/, así que debe pronunciar "[fi si kos]" (físicos), "[in 'klu so]" (incluso). Te aclaro aún que cuando la palabra se escribe con una "p" e una "s" juntas no se pronuncia la "p". Lo correcto entonces seria "[p si ko 'lo xi kos]" (psicológicos). Con relación a tu vocabulario, te aclaro solamente que las palabras correctas son "también" y "problemas". Es eso, ya hablas muy bien, si sigues practicando hablarás con más fluidez y con más velocidad. Es importante que escuche su grabación para identificar lo que te digo aquí.
\end{abstract}

O feedback dado pela professora é individual, extremamente detalhista e rico, contemplando aspectos de pronúncia, gramática e vocabulário. Esse tipo de prática é um excelente exercício para o desenvolvimento da oralidade, e da LE como um todo, pois o estudante pode visualizar os seus erros e aprender com eles, tendo consciência de seu processo

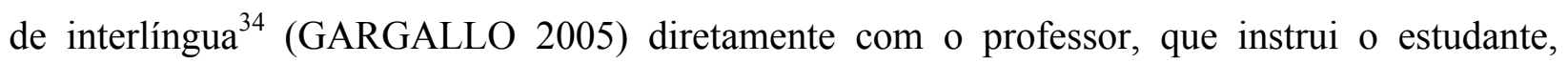
levando-o ao conhecimento numa prática motivacional. No entanto, é importante ponderar que o

\footnotetext{
33 “Olá! Parabéns pela sua tarefa, está muito boa. Para sua aprendizagem farei alguns comentários, certo?! Sobre a gramática, você cometeu pequenos equívocos, por exemplo, o verbo "ser" no presente do indicativo, terceira pessoa do singular, se conjuga "es", então a frase correta seria "el mal de amores es muy común". Além disso, deve dizer "una de las consecuencias", pois não há a contração "das" em espanhol. Sobre a sua pronúncia, relembro que o "r" sempre vibra, assim deve dizer "[řeN di 'mjeN to]" (rendimiento), "[ř̆u 'ti na]" (rutina). Certo?! Além disso, no espanhol não existe o som de /z/, portanto, deve pronunciar "[fi si kos]" (físicos), "[in 'klu so]" (incluso). Esclareço ainda que quando a palavra se escreve com um "p" e um "s" juntos não se pronuncia o "p". O correto então seria "[p si ko 'lo xi kos]" (psicológicos). Com relação ao seu vocabulário, esclareço somente que as palavras corretas são "también" e "problemas". É isso, você já fala muito bem, se seguir praticando falará com mais fluidez e com mais velocidade. É importante que ouça a sua gravação para identificar o que te digo aqui."

${ }^{34}$ De acordo com a autora, a interlíngua é o sistema linguístico do falante não nativo em uma determinada etapa do processo de aprendizagem, o qual se constrói de forma processual e criativa, e é observável na atuação linguística. (GARGALLO 2005, p. 393)
} 
feedback oral, no primeiro momento, pode causar dificuldade de entendimento do estudante, tema já relatado aqui, mas que com um efetivo exercício, e como o estudante tem a possibilidade de ouvir o áudio diversas vezes, essa prática se torna também um exercício para a habilidade de compreensão auditiva.

4. A quarta atividade consistia em gravação sobre o tema férias. $\mathrm{O}$ estudante deveria relatar (em no mínimo um minuto), o que ele gosta de fazer em seu tempo livre e quais são os seus planos para as próximas férias. Também houve feedback e nota para essa atividade.

5. A última atividade, assim como a primeira, teve temas diferentes para cada grupo. A gravação seria uma espécie de continuação da primeira atividade, em que o estudante faz uma breve apresentação sua (de no mínimo um minuto), em que fala sobre seus gostos, família e características físicas ou de sua casa, sua rotina e seus planos futuros. Com a divisão dos grupos, o grupo A falou sobre o primeiro tema (gostos, família e características físicas), enquanto o grupo B falou sobre o segundo tema (casa, sua rotina e seus planos futuros). Essa atividade também contou com feedback e nota.

A prática de gravação de áudio com feedback individual também em áudio aponta para um trabalho consistente de prática da oralidade no contexto da $\mathrm{EaD}$, no entanto, durante a navegação no ambiente, percebi que as atividades não eram realizadas por todos os estudantes. $\mathrm{Na}$ verdade elas não ficavam disponível para todos. Alguns alunos eram selecionados para realizar a atividade, que não consistia em uma atividade pré-definida da disciplina. Durante as entrevistas, estudantes afirmaram que se tratava de uma pesquisa de uma professora, e eles ganhavam pontos extras por sua colaboração. A situação será exposta e problematizada a partir da imagem a seguir, retirada do ambiente virtual, e das respostas obtivas nas entrevistas com os alunos do segundo semestre. 
Figura 11 - Atividades orais ${ }^{35}$

domingo, 22 março 2015, $11: 33$

Olá, bom dia. Bem, estou vindo novamente aqui para deixar registrado que a atividade do terceiro áudio não aparece para mim, assim como a segunda, embora no quadro de notas eu consiga visualizar essas mesmas atividades com notas zero é claro, pois não foram abertas para eu fazer. Gostaria então de saber se essas atividades serão abertas, se sim, quando serão abertas e se serão abertas todas de uma vez. Obrigada e aguardo realmente respostas esclarecedoras. Segue á o print da minha tela referente a sexta semana.

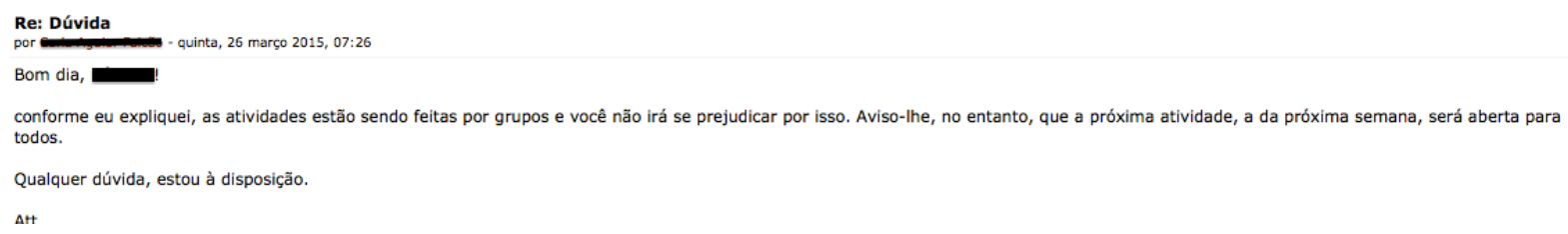

As únicas atividades de produção oral comum a todos os estudantes da disciplina eram as atividade de número um e número cinco. Essa observação se confirma durante as entrevistas.

[6] Essa atividade não é nem da disciplina, é uma pesquisa para uma professora e a gente assinou um termo no semestre passado e ela usa a disciplina de espanhol para fazer essa pesquisa com a gente.

$[\ldots]$

Tiveram quatro atividade orais, que foi exatamente para a pesquisadora, que ela está desenvolvendo a pesquisa, acho que é doutorado ou mestrado, não sei, a gente tinha assinado o termo, acho que faz dois semestres já que a gente assinou, aí ela sempre manda através da disciplina de espanhol pra gente gravar esses áudios. (Vanessa $-2^{\circ}$ semestre)

Portanto, na disciplina de Língua Espanhola II identifiquei as atividades de práticas orais descritas acima, mas, infelizmente, somente alguns estudantes tiveram acesso a elas. Inclusive, havia estudantes que nem sabiam que elas eram referentes a uma pesquisa, conforme nos demonstrou as informações da figura 11. Com relação à habilidade de compreensão auditiva na disciplina, não houve nenhuma atividade de escuta dentro da plataforma.

No caso da disciplina de Língua Espanhola IV, havia a previsão de uma atividade. Esta consistia em ouvir um áudio sobre conselhos para uma boa saúde, e o estudante deveria

\footnotetext{
35 "Olá, bom dia! Bem, estou vindo aqui para deixar registrado que a atividade do terceiro áudio não aparece para mim, assim como a segunda, embora no quadro de notas eu consiga visualizar essas mesmas atividades com notas zero é claro, pois não foram abertas para eu fazer. Gostaria então de saber se essas atividades serão abertas, se sim, quando serão abertas e se serão abertas todas de uma vez. Obrigada e aguardo realmente respostas esclarecedoras. Segue aí o print da minha tela referente a sexta semana".

"Bom dia. Conforme eu expliquei, as atividades estão sendo feitas por grupos e você não irá se prejudicar por isso. Aviso-lhe, no entanto, que a próxima atividade, a da próxima semana, será aberta para todos. Qualquer dúvida, estou à disposição".
} 
reproduzir esses conselhos. A atividade poderia ser feita de duas formas: ou transcrevendo de forma direta o conteúdo do áudio ou dando a sua interpretação. Essa atividade foi enviada para avaliação e atribuída nota ao estudante. Saí da observação na disciplina sentindo falta de atividades que desenvolvessem a competência comunicativa, exatamente pela ausência de atividades orais e/ou maiores atividades que incentivassem a produção escrita autônoma do estudante, como o que foi proposto no programa da disciplina. Esse contexto nos remete à afirmação de Santos (2013), que nos alertou sobre os discursos que afirmam uma prática voltada para a abordagem comunicativa, mas que, na realidade, ainda estão presos à abordagem gramatical.

Sobre as atividade para desenvolvimento da oralidade na disciplina de Dialetologia do Espanhol, não houve, durante toda a disciplina, uma atividade de produção oral ou atividade de escuta; apenas atividades de escrita, que ajudam a desenvolver o processo de comunicação escrita, mas não estão efetivamente ligadas à questão da oralidade.

As observações acima estão relacionadas à observação das disciplinas no ambiente virtual, e essa observação é apenas um recorte. Dessa forma, para melhor rastrear essas atividades durante o curso, os estudantes foram questionados sobre o que estão realizando ou atividades que realizaram no curso como um todo, a partir das quais fossem capazes de trabalhar o aspecto da oralidade. As opiniões dos estudantes confirmam o observado no ambiente virtual:

[7] a gente chega ao sétimo período com alunos que quase não possuem habilidade oral ou mesmo habilidade de escuta da língua, e me parece que seria essa a minha realidade também. (Carlos $-7^{\circ}$ semestre)

[8] Não vejo muita preocupação com a oralidade, e acredito que quem não tem um conhecimento tem uma dificuldade enorme, porque, por exemplo, no segundo semestre nós já estudamos fonética e fonologia e todo o material é em espanhol, então, assim, já é algo complicado de você aprender. (...) quem não tem esse conhecimento [prévio] acredito que teve uma dificuldade enorme, e eu não vejo muito incentivo com a oralidade, assim, não tem vídeo-aulas. (Vanessa $-2^{\circ}$ semestre)

[9] pra dizer que não, teve apenas uma. Somente o professor da matéria de mídias pediu pra gente gravar um áudio, mas não era avaliativo e a gente gravou por gravar. Ele não iria nos corrigir. (João $-7^{\circ}$ semestre)

[10] oralidade eu creio que tenho que fazer um curso depois, por fora, pra pegar a questão da oralidade. (Marta $-2^{\circ}$ semestre) 
Além da visível falta de atividades que coloquem a oralidade em foco, é possível observar, com base nos depoimentos dos estudantes, que os estudantes que chegam ao curso EaD com um conhecimento prévio da língua espanhola possuem uma melhor resposta ao curso. Isso levanta a teoria de que, para uma melhor formação no contexto de licenciatura em LE na modalidade $\mathrm{EaD}$, é necessário chegar ao curso com uma formação prévia da LE, o que vai de encontro à realidade presencial, em que os estudantes conseguem aprender a LE durante o curso de graduação.

Nesse contexto vale destacar o estudante Carlos, pois trata-se de um estudante que ingressou no curso de licenciatura já com um conhecimento da língua espanhola, afirmando já possuir, inclusive, um diploma internacional de conhecimento da língua. Esse estudante tem muito conhecimento do processo de aprendizagem de uma língua e faz comentários pertinentes sobre a sua experiência no curso EaD. Quando questionado sobre a sua capacidade de expressão em língua espanhola, ele afirma que "é boa, apesar de toda deficiência na possibilidade de praticar, que é uma coisa que me parece muito recorrente nos cursos à distância, o exercício das habilidades orais, inclusive de escuta, porque praticamente, na nossa realidade, não é praticado". O estudante complementa afirmando que:

[11] A gente tem mais dois semestres, e, baseado em tudo o que a gente já viu, na forma como o curso está organizado, eu não acho que vá existir, realmente, nenhum tipo de mudança nessa seara, eu acho que a gente vai continuar sem nenhum tipo de destaque à oralidade; esta foi praticamente nula durante todo $o$ nosso curso, eu não lembro de, com exceção de oficinas perdidas de 3 ou 4 horas que aconteceram acho que 4 vezes no curso inteiro - manhãs, a cada semestre uma manhã - onde se podia de fato ter contato com um professor real para praticar a língua, e aí, sim, praticar a oralidade e a escuta, por meio da EaD, isso nunca aconteceu, então os pouquíssimos momentos de oralidade que aconteceram foram exclusivamente presenciais, que, pela natureza da $\mathrm{EaD}$, quase não existem; então pelo ambiente virtual a oralidade não foi praticada; e eu acho que não vá ser daqui até o final do curso.

Parece-me inevitável apontar que não há um trabalho efetivo com a oralidade dentro do curso analisado, e as consequências dessa ausência de foco na oralidade aparecem nas percepções dos estudantes sobre a sua capacidade de se expressar oralmente em língua espanhola e também dar aulas na língua-alvo.

[12] Muito deficiente. Não consigo me expressar em língua espanhola. (João $7^{\circ}$ semestre) 
[13] Ainda tenho medo [de falar em espanhol]. (Paula $-2^{\circ}$ semestre)

No entanto, o retrato não é só de pessimismo. Mesmo com as dificuldades encontradas, alguns estudantes conseguem ver melhoras no seu processo de comunicação em língua espanhola, conforme os excertos a seguir:

[14] Ainda não está boa, mas está melhorando. (Angélica - $7^{\circ}$ semestre)

[15] Tá melhor que no início, porque não sabia nada. (Paula - 2ºmestre)

A realidade exposta é, portanto, bastante complexa, em que, apesar de não haver atividades que trabalhem a produção oral, alguns estudantes conseguem perceber uma melhora na sua capacidade de comunicação em LE. Essa melhora pode se justificar devido à atitude autônoma para progresso individual na língua que cada aluno tem, por conta de sua motivação na aprendizagem. Além disso, essa melhora também pode se justificar pela integração das habilidades linguísticas, tendo as demais habilidades o papel de suprir a falta de atividades de expressão oral (PINILLA GÓMEZ 2005).

\subsection{EXPONDO A NECESSIDADE}

Na primeira parte deste capítulo foram expostas informações e análises relacionadas à realidade do trabalho com a oralidade no contexto da EaD. A seguir, a partir da opinião dos participantes da pesquisa sobre quais atividades poderiam ter sido inseridas no curso para o desenvolvimento da oralidade, serão traçadas categorias, que neste trabalho são vistas como as necessidades para se avançar no processo de formação de professores de LE no contexto EaD.

\subsubsection{Encontros presenciais}

Durante as entrevistas, quando os participantes foram questionados sobre práticas que poderiam ajudar a desenvolver ou praticar a oralidade, grande parte deles apontou encontros presenciais como uma possibilidade. 
[16] Colocar uma vez na semana, num sábado, alguma coisa assim para só trabalhar a oralidade. Eu acho que ajudaria muito, porque realmente tem essa falta. (Marta $-2^{\circ}$ semestre)

[17] De repente nos dias que tivesse prova a gente tivesse algumas aulas presenciais, mas voluntárias, para quem quisesse participar. (Jéssica $-2^{\circ}$ semestre)

Os excertos acima demonstram essa necessidade de encontros presenciais, mas o comentário da estudante Jéssica merece destaque. A estudante afirma que encontros presenciais seriam importantes e essenciais para desenvolvimento da oralidade no curso, mas na sequência afirma que esses deveriam ser opcionais para os estudantes, o que leva ao questionamento: tendo em vista que a oralidade é uma habilidade pouco praticada no ambiente virtual, quais as vantagens de se colocar uma atividade de prática dessa habilidade como opcional ao estudante?

James y Garret (1991 apud BERGILLOS 2005) afirmam que no sistema educativo britânico dois de cada três alunos que cursavam disciplinas de idiomas estrangeiros decidiam abandoná-las na primeira oportunidade que tinham, dado ao caráter optativo estabelecido no currículo. Nesse sentido, atividades do tipo optativa podem não ser efetivamente positivas por dependerem de questões como gestão de tempo e estudo por parte dos estudantes, tema bastante problemático, que será discutido adiante, tendo em vista que os estudantes estão acostumados à modalidade de ensino presencial e, muitas vezes, não sabem como realizar estudos na modalidade EaD (HERMIDA \& BONFIM 2006; LEFFA 2009).

[18] Eu acredito que encontros presenciais mesmo, que fosse uma posição dos tutores, não partisse só de nós alunos. Até porque é complicado, porque tem um pessoal que mora distante, então pra gente se juntar já é mais complicado; então se tiver aquela obrigatoriedade do tutor mesmo, ou alguma coisa que imponha, aí é mais fácil de reunir o pessoal, porque vai à força mesmo. (Paula $-2^{\circ}$ semestre - destaques meus)

A opinião da Paula vai ao encontro do que foi o exposto anteriormente e nos faz pensar sobre os papéis necessários dos agentes no processo de ensino-aprendizagem na modalidade EaD.

Levando em consideração que os estudantes já realizam alguns encontros presenciais, para realização das provas presenciais, inserir encontros presenciais para exposição e prática da LE estudada parece ser uma alternativa. Inclusive o estudante Carlos, do sétimo semestre, afirma no excerto 11 (trazido novamente a seguir) que houve durante o curso algumas oficinas e que com elas era possível treinar a língua. 
[19] a oralidade foi praticamente nula durante todo o nosso curso, eu não lembro de, com exceção de oficinas perdidas de 3 ou 4 horas que aconteceram acho que 4 vezes no curso inteiro - manhãs, a cada semestre uma manhã - em que se podia de fato ter contato com um professor real para praticar a língua, e aí, sim, praticar a oralidade e a escuta, por meio da EaD isso nunca aconteceu, então os pouquíssimos momentos de oralidade que aconteceram foram exclusivamente presenciais, que, pela natureza da $\mathrm{EaD}$, quase não existem; então pelo ambiente virtual a oralidade não foi praticada; e eu acho que não vá ser daqui até o final do curso.

Essa prática se apoia em Dõrnyei (1990 apud MICHELON 2003 p. 05), que sugere o contato com a língua ao afirmar que "a aprendizagem está, no mínimo, parcialmente incorporada ao meio onde a língua-alvo é falada, ou seja, seu domínio se dá através da exposição direta à língua ou pela instrução formal acompanhada da interação frequente com a comunidade linguística alvo."

Os encontros presenciais se apresentam como uma possibilidade real para prática da língua a ser aprendida, mas, no caso em análise, os estudantes apontam que esses encontros, que se davam em forma de oficinas, já não acontecem mais, inclusive, nenhum aluno do segundo semestre trouxe informações sobre encontros para treinar a língua, apenas se limitaram a dizer que não há encontros fora o das provas presenciais, apontando então falta desses encontros como uma possibilidade para melhorar o processo de aprendizagem da LE estudada.

\subsubsection{Papel dos agentes da EaD}

Nesse processo de refletir sobre as necessidades no contexto de aprendizagem por meio da EaD, não se pode deixar de lado o papel dos agentes desse processo. O comentário a seguir da estudante Luana, assim como o excerto 18, em que a aluna Paula afirma que os encontros presenciais deveriam ser organizados pelos tutores, nos faz levantar o papel dos professores, tutores e alunos no contexto da EaD.

[20] Se na primeira disciplina tivessem dado uma aula presencial ou tivessem enviado um vídeo pra gente como se pronunciam as letras, era bem mais fácil, mas colocaram um áudio bem difícil, não dava pra aprender direito. Acho que a presença do professor, pelo menos uma vez no semestre inteiro, é muito importante, se continuar desse jeito vai ser muito difícil chegar ao final do curso falando bem espanhol. (Luana $-2^{\circ}$ semestre) 
No caso da figura do professor, a sua ausência é notada com frequência no contexto de $\mathrm{EaD}$, tendo em vista que nessa estrutura de curso o tutor se torna o vínculo mais forte do aluno com o conteúdo e com o curso. O PPC do curso destina um tópico para os papéis desses agentes. Nesse documento o tutor é apresentado como "um elemento fundamental na EaD, pois transmite um sentimento de relação pessoal entre o aluno e a instituição, com a característica de orientação de estudos, de organização das atividades individuais e grupais, de incentivo ao prazer das descobertas". Para isso, o trabalho da tutoria é orientado "pelos professores formadores, por um orientador pedagógico, coordenado pelo coordenador do Pólo e pelo coordenador de curso" (p. 41).

Dessa forma, quando o tutor cumpre o seu papel e participa do processo de ensinoaprendizagem, o estudante se sente motivado e consegue sanar dúvidas com maior confiança. No caso do curso em análise, há também a figura de um tutor presencial, que dá apoio no polo onde acontecem as provas presenciais. O tutor do polo estudado nesta pesquisa é visto como peçachave para o sucesso dos estudantes, mais importante inclusive que os tutores das disciplinas.

[21] O tutor presencial sempre se ocupou de estimular o nosso aprendizado nos acompanhando em nossas dificuldades. Tem muitos tutores de diversas disciplinas que jamais entraram em contato para responder questionamentos ou resolver alguma dificuldade. Se se deve pensar em reduzir custos penso que eles também deveriam estar incluídos em essa possibilidade.

O excerto acima foi extraído de mensagens trocadas entre os estudantes e a coordenação do curso na plataforma virtual de aprendizagem. Havia a informação de que o tutor presencial seria tirado do polo. Os estudantes então se reuniram em apoio ao tutor, mostrando a importância do seu papel para aprendizagem dos estudantes no curso. Anterior a isso, os estudantes, durante as entrevistas, mencionaram esse mesmo tutor como ferramenta importante para a possibilidade de praticar a oralidade.

[22] e a gente tem o tutor também, ele fala super bem, então nos ajuda muito. (Paula $-2^{\circ}$ semestre)

Apesar de o tutor presencial poder ser uma ferramenta para prática da oralidade, a falta de atividades específicas no contexto presencial inviabilizam essa prática de uma forma constante. Os momentos presenciais com esse tutor estão restritos à realização das provas presenciais. 
A reflexão que trago aqui é sobre como os agentes da $\mathrm{EaD}$ podem ter um papel importante no processo de formação no contexto da EaD, independente do curso em questão. Professor e tutores ativos no processo, combinados a um estudante autônomo (tema a ser tratado a seguir), que buscam juntos o processo de construção do conhecimento, em uma aprendizagem colaborativa.

É muito importante que o professor/tutor instigue a aprendizagem colaborativa aos alunos da educação a distância, pois permite uma quebra de barreiras estabelecida pelo tempo e espaço, promovendo, desta forma, a interação e comunicação entre os alunos. ( CARNEIRO, D. 2013, p. 45)

\section{Autonomia do estudante}

É necessário problematizar a condição de agente dos estudantes nesse processo de ensino-aprendizagem no contexto da $\mathrm{EaD}$. Noto que os estudantes possuem pouca autonomia para pesquisar, ir além das atividades obrigatórias; estes estão buscando respostas prontas, com dificuldades para gerenciar seu tempo e os materiais disponíveis, como podemos notar no comentário a seguir.

[23] não tem muita coisa que faça com que a gente aprenda, a gente tem que praticamente se virar sozinho. (Luana $-2^{\circ}$ semestre)

A estudante Luana, ao utiliza a frase "fazer com que a gente aprenda", nos demonstra a postura passiva do aluno diante da aprendizagem. Essa aluna enseja que seja transmitida a ela a aprendizagem, e não se vê como agente ativo do processo de construção do conhecimento.

Dessa forma, é necessário problematizar que nem todas as deficiências relativas à falta de oralidade dos estudantes sejam apontadas como falha na organização ou estrutura do curso. A perspectiva de cursos EaD no contexto atual é apontar caminhos para a construção do conhecimento, e não somente apresentar atividades prontas (CARNEIRO, M. 2013). O comentário da estudante Paula, a seguir, nos mostra a visão que os estudantes têm acerca da construção de conhecimento no contexto da EaD.

[24] Como é EaD a gente não tem o contato. É diferente, a gente assiste a um vídeo, mas não é a mesma coisa de estar em sala de aula, com o professor falando o tempo inteiro em espanhol, então a gente fica "essa pronúncia está correta?! É dessa forma mesmo?” (Paula $-2^{\circ}$ semestre) 
É possível identificar na fala da estudante a dependência que se tem da figura do professor. Essa postura é muito comum no contexto do ensino presencial e os alunos a trazem para o contexto da EaD.

Ter dúvidas e saná-las durante o processo de ensino-aprendizagem faz parte para uma resposta positiva no contexto da EaD. No entanto, é fundamental destacar que a $\mathrm{EaD}$ demanda uma responsabilidade maior do aluno, o qual deve redobrar seus esforços para alcançar um nível significativo de aprendizagem (HERMIDA \& BONFIM 2006). Dessa forma, há que se ponderar que, muitas vezes, o aprendiz não cumpre o seu papel de agente no processo de aprendizagem. No entanto, considero relevante destacar que a equipe (tutores, professores etc.) pode ajudar o aluno a desenvolver a autonomia necessária, já que, por tradição do presencial, a maioria não chega autônomo o suficiente para seguir a proposta do curso em EaD.

\subsubsection{Recursos dentro do ambiente virtual}

Uma outra possibilidade apontada pelos estudantes para se melhorar o processo de ensino-aprendizagem de LE no contexto de EaD é o trabalho com diferentes recursos dentro da plataforma virtual de aprendizagem. Os excertos a seguir nos mostram isso:

[25] eu acredito que uma das formas, inclusive a única [para aprender], seja através de vídeos e áudios, e seria importante que tivesse o feedback do áudio que a gente mandasse. (Vanessa $-2^{\circ}$ semestre)

[26] Acho que eles poderiam, por exemplo, ter proposto atividades em que o aluno pudesse gravar, sugeririam um tema, ou alguma coisa, dentro, claro, de uma organização, uma sistematização onde o aluno gravasse com o celular, alguma coisa, e enviasse esse arquivo e a gente tivesse um feedback sobre todos os aspectos, não só de fonética empregada, mas também léxico e coisas do tipo. (Carlos $-7^{\circ}$ semestre)

A possibilidade apontada pelos estudantes é relativa a atividades dentro da plataforma virtual, uso de vídeo-aulas, atividades de gravação de áudio com feedback detalhado. Do ponto de vista estrutural, a plataforma utilizada no curso (Moodle), de acordo com Sabbatini (2007), permite funções interativas como fóruns, chats, diários; além de contar com as seguintes ferramentas para conteúdo instrucional: páginas simples de textos, páginas em HTML, acesso a arquivos em qualquer formato (PDF, DOC, PPT, Flash, áudio, vídeo, etc.) ou a links externos (URLs), acesso a diretórios (pastas de arquivos no servidor), lições interativas, livros eletrônicos, 
Wikis (textos colaborativos), glossários, perguntas frequentes. Além dessas funções, que são consideradas "padrão" no sistema Moodle, por ser a ferramenta um software livre, pode fazer muito mais; isso vai depender da demanda de cada contexto, considerando que uma equipe técnica qualificada para o desenvolvimento e manutenção da plataforma virtual pode adicionar funcionalidades a ela.

Dessa forma, estruturalmente o curso poderia fazer uso de várias ferramentas para promover interação e aprendizagem, no entanto, em praticamente todas as disciplinas, os recursos utilizados, de forma geral, eram sempre os mesmos: fóruns, chats e acesso a arquivos de textos.

Nesse contexto, retomo o que foi dito por Crawford 2008, citado por Leffa 2009 p. 156, sobre o computador e seu uso. De acordo com o autor, "uma coisa que o computador faz melhor do que qualquer outra é a interatividade. $\mathrm{Na}$ verdade, o computador não apenas faz melhor; o computador é a única mídia capaz de fornecer interatividade." Com base nessa informação, é necessário pensar nas diferentes possibilidades que o computador, a Internet e as diferentes ferramentas nesse processo podem oferecer. A ideia é que não haja a simples transposição dos textos e materiais do ensino presencial para o ensino à distância.

Para trabalhar num contexto de EaD, Leffa (2009) afirma que é necessário ser interativo, mas isso significa que é preciso aprender a fazer mais com menos texto. No entanto, isso não significa necessariamente substituir texto por gráficos, áudio e vídeo. Uma possibilidade, apresentada pelo autor, é substituir gradativamente os textos mais longos, usados nas atividades de auto-estudo, por textos mais curtos, às vezes do comprimento de uma frase; unindo a isso atividades como ler e clicar, recebendo feedback automático à medida que se avança na atividade, como se estivesse seguindo uma trilha.

Dessa forma, falta pensar em atividades mais interativas, explorando a capacidade da ferramenta tecnológica. Atividades como a realizada na disciplina de Língua Espanhola II, em que os estudantes faziam gravações sobre um determinado tema e a professora dava feedbacks orais individuais e detalhados contribuem para o processo de aprendizagem de LE e prática da oralidade e deveriam ser uma constante nesse tipo de curso, conforme podemos comprovar com o excerto a seguir.

[27] é uma ótima oportunidade para você treinar, até porque ela manda um áudio de volta comentando como foi o seu desempenho, o que você precisa corrigir, a pronúncia como está; então o feedback também é muito importante que ela manda. (Vanessa $-2^{\circ}$ semestre) 


\section{CAPÍTULO 5}

\section{CONCLUSÃO}

"El desafio que tenemos por delante parece ser ¿cómo avanzar en la enseñanza y aprendizaje de LE y adecuar los procedimientos a las innovaciones actuales de forma a superar al menos algunas de las dificultades más frecuentes? Parece claro que la respuesta estriba en conocer y aprovechar las diferentes contribuciones teóricas y prácticas que están a nuestra disposición." ${ }^{\text {36 }}$

(ERES FERNÁNDEZ \& MACIEL 2007, p. 430)

Nesta última parte, retomo as perguntas de pesquisa e busco respondê-las com base nas análises de dados realizadas no capítulo anterior. Na sequência faço algumas sugestões sobre possíveis contribuições deste estudo, assim como as limitações e as sugestões de temas para pesquisas posteriores, além de encaminhamentos pedagógicos e considerações finais.

\subsection{RETOMANDO AS PERGUNTAS DE PESQUISA}

Iniciei este trabalho buscando responder à pergunta inicial: "a modalidade a distância, na forma como está praticada na situação de pesquisa, atende de que forma à prática da oralidade no ensino de LE (espanhol)?" Para a resolução dessa pergunta iniciei a pesquisa buscando entender o que os estudantes buscam no curso de LE em análise e mapeando as habilidades e percepções deles no contexto de aprendizagem e prática da oralidade na $\mathrm{EaD}$, principalmente na condição de futuros professores de LE.

A partir dessas análises é que pude responder às perguntas específicas de pesquisa, expostas a seguir:

- Quais características predominam no curso EaD (espanhol) no que se refere ao trabalho com a oralidade do idioma?

Os estudantes ingressam no curso de licenciatura em LE sem o conhecimento da língua da qual se tornarão professores. Esses estudantes vivem um contexto de aprender para ensinar.

\footnotetext{
36 "O desafio que temos pela frente parece ser: como avançar no ensino e aprendizagem de LE e adequar os procedimentos às inovações atuais de forma a superar ao menos algumas das dificuldades mais frequentes? Parece claro que a resposta se apoia em conhecer e aproveitar as diferentes contribuições teóricas e práticas que estão a nossa disposição.” (ERES FERNÁNDEZ \& MACIEL 2007, p. 430)
} 
Levando em consideração esse contexto, a forma como os cursos de licenciatura em LE devem ser estruturados é visando a uma aprendizagem efetiva da LE, incluindo atividades que envolvam as quatro habilidades linguísticas. Essa informação se confirma quando observamos as teorias atuais sobre ensinar línguas, em que a competência comunicativa é colocada em posição de destaque, pois essa competência se relaciona ao domínio das quatro habilidades e a como usar o conjunto de conhecimentos que se possui para que essas habilidades interajam assertivamente em um contexto sociocultural determinado (ERES FERNÁNDEZ \& MACIEL 2007).

Apesar disso, no caso em análise, o que se pode notar como característica latente é o "discurso", por meio dos documentos como PPC e ementas das disciplinas, de ser capaz de estimular o estudante a aprender as quatro habilidades em língua espanhola. Apesar desse discurso, do ponto de vista prático, o que se vê é o foco apenas nas habilidades escritas (leitura e escrita). O centro do aprendizado está em regras, com provas e atividades estruturalistas. As atividades de prática oral não são contempladas. A única proposta de atividade de prática da oralidade na realidade tratava-se de um trabalho de pesquisa de uma professora.

Mesmo com a grande quantidade de atividades que poderiam ser praticadas para valorizar a oralidade, como diálogos ou conversações, entrevistas, exposições de temas, debates, conversações telefónicas e mensagens a serem gravadas (PINILLA GÓMEZ 2005), nenhuma dessas atividades ou suas variantes foram detectadas durante a presente pesquisa.

No entanto, há um esforço por parte dos agentes do curso, como o tutor presencial, para ajudar os estudantes no processo. Apesar da ausência de atividades específicas, o curso possui um material interessante e, durante o decorrer dos semestres, os estudantes conseguem ver uma melhora no seu conhecimento da língua espanhola e, como consequência, da sua capacidade de se expressar em língua espanhola, mas ainda há insegurança e ideais de se realizar um curso presencial para um pleno desenvolvimento da habilidade oral em língua espanhola.

\section{- Como o trabalho com a oralidade é visto pelos alunos do curso?}

Os estudantes confirmam a informação anterior e afirmam que não houve ou há atividades dentro do curso que contemplem esse aspecto, sendo, portanto, como afirma um estudante, "uma habilidade totalmente ignorada". Por conta desse contexto, os estudantes, independente do semestre, ainda se percebem em um nível abaixo do esperado, com dificuldades de se expressar, impactando em sua identidade de professor. 
Eles revelaram que sentem medo de se expressar oralmente, com exceção daqueles que já chegaram ao curso com domínio da língua. No entanto, há que se destacar que esses estudantes ainda possuem uma postura passiva no processo, ou seja, muitos ainda esperam por um conhecimento pronto.

\section{- Quais práticas podem ser inseridas nesse tipo de curso visando melhorias no contexto da oralidade no ensino de LE por meio da EaD?}

Por meio das entrevistas com os estudantes foi possível coletar informações e apresentar possíveis sugestões de atividades e recursos para se trabalhar a oralidade no contexto de ensino de LE na EaD. Encontros presenciais foi um tema muito abordado pelos estudantes como possibilidade de praticar a oralidade, no entanto, ainda que esse tipo de atividade tenha uma função importante e seja capaz de ajudar a trabalhar a oralidade, esse pedido dos estudantes ainda está vinculado ao contexto do ensino presencial, com a necessidade da figura do professor presente e central no processo de aprendizagem

Além de se pensar em atividades presenciais, outras propostas, como o uso de recursos na plataforma virtual, incluindo atividades de gravação e conteúdos em forma de vídeos e áudios, foram levantadas pelos estudantes. Por fim, é também necessário se pensar em um desenho de curso mais voltado para uma construção colaborativa do conhecimento, pensando no desenvolvimento de uma postura autônoma dos estudantes.

\subsection{CONTRIBUIÇÕES DO ESTUDO}

Este estudo contribui para as reflexões sobre ensinar língua, principalmente as habilidades orais, compreensão de língua oral e produção de oral, no contexto de $\mathrm{EaD}$. As contribuições trazidas estão relacionadas ao perfil dos estudantes que ingressam nesse tipo de curso e o que buscam, além das informações sobre as características das atividades desses cursos.

Além disso, espera-se que as informações trazidas contribuam para o tema de formação de professores, mais especificamente a formação de professores na região nordeste, tendo em vista que o Censo Escolar de 2012 apontou o nordeste e o norte como as regiões que possuem um número pequeno de profissionais da educação com formação superior quando comparadas as outras regiões. 


\subsection{LIMITAÇÕES DO ESTUDO}

$\mathrm{O}$ fato de a pesquisa ter se realizado em outro estado foi um aspecto limitador, pois as idas a campo para as coletas de dados precisavam de todo um processo de agendamento e organização, além de disponibilidade financeira, o que inviabilizou muitas visitas ao polo presencial. Apesar disso, a boa receptividade da instituição nos dias em que estive no polo colaborou para uma melhor e maior obtenção dos dados.

Outro fator limitador foi o semestre em que os dados foram coletados. Infelizmente no semestre de coleta o curso não contava com uma turma de calouros e outra de formandos. Dessa forma, os estudantes mais novos estavam cursando o segundo semestre enquanto que os antigos estavam cursando o sétimo (e não o nono semestre como era desejado). Como adiar a coleta aguardando novas turmas e o avanço das atuais poderia acarretar no atraso da pesquisa, ela foi realizada com alunos disponíveis na ocasião.

Além disso, o fato de não ter previsto a entrevista de tutores e professores do curso impactou na ausência de alguns dados para contraste com os dados observados e coletados dos estudantes. $\mathrm{O}$ cruzamento de todas essas informações poderia ter contemplado uma visão maior e melhor de todo o processo.

\subsection{SUGESTÕES PARA FUTURAS PESQUISAS}

A formação do professor de LE por meio da $\mathrm{EaD}$ ainda é considerado algo novo, por isso é importante se pensar nas lacunas porventura surgidas no desenvolvimento desse processo, que se torna bastante efervescente. Dessa forma, pesquisas sobre atividades e recursos tecnológicos que trabalhem as quatro habilidade linguísticas no contexto da $\mathrm{EaD}$, principalmente a oralidade, são relevantes para a LA.

Além disso, o tema autonomia do estudante no processo de aprendizagem de LE no contexto da EaD também pode ser estudado, pois muito se fala sobre o papel do estudante na $\mathrm{EaD}$, mas para o caso de aprendizagem de LE, em que o estudante aprende a língua para ensinar, esse papel precisa ser melhor definido.

Por fim, pesquisas sobre o tema de ensino-aprendizagem de LE no contexto da EaD, envolvendo os outros agentes da $\mathrm{EaD}$, como tutores, professores e a equipe multidisciplinar, surge como uma possibilidade para um olhar sobre as dificuldades enfrentadas por esses agentes 
nesse processo, suscitando novas reflexões para se continuar avançando na formação de professores.

\subsection{ENCAMINHAMENTOS PEDAGÓGICOS}

Com base nas observações, dados coletados e consequentemente análises feitas nesta pesquisa, alguns encaminhamentos surgem, na intenção de levantar novas possibilidades de caminhos no processo de formação de professores de LE no contexto da EaD.

Apesar de a EaD estar em plena expansão, grande parte dos estudantes dessa modalidade de estudo não adquiriram o perfil autônomo e colaborativo que essa modalidade de ensino necessita. Isso significa que há que se pensar em estratégias e atividades em que o estudante se torne o foco do processo de aprendizagem. Ao pensar em propostas de atividades, é necessário refletir também nas inúmeras possibilidades que as NTIC trazem para esse contexto de ensino, em que o computador passa a oferecer a possibilidade de um processo interativo, o que tem relação direta em despertar a capacidade de autonomia do estudante.

Outro fator a se considerar como uma possibilidade de avanço, exatamente por ainda não termos um perfil estudantil equivalente com o que se espera na modalidade EaD, é a possibilidade de encontros presenciais para se praticar a LE estudada. Como ainda há um perfil preso ao ensino presencial, parece ser interessante a possibilidade de momentos em que a língua possa ser estudada de modo presencial, com oficinas ou simplesmente encontros em que o foco seja a LE, principalmente sob o aspecto da oralidade.

As observações trazidas por este estudo serão compartilhadas com a instituição de ensino pesquisada, com vistas a trazer uma reflexão da atual prática e suscitar possibilidades para se avançar no aspecto da oralidade em LE no contexto de EaD.

\subsection{CONSIDERAÇÕES FINAIS}

A prática da oralidade nos cursos $\mathrm{EaD}$ se mostram como um nó na formação do professor. Fundamental destacar aqui que reconheço a importância da EaD no contexto educacional brasileiro, tendo em conta que a $\mathrm{EaD}$ e o Ensino Presencial são forças complementares e não antagônicas, e que a excelência do ensino reside nas instituições educativas e em seus aprendizes, e não apenas na utilização de novas tecnologias de educação. A 
eficácia está na interatividade, no interesse e no esforço pessoal, seja no Curso Presencial ou à distância, assim como afirma Hermida e Bonfim (2006). No entanto, ouso afirmar que, no caso da $\mathrm{EaD}$, as novas tecnologias podem ser ferramentas importantes para alcançar melhores resultados no processo de ensino aprendizagem de LE.

Paiva (2013) afirma que o uso adequado da tecnologia pode beneficiar enormemente os aprendizes de línguas, e acredito na utilização desta para melhorar o processo. O que é necessário é pensar no desenvolvimento de um ambiente virtual que favoreça a prática da oralidade, buscando um "equilíbrio entre os interesses e necessidades reais dos aprendizes", assim como afirma o PPC do curso em análise.

Dessa forma, enquanto pesquisadora e professora de língua espanhola, vejo a necessidade de avançarmos na perspectiva de formação docente sob o aspecto da oralidade. Isso significa pensar em estratégias em tornar o estudante mais ativo e também prever caminhos, por meio de atividades, que desenvolvam essa habilidade tão essencial para um professor de LE. Não faz sentido um professor não saber aquilo que ensina. Por fim, retomando a epígrafe desse último bloco, o desafio que temos pela frente parece ser avançar no ensino e aprendizagem de LE e adequar os procedimentos às inovações atuais de forma a superar ao menos algumas das dificuldades mais frequentes. Para isso, é necessário conhecer e aproveitar as diferentes contribuições teóricas e práticas que estão a nossa disposição (ERES FERNÁNDEZ \& MACIEL 2007). 


\section{REFERÊNCIAS}

ABED. Censo EAD.BR: Relatório Analítico da Aprendizagem a Distância no Brasil 2012. São Paulo: IBIPEX, 2013. Disponível em:

$<$ http://www.abed.org.br/censoead/censoEAD.BR_2012_pt.pdf $>$. Acesso em: 20 dez. 2014.

. Censo EAD.BR: Relatório Analítico da Aprendizagem a Distância no Brasil 2013.

São Paulo: IBIPEX, 2014. Disponível em:

$<$ http://www.abed.org.br/censoead2013/CENSO_EAD_2013_PORTUGUES.pdf $>$. Acesso em: 10 fev. 2015.

ADLER, P. A. \& ADLER, P. Observational Techniques. In: Denzin, N. K.; Lincoln, Y. S. (Eds.). Handbook of qualitative research. London: Sage, 1994. p. 377-392.

ALMEIDA FILHO, J. C. P. de. A Abordagem orientadora da ação do professor. In: ALMEIDA FILHO, J. C. P. (Org.). Parâmetros atuais para o ensino de português língua estrangeira. Campinas, SP: Pontes, 1997. p. 13-28

. Linguística Aplicada, Ensino De Línguas \& Comunicação. São Paulo: Pontes,

2005.

. Dimensões comunicativas no ensino de línguas. 5. ed. Campinas, SP: Pontes,

2008.

ALVES, J. R. M. A história da EaD no Brasil. In: LITTO, F. M.; FORMIGA, M. Educação a Distância: o estado da arte. São Paulo: Pearson Education do Brasil. 2009.

ANDRE, M. E. D. A. Estudo de caso: seu potencial na educação. Cadernos de Pesquisa. 1984, $\mathrm{n}^{\circ} .49$, p. 51-54.

. O que é um estudo de caso qualitativo em educação? Revista da FAEEBA -

Educação e Contemporaneidade, Salvador, v. 22, n. 40, p. 95-103, 2013.

ANGROSINO, M. Etnografia e observação participante. Porto Alegre: Artmed, 2009.

ANTHONY, E. M. Approach, method, and technique. English Language Teaching Journal, v. 17, n. 2 , p. $63-67,1963$.

BIBLIOTECA DIGITAL BRASILEIRA DE TESES E DISSERTAÇÕES (BDTD). Disponível em: <http://bdtd.ibict.br/>. Acesso em: 06 mar. 2016.

BARCELOS, A. M. F. A cultura de aprender língua estrangeira (inglês) de alunos de Letras. 1995. 200 f. Dissertação (Mestrado em Linguística Aplicada) - Universidade Estadual de Campinas, Campinas, 1995. 
BARRETO, A. B. P. Lengua española II. Natal: IFRN Editora, 2012.

BELLONI, M.L. Educação a distância. Campinas, SP: Autores Associados, 2009.

BERGILLOS, F. J. L. La motivación y el aprendizaje de una L2/LE. In: SÁNCHEZ LOBATO, J.; SANTOS GARGALLO, I. (Orgs.). Vademécum para la formación de profesores. 2. ed. Madrid: SGEL, 2005. p. 305-328.

BOSSU, C. Qualidade na educação a distância no ensino superior brasileiro: prestação de contas ou melhoria. In: CIAED CONGRESSO INTERNACIONAL DE EDUCAÇÃO A DISTÂNCIA, 16, 2010, Foz do Iguaçu - Pr. Anais... . Foz do Iguaçu - PR: CIADED, 2010. p. 1 10. Disponível em: <http://www.abed.org.br/congresso2010/cd/962010010815.pdf > Acesso em: 31 jan. 2016.

CANHETTI, C. Terminologia de recursos vocais sob o ponto de vista de fonoaudiólogos e preparadores vocais. 2008. Disponível em:

<http://www.sbfa.org.br/portal/anais2008/resumos/R1175-1.pdf>. Acesso em: 16 set. 2015.

CARNEIRO, D. E. S. Aprendizagem colaborativa na educação a distância. Dissertação (Mestrado em Educação). Universidade do Oeste Paulista - Unoeste, Presidente Prudente, SP, 2013. Disponível em: <http://tede.unoeste.br/tede/tde_busca/arquivo.php?codArquivo=438>. Acesso em: 28 fev. 2016.

CARNEIRO, M. A. LDB fácil: leitura crítico-compreensiva, artigo a artigo. 21. ed. Petrópolis, RJ: Vozes, 2013.

CHIZZOTTI, A. Pesquisa qualitativa e ciências humanas e sociais. Petrópolis, RJ: Vozes, 2006.

COUTO, L. P. \& MACIEL, D. T. E. A prática oral no ensino do espanhol. In: CONGRESSO INTERNACIONAL DE PESQUISA, EDUCAÇÃO E GESTÃO. 4., 2012, Ponta Grossa. Anais do $4^{\circ}$ Congresso internacional de pesquisa, educação e gestão, 2012.

DENZIN, N. K. \& LINCOLN, Y. S. Introdução: a disciplina e a prática da pesquisa qualitativa. In: DENZIN, N. K.; LINCOLN, Y. S. (Orgs.). O planejamento da pesquisa qualitativa: teorias e abordagens. Porto Alegre: Artmed, 2006. p. 15-41.

DIAS, P. C. \& BASTOS, A. S. A epidemia do plágio: explorando o papel da motivação e autoregulação nas atitudes em relação ao plágio. Revista Internacional de Educación y

Aprendizaje, vol. 2, n. 2, 2014. Disponível em:

$<$ http://ijles.cgpublisher.com/product/pub.229/prod.46>. Acesso em: 10 fev. 2016.

DIAS, R. A. \& LEITE, L. S. Educação a Distância: da legislação ao pedagógico. Petrópolis, RJ: Vozes, 2010. 
ERES FERNÁNDEZ, G. \& MACIEL, A. (2007). La oralidad en el proceso de enseñanza y aprendizaje del español como lengua extranjera: algunas reflexiones. Linguagem \& Ensino, v. 10, n. 2, p. 415-433.

FALTIS, C. Case study methods in researching language and education. In: HORNBERGER, N.; CORSON, D. (Eds.). In: Research methods in language and education. Encyclopedia of Language and Education, v. 8. Dordrecht: Kluwer Academic Publishers, 1997. p. 145-152.

FRAUCHES, C. Educação Superior Comentada - políticas, diretrizes, legislação e normas do ensino superior. 2011. Disponível em: < http://www.abmes.org.br/abmes/noticias/detalhe/id/117> . Acesso em: 26 fev. 2016.

FERREIRA, E. P. Oralidade em língua estrangeira (inglês) como elemento legitimador do "saber" da língua inglesa: resultado do discurso midiático. Crátilo: Revista de Estudos Linguísticos e Literários, UNIPAM, vol. 5, p. 40-49, 2012. Disponível em: $<$ http://cratilo.unipam.edu.br/documents/32405/41762/oralidade.pdf >. Acesso em: 23 jan. 2016.

FREEBODY, P. Qualitative research in education: interaction and practice. London: Sage, 2003.

GARCÍA, G. R. La enseñanza de lenguas asistida por ordenador (ELAO). In: SÁNCHEZ LOBATO, J.; SANTOS GARGALLO, I. (Orgs.). Vademécum para la formación de profesores. 2. ed. Madrid: SGEL, 2005. p. 1045-1059.

GARCÍA, M. H. Internet en la enseñanza de español In: SÁNCHEZ LOBATO, J.; SANTOS GARGALLO, I. (Orgs.). Vademécum para la formación de profesores. 2. ed. Madrid: SGEL, 2005. p. 1061-1085.

GARGALLO, I. S. El análisis del errores en la interlengua del hablante no nativo. In: SÁNCHEZ LOBATO, J.; SANTOS GARGALLO, I. (Orgs.). Vademécum para la formación de profesores. 2. ed. Madrid: SGEL, 2005. p. 391-410.

GIL, A. C. Métodos e técnicas de pesquisa social. 5. ed. São Paulo: Atlas, 1999.

GILLIS, G. The Importance of Speaking Skills. 2013. Disponível em:

$<$ http://www.geraldgillis.com/importance-speaking-skills/>. Acesso em: 06 mar. 2015.

GÓMEZ, A. B. Aportaciones del análisis del discurso oral. In: SÁNCHEZ LOBATO, J.; SANTOS GARGALLO, I. (Orgs.). Vademécum para la formación de profesores. 2. ed. Madrid: SGEL, 2005. p. 219-242.

GÓMEZ, O. M. Lengua española IV. Natal: IFRN Editora, 2012.

GÜNTHER, H. Pesquisa Qualitativa Versus Pesquisa Quantitativa: Esta é a Questão?

Psicologia: Teoria e Pesquisa, Mai-Ago 2006, vol. 22, n. 2, p. 201-210. 
HAMEL, J., DUFOUR, S., FORTIN, D. Case study methods. Qualitative research methods series. Newbury Park, CA: Sage, 1993. 77p.

HERMIDA, J. F. \& BONFIM, C. R. S. A educação à distância: história, concepções e perspectivas. Revista HISTEDBR On-line, Campinas, n. especial, p.166-181, ago. 2006.

IBGE. Acesso à Internet e à Televisão e Posse de Telefone Móvel Celular para Uso Pessoal. Pesquisa Nacional por Amostra de Domicílios - 2013. Rio de Janeiro, 2015. Disponível em: < http://biblioteca.ibge.gov.br/visualizacao/livros/liv93373.pdf>. Acesso em: 18 out. 2015.

INSTITUTO FEDERAL DE EDUCAÇÃO, CIÊNCIA E TECNOLOGIA DO RIO GRANDE DO NORTE. Projeto Pedagógico do Curso Superior de Licenciatura em Letras Espanhol na modalidade a distância. 2012.

IRAGUI, J. C. El concepto de competência comunicativa. In: SÁNCHEZ LOBATO, J.; SANTOS GARGALLO, I. (Orgs.). Vademécum para la formación de profesores. 2. ed. Madrid: SGEL, 2005. p. 1061-1085.

KIPNIS, B. Educação superior a distância no Brasil: tendências e perspectivas. In: LITTO, F. M.; FORMIGA, M. Educação a Distância: o estado da arte. São Paulo: Pearson Education do Brasil. 2009. p. 209-2014

KRASHEN, S.D. Second Language Acquisition and Second Language Learning. Oxford: Pergamon, 1981.

KURTZ, F. D. Uma análise de gênero em artigos eletrônicos de Lingüística Aplicada com foco em tópicos e procedimentos de pesquisa. 2004. 135 f. Dissertação (Mestrado em Letras) Universidade Federal de Santa Maria, Santa Maria, 2004.

LEFFA, V. J. Não tem mais sesta: gestão do tempo em cursos a distância. Letras \& Letras, Uberlândia. jul./dez. 2009. p. 145-162.

. A aprendizagem de línguas mediada por computador. In: LEFFA, V. J. (Org.).

Pesquisa em lingüística Aplicada: temas e métodos. Pelotas: Educat, 2006, p. 11-36.

. Metodologia do ensino de línguas. In BOHN, H. I.; VANDRESEN, P.

Tópicos em linguística aplicada: O ensino de línguas estrangeiras. Florianópolis: Ed. da UFSC, 1988. p. 211-236.

LITTO, F. M. O atual cenário internacional da EaD. In: LITTO, F. M.; FORMIGA, M. Educação a Distância: o estado da arte. São Paulo: Pearson Education do Brasil. 2009.

MARÍN, F. A. M. Aportaciones de la linguística aplicada. In: SÁNCHEZ LOBATO, J.; SANTOS GARGALLO, I. (Orgs.). Vademécum para la formación de profesores. 2. ed. Madrid: SGEL, 2005. p. 25-41. 
MARTÍNEZ, T. B. La evaluación de la expresión oral y de la comprensión auditiva. In: SÁNCHEZ LOBATO, J.; SANTOS GARGALLO, I. (Orgs.). Vademécum para la formación de profesores. 2. ed. Madrid: SGEL, 2005. p. 983-1003.

MENDES, R. S. A entonação no processo de ensino-aprendizagem de PLE: proposta didática para o ensino de modelos de entonação interrogativa do português do Brasil estado de São Paulo. Dissertação de Mestrado, Universidade de Brasília. Brasília: 2013.

MICHELON, D. A motivação na aprendizagem da língua inglesa. Revista Língua e Literatura. vol. 5, n. 8/9, 2003. Disponível em:

$<$ http://revistas.fw.uri.br/index.php/revistalinguaeliteratura/article/view/33>. Acesso em: 20 jan. 2016.

MINISTÉRIO DA EDUCAÇÃO. Instituições de Educação Superior e Cursos Cadastrados. Disponível em: <http://emec.mec.gov.br/>. Acesso em: 26 fev. 2016.

MOITA LOPES, L. P. Pesquisa interpretativista em Linguística Aplicada: a linguagem como condição e solução. Delta, São Paulo, vol. 10, n. 2, 329-338, 1994.

MORAN, M. J. O que é educação a distância. Rio de Janeiro, 2002. Disponível em: $<$ http://www2.eca.usp.br/moran/wp-content/uploads/2013/12/dist.pdf > . Acesso em: 09 mar. 2015.

MORAN, M. J. et al. Novas tecnologias e mediação pedagógica. Campinas, SP: Papirus. 2000.

MORAN, M. J. et al. Novas tecnologias e mediação pedagógica. 21. ed. rev. e atual. Campinas, SP: Papirus. 2013.

MOREIRA, H.; CALEFFE, L. G. Metodologia de pesquisa para o professor pesquisador. Rio de Janeiro: DP\&A, 2006.

MOURA FILHO, A. C. L. Reinventando a aula: Por um contexto cooperativo para a aprendizagem de inglês como língua estrangeira. Brasília, 2000, 161 p. Dissertação (Mestrado em Linguística) - Departamento de Linguística, Língua Clássica e Vernácula, Universidade de Brasília, 2000.

MOURA FILHO, A. C. L. Pelo inglês afora: carreira profissional e autonomia na aprendizagem de inglês como língua estrangeira. Brasília, 2005, 281p. Tese (Doutorado em Linguística Aplicada). Faculdade de Letras, Universidade Federal de Minas Gerais, 2005.

NUNES, I. B. A história da EaD no mundo. In: LITTO, F. M.; FORMIGA, M. Educação a Distância: o estado da arte. São Paulo: Pearson Education do Brasil. 2009. 
OLIVEIRA, E. C. de. Navegar é preciso. In: PEREIRA, A. L.; GOTTHEIM. L. (Orgs).

Materiais didáticos para o ensino de Língua Estrangeira. Campinas: Mercado de Letras, 2013.

PAIVA, V. L. M. O. O uso da tecnologia no ensino de línguas estrangeiras: breve retrospectiva histórica. In: JESUS, Dánie Marcelo de; MACIEL. Ruberval Franco (Orgs.) Olhares sobre tecnologias digitais: linguagens, ensino, formação e prática docente. Coleção: Novas Perspectivas em Linguística Aplicada Vol. 44. Campinas, SP: Pontes Editores, 2015, p.21-34.

.A formação do professor para uso da tecnologia. In: SILVA, K.. A.; DANIEL, F. G.; KANEKO-MARQUES, S. M.; SALOMÃO, A. C. B. (Orgs.) A formação de professores de línguas: Novos Olhares - Volume 2. Campinas, SP: Pontes Editores, 2013. p. 209-230.

. A www e o ensino de Inglês. Revista Brasileira de Linguística Aplicada, v.1, n.

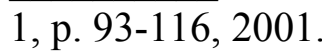

PINILLA GÓMEZ, R. La expresión oral. In: SÁNCHEZ LOBATO, J.; SANTOS GARGALLO, I. (Orgs.). Vademécum para la formación de profesores. 2. ed. Madrid: SGEL, 2005. p. 879897.

PLATERO, L. Discutindo habilidades, construindo competências: compreensão e produção oral. 2002. Disponível em: < http://www.sbs.com.br/e-talks/trabalhando-habilidadesconstruindo-competencias-compreensao-e-producao-oral/>. Acesso em: 10 mar. 2015.

POLESEL FILHO, P. A Comunicação Mediada pelo Computador: diferentes formas de contato e aprendizagem. In: XXIV CONGRESSO BRASILEIRO DA COMUNICAÇÃO, Campo Grande, 2001.

PRETTO, J. R. Competência comunicativa: importância e impacto no ensino de línguas estrangeiras. P@rtes. Dezembro de 2010. Disponível em:

$<$ www.partes.com.br/educacao/competenciacomunicativa.asp>. Acesso em 23 jan. 2016

ROSA, M. V. F. P. C. \& ARNOLDI, M. A. G. C. A entrevista na pesquisa qualitativa: mecanismos para validação dos resultados. Belo Horizonte: Autêntica, 2006.

SABBATINI, R. M. E. Ambiente de ensino e aprendizagem via internet: A Plataforma Moodle. Edumed. (2007) Disponível em:

$<$ http://www.ead.edumed.org.br/file.php/1/PlataformaMoodle.pdf $>$. Acesso em: 15 fev. 2016.

SANTOS, K. F. Experimentação em TICS: reflexões para a prática da oralidade no ensino de L.E. em ambiente virtual de aprendizagem (AVA). Dissertação de Mestrado, Universidade de Brasília. Brasília: 2013.

SILVA, O. S. F. Entre o plágio e a autoria: qual o papel da universidade? Revista Brasileira de Educação, v. 13, n. 38, p. 357-368, 2008. 
STAKE, R. E. Case studies. In: Denzin, N. K. \& Lincoln, Y. S. (Eds.). Handbook of qualitative research. London: Sage, 1994. p. 236-247.

VILAÇA, M. L. C. Métodos de Ensino de Línguas Estrangeiras: fundamentos, críticas e ecletismo. Revista Eletrônica do Instituto de Humanidades da UNIGRANRIO/UFF, Volume VII, número XXVI, Jul-Set., 2008. 


\section{APÊNDICES}

\section{APÊNDICE I}

\section{TERMO DE SOLICITAÇÃO DE ACESSO PARA PESQUISA}

Eu, Luciana Brandão Dourado, CPF XXXXX, aluna regular do Programa de PósGraduação em Linguística Aplicada (PGLA) da Universidade de Brasília (UnB), inscrita na matrícula 14/0014004, venho, por meio deste, solicitar junto XXXXX, especificamente ao curso de Licenciatura em Letras Espanhol, autorização para a realização de minha pesquisa de Mestrado intitulada "O Trabalho com a Oralidade em um Curso de Licenciatura em Língua Espanhol (EaD): Expectativas e Necessidades", sob orientação do Prof. Dr. Hélvio Frank de Oliveira. Mais especificamente, o acesso ao ambiente virtual nas disciplinas de língua espanhola das turmas de primeiro e último semestre durante o período acadêmico $1 \% / 2015$. Para tal, esclareço que o estudo tem como objetivo observar a aprendizagem dos alunos, futuros professores, da expressão oral no ambiente virtual. A análise será com base na navegação dentro do sistema, no acompanhamento linguístico-pedagógico das propostas curriculares e atividades produzidas, bem como das percepções e sentimentos dos alunos. Portanto, espera-se entender como se dá o processo da construção do domínio da expressão oral em língua espanhola desses futuros professores. Definidos os objetivos, a pesquisa se dará em dois momentos:

- Acompanhamento das atividades dos estudantes no ambiente virtual no período acadêmico $1^{\circ} / 2015$;

- Entrevista com alguns estudantes no dia de aula presencial no polo Natal, em datas a definir.

Esclareço ainda que questionários virtuais poderão ser utilizados e, nesse caso, todos os procedimentos para sua aplicação serão formalizados por meio do Termo de Consentimento Livre e Esclarecido, e a coordenação de curso será previamente informada da atividade de pesquisa.

Brasília, 10 de fevereiro de 2015. 


\section{APÊNDICE II \\ PERGUNTAS DOS QUESTIONÁRIOS}

\section{QUESTIONÁRIO PARA ALUNOS DO $2^{\circ}$ SEMESTRE \\ PESQUISA}

Prezados alunos da disciplina Língua Espanhola II,

Estou realizando uma pesquisa sobre a aprendizagem de língua espanhola no curso de licenciatura em língua espanhola e as suas respostas são fundamentais para esta atividade.

Obrigada por participar!

1. O que te motivou a se matricular nesse curso de licenciatura?

2. Você já realizou algum outro curso de língua estrangeira na modalidade EaD?

3. Como você classifica o seu conhecimento da língua espanhola ao ingressar no curso?

Nenhum

Pouco

Mediano

Muito

4. Como você classifica o seu conhecimento atual da língua espanhola?

Nenhum

Pouco

Mediano

Muito 
5. Qual habilidade você considera a mais importante para um professor de línguas?

Leitura

Escrita

Fala

Compreensão

6. Qual habilidade você considera a mais difícil de ser aprendida?

Leitura

Escrita

Fala

Compreensão

7. Quais atividades propostas estão sendo capazes de desenvolver a sua oralidade?

8. Quais são as suas expectativas em relação à aprendizagem da língua espanhola até o final do curso?

\section{QUESTIONÁRIO PARA ALUNOS DO 7º SEMESTRE PESQUISA}

Prezados alunos,

Estou realizando uma pesquisa sobre a aprendizagem de língua espanhola no curso de licenciatura em língua espanhola e as suas respostas são fundamentais para esta atividade.

Obrigada por participar!

1. O que te motivou a se matricular nesse curso de licenciatura? 
2. Você já realizou algum outro curso de língua estrangeira na modalidade EaD?

3. Como você classifica o seu conhecimento da língua espanhola ao ingressar no curso?

Nenhum

Pouco

Mediano

Muito

4. Como você classifica o seu conhecimento atual da língua espanhola?

Nenhum

Pouco

Mediano

Muito

5. Qual habilidade você considera a mais importante para um professor de línguas?

Leitura

Escrita

Fala

Compreensão

6. Qual habilidade você considera a mais difícil de ser aprendida?

Leitura

Escrita

Fala

Compreensão 
7. Quais atividades propostas estão sendo capazes de desenvolver a sua oralidade?

8. Quais são as suas expectativas em relação à aprendizagem da língua espanhola até o final do curso? 


\section{APÊNDICE III \\ ROTEIRO DE ENTREVISTAS}

$2^{\circ}$ Semestre

1. Qual tipo de conhecimento da língua espanhola você possuía ao ingressar no curso?

2. Quais atividades realizadas nessa disciplina ajudaram a desenvolver a sua oralidade?

3. Qual a sua opinião sobre as atividades com gravação de áudio? Você gostou de realizálas?

4. Como você classificaria hoje a sua capacidade de expressão oral em língua espanhola?

5. Quais as suas expectativas em relação à língua espanhola (principalmente na parte da oralidade) até o término do curso?

6. Há alguma sugestão de atividade que você gostaria de realizar para desenvolvimento de sua oralidade?

$7^{\circ}$ Semestre

1. Qual tipo de conhecimento da língua espanhola você possuía ao ingressar no curso?

2. Quais atividades realizadas nas disciplinas ajudaram a desenvolver a sua oralidade?

3. Como você classificaria hoje a sua capacidade de expressão oral em língua espanhola?

4. Você se sente pronto para ministrar uma aula em língua espanhola?

5. Quais as suas expectativas em relação à língua espanhola (principalmente na parte da oralidade) até o término do curso?

6. Quais os seus sentimentos em relação à capacidade de expressão em língua espanhola?

7. Há alguma sugestão de atividade que você gostaria de ter realizado para desenvolvimento de sua oralidade? 


\section{APÊNDICE IV \\ ENTREVISTAS DEGRAVADAS ${ }^{37}$}

$2^{\circ}$ Semestre

\section{Marta}

1. Qual tipo de conhecimento da língua espanhola você possuía ao ingressar no curso?

Eu já fiz curso de espanhol, mas foi pouco, assim, foram 6 meses. Escolhi [a licenciatura em espanhol] porque sempre gostei, desde pequena a língua espanhola sempre me agradou... eu via muita novela mexicana e essas coisas. Eu gostava de sempre ver em espanhol; e eu sou apaixonada pelo México, acho lindo e sempre pesquisei tudo que era relacionado [a língua espanhola]. Eu odeio inglês, já fiz inglês umas dez vezes, mas não "vai", então eu "puxo" pelo espanhol mesmo.

2. Quais atividades realizadas nessa disciplina ajudaram a desenvolver a sua oralidade?

Realmente não tem, isso eu até coloquei, eu acho que um ponto falho seria esse. Até agora na [disciplina] língua espanhola II, até se desenvolveu algumas atividades que é pra você gravar; é você fazer um texto e gravar para mandar para ver como está a oralidade e tal, mas é uma coisa que vem a falhar é isso; porque é complicado.

3. Qual a sua opinião sobre as atividades com gravação de áudio? Você gostou de realizálas?

Eu gostei, achei bem melhor; porque é uma coisa que falta realmente, porque é diferente de você estar num curso onde você está falando e tá "puxando" a sua fala toda hora, e como a EAD é mais pra isso, pra quem trabalha como eu trabalho, pra quem já faz outra faculdade que nem eu faço; então fica complicado, realmente você aprende a escrever e a ler, mas a falar fica complicada.

Eu ainda não vi feedback [da atividade oral], mas creio que ela deu, ela sempre corrige e coloca.

\footnotetext{
${ }^{37}$ Nomes fictícios foram adotados para preservar a identidade dos participantes.
} 
4. Como você classificaria hoje a sua capacidade de expressão oral em língua espanhola? Mais ou menos. Hoje não me sinto preparada para dar aula.

5. Quais as suas expectativas em relação à língua espanhola (principalmente na parte da oralidade) até o término do curso?

$\mathrm{Eu}$ espero que tenha um melhoramento nessa parte, que tenham mais atividades que envolvam [a prática oral]. Assim, fica complicado que muita gente é do interior, mas eu acharia super válido colocar uma vez na semana, num sábado, alguma coisa assim para só trabalhar a oralidade. Eu acho que ajudaria muito, porque realmente tem essa falta. Agora eu pretendo pelo menos sair bem na escrita e na leitura, e oralidade eu creio que tenho que fazer um curso depois, por fora, pra pegar a questão da oralidade.

6. Há alguma sugestão de atividade que você gostaria de realizar para desenvolvimento de sua oralidade?

O tutor fala em espanhol, isso ajuda, mas é complicado pra gente.

Acho que tem que fazer o curso [curso de língua], não é só ficar com esse aqui, porque a modalidade à distância é complicada, eu já fiz outro curso à distância e é complicado porque, primeiro você não está ali o tempo todo, não tem como pedir ajuda o tempo todo, e a questão da fala mesmo, é bem complicado, ainda mais de língua; um [curso] normal já é complicado.

\section{Luana}

1. Qual tipo de conhecimento da língua espanhola você possuía ao ingressar no curso?

Eu tive aula de espanhol no ensino médio, estudei em uma escola que tinha espanhol, disciplina. Eu morei dois anos em uma cidade aqui no Rio Grande do Norte onde a rotatividade de turistas argentinos, pessoas que falam a língua espanhola, seja na América do Sul ou na Europa, muito grande; convivi, trabalhei com muitas pessoas, muitos argentinos, e assim, como eu já tinha um pouco de noção do espanhol da escola, e conversando com eles, vivendo com eles, vivenciando a todo momento, então assim, pra mim não tem dificuldade. Essa é a experiência que eu tive antes de entrar no curso. 
2. Quais atividades realizadas nessa disciplina ajudaram a desenvolver a sua oralidade?

Esse semestre tivemos algumas atividades, nós enviávamos áudio para as professoras, mas no semestre passado não. Eu não tinha dificuldade, mas muitos colegas que nunca tinham vivenciado a língua tinham muita dificuldade porque de cara já colocaram disciplina que era tudo em espanhol, então você tinha que escrever, tinha que ler... ler é fácil, compreender é fácil porque é um pouco parecido com nossa língua, mas escrever já é mais complicado, quem não tinha experiência nenhuma eu acho que ficou perdido, tinha dificuldade. E mesmo tendo "pagado" a língua espanhola I tem muita dificuldade na oralidade agora porque se você não for buscar, não for por você mesmo aprender, mesmo ouvindo música ou lendo, ou vendo vídeo, assistindo novela, seja lá o que for, não tem muita coisa que faça com que a gente aprenda, a gente tem que praticamente se virar sozinho e foi cobrado esse semestre que nós enviássemos áudios para os professores.

3. Qual a sua opinião sobre as atividades com gravação de áudio? Você gostou de realizálas?

Não gostei, porque eu tenho muita insegurança de falar. Tenho muita insegurança porque eu sei as coisas, mas como eu vejo em televisão, eu vejo em tudo, mas eu não tenho como fazer isso sem o professor me orientando. A gente não tem essa orientação na disciplina.

4. Como você classificaria hoje a sua capacidade de expressão oral em língua espanhola?

Eu acho que o que me prejudica mais é a vergonha, a timidez, mas eu acho que eu falo bem sim. Quando eu estou em casa eu colo músicas, eu canto, falo bem sim, consigo conversar com algumas pessoas, mas, digamos assim, numa avaliação eu tenho um pouco de vergonha.

5. Quais as suas expectativas em relação à língua espanhola (principalmente na parte da oralidade) até o término do curso?

Como eu busco aprender sozinha, eu acho que futuramente eu vou ter um pouquinho mais de segurança, mas vem de mim, porque se continuar dessa forma assim que nunca mandam uma vídeo-aula, vai ser difícil. Se continuar dessa mesma forma até o final vai ser difícil; sei lá, uma aula presencial, uma vez na vida, pra tirar dúvida, até mesmo se na primeira disciplina tivessem dado uma aula presencial ou tivessem enviado um vídeo pra gente como se pronunciam 
as letras, era bem mais fácil, mas colocaram um áudio bem difícil, não dava pra aprender direito. Acho que a presença do professor, pelo menos uma vez no semestre inteiro é muito importante, se continuar desse jeito vai ser muito difícil chegar ao final do curso falando bem espanhol.

\section{Vanessa}

1. Qual tipo de conhecimento da língua espanhola você possuía ao ingressar no curso?

Eu fiz o curso de idiomas antes de vir [cursar a graduação]. Foram 2 anos e meio. Na verdade o curso era de 3 anos, só que na metade do último semestre eu comecei a trabalhar e os horários não estavam coincidindo e eu tive que sair. Aí, digamos, eu fiquei até o nível 5 e eram 6 níveis.

2. Quais atividades realizadas nessa disciplina ajudaram a desenvolver a sua oralidade?

Não vejo muita preocupação com a oralidade, e acredito que quem não tem um conhecimento tem uma dificuldade enorme, porque, por exemplo, no segundo semestre nós já estudamos fonética e fonologia e todo o material é em espanhol, então, assim, já é algo complicado de você aprender; quando você não tem conhecimento da língua, você ler todo o material de uma disciplina complicada em espanhol, assim, eu que conheço tive dificuldade, imagine quem só "pagou” espanhol I no semestre anterior e, assim, é um espanhol bem básico que a gente "paga" no primeiro semestre.

Assim, eu tive mais dificuldade também porque já fazia 2 anos que eu tinha terminado o curso, e a prática não é constante no meu dia a dia; porque não tem muito com quem você falar; então já tive essa dificuldade sendo que já tive contato. Quem não tem esse conhecimento acredito que teve uma dificuldade enorme, e eu não vejo muito incentivo com a oralidade, assim, não tem vídeo-aulas... Quando era outra coordenadora, uma vez no semestre tinha uma aula com algum professor com algum tema pra gente conversar mesmo em espanhol e dava pra você ter uma prática, mesmo que fosse uma vez, mas tinha alguma coisa, e agora não teve nada; até agora não teve nada. Já faz mais ou menos um ano que está o novo coordenador e não teve nenhuma aula assim como tinha antes, com algum tema proposto, por exemplo, quando eu fui o tema era cultura. A gente falou sobre música, dos países, sobre os cantores, tudo em espanhol, e o professor ia orientando a gente como falar e isso era um incentivo maior e para quem não tem com quem praticar é muito bom. 
3. Qual a sua opinião sobre as atividades com gravação de áudio? Você gostou de realizálas?

Essa atividade não é nem da disciplina, é uma pesquisa para uma professora e a gente assinou um termo no semestre passado e ela usa a disciplina de espanhol para fazer essa pesquisa com a gente. Aí toda semana ela manda uma atividade, por exemplo, pede pra gente falar das férias, pede pra gente falar da nossa vida e a gente grava o áudio e envia para ela através da plataforma, mas não é da disciplina especificamente. Da própria disciplina teve no começo um áudio pra gente se apresentar e eu nem tenho certeza se foi de língua espanhola, acho que foi de cultura hispânica que a professora pediu que a gente gravasse um áudio se apresentando, não foi nem da disciplina de espanhol.

Tiveram quatro atividade orais, que foi exatamente para a pesquisadora, que ela está desenvolvendo a pesquisa, acho que é doutorado ou mestrado, não sei, a gente tinha assinado o termo, acho que faz dois semestres já que a gente assinou, aí ela sempre manda através da disciplina de espanhola pra gente gravar esses áudios. Inclusive ela mesma quem corrige, aí a gente ganha uma pontuação se você gravar os quatro áudios do semestre; acho que você ganha meio ponto depois na nota geral, alguma coisa assim. Mas acho que, independente dos pontos, é uma ótima oportunidade para você treinar, até porque ela manda um áudio de volta comentando como foi o seu, o que você precisa corrigir, a pronúncia como está; então o feedback também é muito importante que ela manda.

4. Como você classificaria hoje a sua capacidade de expressão oral em língua espanhola?

Média. Porque eu passei muito tempo, acho que foi cerca de 1 ano e meio a 2 anos, sem ter um contato direto; você ouve música, mas não está ali praticando, então, por exemplo, regras de gramática e esse tipo de coisa você acaba esquecendo. Assim, eu consigo compreender quando a pessoa fala, e tenho tentado tudo que eu assistir, que eu puder colocar em espanhol eu coloco, se não dá eu tento pelo menos colocar a legenda pra ter o máximo de contato possível com a língua, porque se você não tiver fica muito difícil. 
5. Quais as suas expectativas em relação à língua espanhola (principalmente na parte da oralidade) até o término do curso?

Eu espero que tenha um foco maior na oralidade nas próximas [disciplinas] porque agora a gente vai "pagar" espanhol III, IV... que o foco seja mais na oralidade até porque acredito que agora nesse I e II a gente viu bastante regra e a gente precisa trabalhar essas regras porque senão a gente vai esquecer de novo; então acredito que a minha maior preocupação é essa falta de investimento na oralidade. Eu espero que nos próximos semestres ela seja maior e que ela aconteça de fato.

6. Há alguma sugestão de atividade que você gostaria de realizar para desenvolvimento de sua oralidade?

Eu acredito que vídeo-aulas, sejam interessantes, para você ouvir outra pessoa falando e, assim, ela escolhe um tema para ser proposto naquela vídeo-aula e pede que você envie um áudio, comentando, ou dando a sua opinião sobre o assunto, dando sugestões sobre aquele assunto, algo do tipo, porque é um curso EAD e supõe-se que as pessoas não têm tempo de vir para a aula presencial, então adianta marcar, porque até quando marca o pessoal não comparece. Sempre reclamam que não tem, mas quando tem não comparecem. Então acredito que a plataforma seja a melhor forma de trabalhar isso. Eu acredito que uma das formas, inclusive a única, seja através de vídeos e áudios, e seria importante que tivesse o feedback do áudio que a gente mandasse.

\section{Célia}

1. Qual tipo de conhecimento da língua espanhola você possuía ao ingressar no curso? Já tive contato. Estudei turismo no IFRN durante 2 anos.

2. Quais atividades realizadas nessa disciplina ajudaram a desenvolver a sua oralidade? Fonética e fonologia. 
3. Qual a sua opinião sobre as atividades com gravação de áudio? Você gostou de realizálas?

Produtiva porque a professora, com o feedback que ela dá, a gente sabe onde está errando; pede pra gente gravar novamente.

4. Como você classificaria hoje a sua capacidade de expressão oral em língua espanhola? Melhorou bastante, mas não consigo dar aula em língua espanhola.

5. Quais as suas expectativas em relação à língua espanhola (principalmente na parte da oralidade) até o término do curso?

Eu estou gostando. Na verdade é angustiante, assim, que a disciplina quando a gente não compreende, fica um pouco angustiada, mas depois que melhora eu sinto que estou avançando.

6. Há alguma sugestão de atividade que você gostaria de realizar para desenvolvimento de sua oralidade?

Bom, eu gostaria, apesar de ser a distância, que tivesse pelo menos umas 2 ou 3 aulas presenciais, onde pudéssemos praticar a oralidade com a professora, seria muito interessante.

\section{Jéssica}

1. Qual tipo de conhecimento da língua espanhola você possuía ao ingressar no curso?

Não tenho, eu sempre tive uma facilidade em ler, leio em espanhol rapidamente, mas, em compensação, na fala eu sou muito tímida, eu acho.

2. Quais atividades realizadas nessa disciplina ajudaram a desenvolver a sua oralidade?

Nesse segundo semestre, na parte da gravação, que a gente tem um feedback da professora, eu acho que foi muito importante. Eu acho que deveria ter esse exercício, de repente, em outras disciplinas. 
3. Qual a sua opinião sobre as atividades com gravação de áudio? Você gostou de realizálas?

Eu escrevi, então eu gravei lendo. Como a gente ainda não tem muita pronúncia, eu acho que a gente precisa de mais atividades que forcem um pouco a barra, a gente tem os CDs, mas se tiver uma atividade que force, até pra gente ouvir, eu acho que isso facilitaria. Tanto a gente ter a gravação nossa quanto a gente ouvir, ter mais aulas onde os professores falassem em espanhol, explicassem a parte oral.

4. Como você classificaria hoje a sua capacidade de expressão oral em língua espanhola? Não consigo manter um diálogo em língua espanhola.

5. Quais as suas expectativas em relação à língua espanhola (principalmente na parte da oralidade) até o término do curso?

Eu espero ter uma segurança maior, eu acho até que eu saberia falar; se eu ler um texto eu consigo falar, mas eu não me sinto segura em conversar com alguém, acho que pelo medo de errar, talvez eu ache feio o espanhol mal falado, eu acho que esse é o principal ponto.

6. Há alguma sugestão de atividade que você gostaria de realizar para desenvolvimento de sua oralidade?

Não tenho uma sugestão agora, mas acho que aulas presenciais no fim de semana. De repente nos dias que tivesse prova a gente tivesse algumas aulas presenciais, mas voluntárias, para quem quisesse participar.

\section{Paula}

1. Qual tipo de conhecimento da língua espanhola você possuía ao ingressar no curso?

Não, conhecimento mesmo não, só o que a gente vê, um pouco da fala [mais de ouvir], mas conhecimento de língua espanhola não. 
2. Quais atividades realizadas nessa disciplina ajudaram a desenvolver a sua oralidade?

$\mathrm{Na}$ língua espanhola I não teve isso, mas tem uma tutora agora que ela solicita que a gente faça áudios, grave áudios e envie para ela e ela dá um feedback dizendo o que está bom, o que está errando, o que precisa melhorar, e eu acho bem interessante essa parte, tá ajudando muito.

3. Qual a sua opinião sobre as atividades com gravação de áudio? Você gostou de realizálas?

Tá ajudando bastante, porque como é $\mathrm{EaD}$ a gente não tem o contato. É diferente, a gente assiste um vídeo, mas não é a mesma coisa de estar em sala de aula, com o professor falando o tempo inteiro em espanhol, então a gente fica "essa pronúncia está correta?! É dessa forma mesmo?". E vem essa questão das variantes, a gente acaba ficando com medo de falar; e a gente tem o tutor também, ele fala super bem, então ajuda muito.

4. Como você classificaria hoje a sua capacidade de expressão oral em língua espanhola? Tá melhor que no início, porque não era nada, mas eu ainda tenho medo.

5. Quais as suas expectativas em relação à língua espanhola (principalmente na parte da oralidade) até o término do curso?

Eu espero que essa dificuldade que eu estou sentindo agora, como eu não tinha contato anteriormente com o idioma, eu espero que seja natural, eu espero que seja superada porque realmente eu estou apavorada nesse bimestre. Eu estou apavorada com fonologia, com fonética, tá matando mesmo. Dificuldade de compreensão mesmo, a gente tá tendo dificuldade porque é muita informação ao mesmo tempo. A gente tem um grupo no WhatsApp e a gente fica sempre discutindo essa questão: "não entendi isso; tá complicado". Então todo mundo tá achando difícil. Eu espero que seja só coisa de marinheiro de primeira viagem, que isso melhore depois.

Todo mundo tá perdido [do grupo], principalmente em fonética e fonologia. Você olha pro material e vê assim: não, a gente não tá conseguindo. No semestre anterior o material era mais completo, nesse a gente sente que não tá satisfazendo a necessidade que a gente tem de compreender aquilo alí. 
6. Há alguma sugestão de atividade que você gostaria de realizar para desenvolvimento de sua oralidade?

$\mathrm{Eu}$ acredito que encontros presenciais mesmo, que fosse uma posição dos tutores, não partisse só de nós alunos. Até porque é complicado porque tem um pessoal que mora distante, então pra gente se juntar já é mais complicado; então se tiver aquela obrigatoriedade do tutor mesmo, ou alguma coisa que imponha, aí é mais fácil de reunir o pessoal, porque vai à força mesmo.

\section{Leila}

1. Qual tipo de conhecimento da língua espanhola você possuía ao ingressar no curso? Nenhum.

2. Quais atividades realizadas nessa disciplina ajudaram a desenvolver a sua oralidade?

A produção de vídeos [áudio]. Eles pedem que a gente faça vídeos e mande. Produza um texto e fale em espanhol, mas como tá muito cedo, acabei de começar...

3. Qual a sua opinião sobre as atividades com gravação de áudio? Você gostou de realizálas?

Eu achei legal, interessante. [Depois afirmou que escreveu o texto e leu].

4. Como você classificaria hoje a sua capacidade de expressão oral em língua espanhola?

Como é o segundo semestre, eu acho que preciso avançar bastante. Eu também percebo que à distância é mais difícil. No meu caso, eu pretendo entrar num curso presencial de língua pra poder aprimorar porque eles não disponibilizam vídeo-aula, e isso tem dificultado bastante o aprendizado da gente, e outra coisa, material esse semestre não veio impresso, então está sendo muito difícil.

Semestre passado fizeram uma vídeo aula, a gente já até reclamou com o tutor e ele vai [organizar] pra gente pra mandar pra alguém superior porque ele não pode fazer muita coisa, mas realmente tá sendo bem difícil. 
5. Quais as suas expectativas em relação à língua espanhola (principalmente na parte da oralidade) até o término do curso?

Eu sei que eu tenho que buscar outras situações porque se continuar dessa forma a gente pode até se formar, mas sem nenhuma qualidade.

[Vai procurar um curso de línguas] Por conta dessa falta de interação com o alunoprofessor e a questão do material. É muito difícil, é muita coisa para você estar ali parada, sentada na frente do computador e lendo e lendo só no computador. [Material só de texto]

6. Há alguma sugestão de atividade que você gostaria de realizar para desenvolvimento de sua oralidade?

Vídeo-aula, eu acho que conversação seria interessante. Por exemplo, hoje a gente fez a prova, bem complicada, sobre verbos. E fizemos a prova e teve o material e não teve vídeo-aula, não teve nada, então a maioria ficou com muita dúvida. Fizemos a prova, mas sinceramente...

[NOTA: A prova contém pedaço do que foi aprendido no semestre. Não houve outra prova.]

A maioria da turma não está satisfeita com a questão do material que foi disponibilizado, a questão da vídeo-aula; o tutor é muito bom, mas ele sofre com as questões, por exemplo, viemos no sábado fazer a prova e a prova não foi enviada para cá, todo mundo veio atoa. Viemos no dia de semana e muitas pessoas não puderam vir.

$7^{\circ}$ Semestre

\section{Carlos}

1. Qual tipo de conhecimento da língua espanhola você possuía ao ingressar no curso?

Quando eu entrei no curso eu já tinha terminado uns cursos livres de espanhol, eu já tinha feito DELE, então eu já tinha DELE B2. Então eu entrei com um nível relativamente bom na língua. A competência comunicativa relativamente boa.

2. Quais atividades realizadas nas disciplinas ajudaram a desenvolver a sua oralidade?

$\mathrm{Na}$ verdade, no que se refere, por exemplo, à questão fonética, quando a gente estuda dialetologia ou estuda fonética e fonologia, por exemplo, sempre é interessante, então a 
competência comunicativa ela melhora nesse sentido, além disso, quando a gente estuda dialetologia a gente estuda as zonas dialetais, então a gente sente um pouco mais conhecedor de toda essa diversidade. Então isso termina impactando positivamente também na sensação de domínio da língua.

3. Como você classificaria hoje a sua capacidade de expressão oral em língua espanhola?

Eu acho muito boa, assim, apesar de toda deficiência na possibilidade de praticar, que é uma coisa que me parece muito recorrente nos cursos à distância, o exercício das habilidades orais, inclusive de escuta, porque praticamente, na nossa realidade, não é praticado; por conta disso eu sinto que, apesar dessa deficiência, eu tenho um bom nível na língua.

Dificilmente [se não tivesse um conhecimento prévio iria desenvolver a competência oral]. E a minha sensação, baseada no contato com outros colegas do curso, que não passaram por esses conhecimentos prévios, essas possibilidades de praticar, é um nível de conhecimento muito reduzido. A gente chega ao sétimo período com alunos que quase não possuem habilidade oral ou mesmo habilidade de escuta da língua, e me parece que seria essa a minha realidade também [se não tivesse feito o curso].

4. Você se sente pronto para ministrar uma aula em língua espanhola?

Sim, me sinto bem, inclusive eu faço parte do PIBID, e as oficinas que a gente ministra são assim, todas na língua meta.

5. Quais as suas expectativas em relação à língua espanhola (principalmente na parte da oralidade) até o término do curso?

A gente tem mais dois semestres, e, baseado em tudo o que a gente já viu, na forma como o curso está organizado, eu não acho que vá existir, realmente, nenhum tipo de mudança nessa seara, eu acho que a gente vai continuar sem nenhum tipo de destaque à oralidade; esta foi praticamente nula durante todo o nosso curso, eu não lembro de, com exceção de ofícinas perdidas de 3 ou 4 horas que aconteceram acho que 4 vezes no curso inteiro - manhãs, a cada semestre uma manhã - onde se podia de fato ter contato com um professor real para praticar a língua, e aí, sim, praticar a oralidade e a escuta, por meio da EAD isso nunca aconteceu, então os pouquíssimos momentos de oralidade que aconteceram foram exclusivamente presenciais, que, 
pela natureza da EAD, quase não existem; então pelo ambiente virtual a oralidade não foi praticada; e eu acho que não vá ser daqui até o final do curso.

6. Quais os seus sentimentos em relação à capacidade de expressão em língua espanhola?

Fica, na verdade isso já é uma coisa sobre a qual eu já falei bastante, inclusive com o pessoal do curso, eles apresentam alguns argumentos que justificam essa dificuldade, argumentos inclusive sobre questão tecnológica, dificuldade de sistematizar e de organizar momentos e espaços para praticar essa oralidade, mas eu acho que, de fato, é uma negligência, então, fica uma sensação de que a gente não foi formado como deveria, já que seremos professores de língua; e não dá pra dissociar língua da escuta e da oralidade, de forma alguma.

7. Há alguma sugestão de atividade que você gostaria de ter realizado para desenvolvimento de sua oralidade?

$\mathrm{Na}$ verdade, sobre esse aspecto, inclusive, provavelmente meu TCC vai ser nessa área. Uma ideia de tentar, de alguma forma, trazer a oralidade para o ambiente da EAD. Acho que eles poderiam, por exemplo, ter proposto atividades em que o aluno pudesse gravar, sugeririam um tema, ou alguma coisa, dentro, claro, de uma organização, uma sistematização onde o aluno gravasse com o celular, alguma coisa, e enviasse esse arquivo e a gente tivesse um feedback sobre todos os aspectos, não só de fonética empregada, mas também léxico e coisas do tipo. Eu acho que sim, que a gente poderia ter tido atividades em que a gente poderia ou gravar ou ter um chat de voz, utilizando não só o sistema que tá disponível no Moodle, como utilizando também as próprias ferramentas gratuitas de Internet, como o Hangout, ou alguma coisa do tipo, que pudesse de fato ter permitido um pouco mais, aliás, permitido uma oralidade, porque na verdade não foi praticada.

Pra dizer que não, tivemos um, durante todo o curso tivemos uma atividade da disciplina de metodologia do ensino de espanhol, acho que foi sobre isso, em que a professora pediu que a gente gravasse um vídeo, selecionasse uma das metodologias e dos enfoques comunicativos, ou outros enfoques empregados e gravasse um vídeo em língua espanhola pra explicar; só que a gente não teve, até onde eu sei, eu mesmo não tive, acho que os colegas também, a gente não teve nenhum feedback em relação à oralidade. $\mathrm{O}$ feedback foi em relação ao conteúdo tratado. 


\section{João}

1. Qual tipo de conhecimento da língua espanhola você possuía ao ingressar no curso?

$\mathrm{Na}$ verdade nenhum. Eu fazia um curso quando entrei nesse. Era um curso de segurança no trabalho, mas antes de eu fazer segurança no trabalho eu estudava inglês. Foram 3 anos e meio amando estudar línguas, aí aproveitei para fazer espanhol.

2. Quais atividades realizadas nas disciplinas ajudaram a desenvolver a sua oralidade?

É bem complicado, é uma questão bem complicada, por conta da EAD, porque a gente não tem aula presenciais, nem se que uma por mês, que seria ideal, nos ajudaria. Então tem poucas atividades que trabalhem a oralidade; mas eu trabalho no PIBID. O PIBID a gente vai pra sala de aula mesmo, a gente vai dar aula pros alunos embora o nosso subprojeto não seja bem do espanhol, a gente trabalha com gêneros textuais, mas nós envolvemos o espanhol. A gente trabalha textos da língua espanhola, textos hispano-americanos.

[Atividades] Pra dizer que não, apenas uma. Somente o professor da matéria de mídias pediu pra gente gravar um áudio, mas não era avaliativo e a gente gravou por gravar. Ele não iria nos corrigir.

3. Como você classificaria hoje a sua capacidade de expressão oral em língua espanhola?

Muito deficiente. Não consigo me expressar em língua espanhola. No meu caso eu estou bem atrasado no curso, essa é a verdade. Estou no sétimo semestre, mas acabei de pagar língua espanhola IV, na verdade no próximo semestre não era para eu pagar nenhuma, mas ainda tenho que pagar a V; mas a gente vai procurando outros meios. São cinco matérias de espanhol, mas há outras também da área que a gente vai desenvolvendo o espanhol, mas bem deficiente.

4. Você se sente pronto para ministrar uma aula em língua espanhola?

Na verdade toda [a aula] em espanhol é complicado. Acredito que nem o professor já formado dá aula totalmente em espanhol. Tem a possibilidade de ir traduzindo e falando em português para ajudar o aluno; então acredito que dê para dar uma aula de língua espanhola. 
5. Quais as suas expectativas em relação à língua espanhola (principalmente na parte da oralidade) até o término do curso?

Buscando outros meios; por exemplo, até o Duolinguo pode ajudar; e outros eventos e outros cursos que vão aparecendo a gente vai participando. O PIBID mesmo vem ajudando e vai ajudar muito até terminar o projeto.

6. Quais os seus sentimentos em relação à capacidade de expressão em língua espanhola?

Sinceramente, eu não recomento $\mathrm{EAD}$, essa é a verdade; mas se você não tem outra alternativa, se você quer fazer, quer estudar na EAD, procurar outros meios de desenvolver a língua, a fala, a escrita... não se limitar só ao curso, somente à plataforma, no nosso caso o Moodle, mas ir procurando outros meios.

7. Há alguma sugestão de atividade que você gostaria de ter realizado para desenvolvimento de sua oralidade?

Aulas presenciais... na verdade uma vez por mês, ou de 15 em 15 dias, que é o que acontece com o curso da UFRN. Inclusive que acontece aqui na CEMURE; eles têm aula de mês em mês. [não é língua espanhola.] Quando nós "pagamos" Latim, a gente teve uma dificuldade enorme, a gente pedia e pedia uma aula ou outra com o professor e nunca conseguimos. É isso, uma aula ou outra para que na dificuldade a gente reverta a situação.

Eu quero entrar no mestrado. Eu não penso muito na área docente, eu quero trabalhar com tradução ou algo assim, mas não exatamente como professor.

[Nota de campo: esse estudante faz curso presencial de língua espanhola - licenciatura]

\section{Angélica}

1. Qual tipo de conhecimento da língua espanhola você possuía ao ingressar no curso?

Um conhecimento médio, não era muito não. Aí hoje já melhorou bastante. Tá melhorando...

2. Quais atividades realizadas nas disciplinas ajudaram a desenvolver a sua oralidade?

Ferramentas na Internet, Duolinguo... esses tipos de ferramenta. Atividade específica do curso não. 
3. Como você classificaria hoje a sua capacidade de expressão oral em língua espanhola? Ainda não está boa, mas está melhorando.

4. Você se sente pronto para ministrar uma aula em língua espanhola?

Não, hoje não me sinto pronta para dar uma aula toda em língua espanhola.

5. Quais as suas expectativas em relação à língua espanhola (principalmente na parte da oralidade) até o término do curso?

Melhorar minha fluência, falar... e o conhecimento da língua também.

6. Quais os seus sentimentos em relação à capacidade de expressão em língua espanhola? Tá tranquilo...

7. Há alguma sugestão de atividade que você gostaria de ter realizado para desenvolvimento de sua oralidade?

Encontros para treinar a língua. 